\title{
Punitive Civil Sanctions: The Middleground Between Criminal and Civil Law
}

\author{
Kenneth Mann†
}

\section{CONTENTS}

INTRODUCTION $\ldots \ldots \ldots \ldots \ldots \ldots \ldots \ldots \ldots \ldots \ldots \ldots \ldots \ldots \ldots$

I. The Paradigms of CiviL AND CRIMINAL LAW . . . . . . . . . . . 1803

A. Subjective vs. Objective Liability and Wrongful vs. Harmful Acts . . 1805

1. The Mental Element in Prohibited Acts . . . . . . . . . 1805

2. The Effects of Prohibited Acts ............... 1806

B. Purpose: Punishment vs. Compensation ... . . . . . . . . . 1807

C. Remedy: Stigma and Incarceration vs. Restitution and Monetary Payments ............................. 1809

D. Procedure: High vs. Low Certainty and State vs. Private Initiative 1810

1. Evidentiary Rules ..................... 1810

2. The Moving Party ..................... 1812

E. A Summary of Principal Paradigmatic Distinctions . . . . . . . . 1813

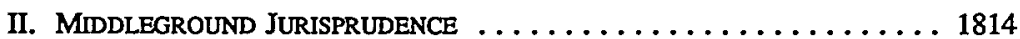

A. The Field of Inquiry . . . . . . . . . . . . . . . . . . . 1814

1. More-than-Compensatory Monetary Sanctions . . . . . . . 1815

2. The Problem ...................... 1816

B. Jurisprudential Approaches .................. 1816

1. The Punitive Approach ................. 1817

2. Formal Procedural Approach ............... 1820

3. Compensatory Approach .................. 1823

a. Tax Fraud ....................... 1826

b. False Claims on the Government ............ 1827

4. Deterrence Approach ................... 1830

a. Oceanic Steam Navigation Co. v. Stranahan ......... 1831

$\dagger$ Associate Professor, Faculty of Law, Tel-Aviv University. M.A., Center for the Study of Law and Society, Berkeley, 1974; J.D., Boalt Hall, 1975; Ph.D., Yale University, 1980.

I would like to thank Abraham Goldstein for many informative conversations and for his critical reading of several drafts. I also owe an intellectual debt to Stanton Wheeler at Yale and to Dr. Kurt Kanowitz of Israel. Others who provided important comments or assistance are Robert Blakey, Meir DanCohen, Owen Fiss, Daniel Freed, Irit Haviv-Segel, Judith Resnik, William Schwartz, John Simon, Aviam Soifer, Kate Stith, Ruth Wedgwood, and Franklin Zimring.

While writing, I was also supported by several institutions: first, during a sabbatical, by the Seth Boyden Visiting Professorship at the Law School and the School of Criminal Justice of Rutgers University, Newark, N.J., for which I thank Dean Peter Simmons and Dean Ron Clarke; later, as Senior Research Fellow in the Program on Civil Liability in Yale Law School, directed by George Priest; and finally, by the National Institute of Justice, U.S. Department of Justice, under contract OJP-89-C-009, with Abt Associates, Inc. The opinions stated in the Article do not necessarily reflect the positions or policies of the U.S. Department of Justice or of anyone else, except the author. 
b. Atlas Roofing Co. v. Occupational Safety and Health Review

Commission .......................... 1832

c. United States v. Ward ................. 1835

C. The Punitive Nature of More-than-Conpensatory Money Sanctions 1837

D. The Reemergence of the Punitive Approach . . . . . . . . . 1840

III. THE INCREASEd ROLE OF PUNITIVE CIVIL SANCTIONS EXPLAINED $\ldots . .1844$

A. The Changing Philosophy of Sanctioning ............ 1845

B. The General Expansion of Sanctioning . . . . . . . . . . 1847

C. The Growth of the Administrative State ............... 1849

D. Procedural Obstacles in the Criminal Process: The False Claims Act

as an Example ......................... 1853

1. The Decision to Indict and the Burden of Proof ........ 1853

2. Access to Evidence ....................... 1855

a. Civil Procedure in the Courts ............ 1855

b. Extending Procedural Reform: The False Claims Act ... 1859

IV. IMPLICATIONS OF THE GROWING ROLE OF PUNITIVE CIVIL SANCTIONS . 1861

A. Administrative Agency Prosecution . . . . . . . . . . . 1862

B. The Attenuated Role of Criminal Prosecution ........... 1863

C. Relationship Among Criminal, Punitive Civil, and Remedial Sanct-

ions ................................ 1864

1. Substantive Scope ...................... 1864

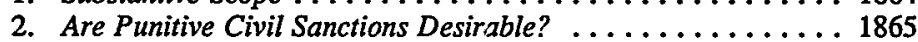

3. Parallel State-Invoked Punitive Sanctions . . . . . . . . 1866

4. Private Punitive Sanctions ................... 1868

5. A New Procedural Middleground? .................... 1869

ConcLUSION $\ldots \ldots \ldots \ldots \ldots \ldots \ldots \ldots \ldots \ldots \ldots \ldots \ldots \ldots \ldots \ldots \ldots \ldots \ldots \ldots$

\section{INTRODUCTION}

When harmed by another member of society, one assumes that two fundamentally different legal responses are at one's disposal-criminal sanctions and civil remedies. This view is reflected in Justice White's majority opinion in Hicks v. Feiock:

The States have long been able to plan their own procedures around the traditional distinction between civil and criminal remedies. The abandonment of this clear dividing line in favor of a general assessment of the manifold and complex purposes that lie behind a court's action would create novel problems where now there are rarely any-novel problems that could infect many different areas of the law. ${ }^{1}$

At the heart of this statement is the idea that the criminal law is meant to punish, while the civil law is meant to compensate. The criminal and civil law, each with different purposes and procedural rules, constitute paradigms by

1. Hicks v. Feiock, 485 U.S. $624,636-37$ (1988) (distinguishing between punitive sanctions imposed for past wrongful conduct and remedial sanctions levied to compel payment of child support). 
which legislatures and courts analyze their actions ${ }^{2}$ and by which textbooks and scholarly literature structure arguments. ${ }^{3}$ These paradigms shape both legal principles and the legal profession with respect to issues such as the specialization of attorneys, ${ }^{4}$ the definition of procedural rules, ${ }^{5}$ and the division of authority among courts. ${ }^{6}$

Though attractive to the legal mind, however, the bifurcation of legal sanctions into two categories is misleading. In numerous civil cases plaintiffs have sought punitive sanctions against defendants who were charged with serious wrongdoing. Under the False Claims Act, the United States government sought a punitive civil penalty of $\$ 130,000$ from an individual who filed $\$ 535$ in false claims; 7 under the Comprehensive Forfeiture Act of 1988, the First Circuit Court of Appeals compelled a man to give up 17.9 acres of property on which a home was situated after police seized 130 marijuana plants on the property; ${ }^{8}$ under the Racketeer Influenced and Corrupt Organizations Act (RICO), private plaintiffs filed suit for $\$ 10$ billion, mostly for punitive damages, against an electrical power company for fraud in overcharging; ${ }^{9}$ under common

2. See, for instance, the line of habeas corpus cases that determine which procedural rules apply by deciding whether the action is criminal or civil: Hilton v. Braunskill, 481 U.S. 770, 776 (1987) ("[G]eneral standards governing stays of civil judgments should also guide courts when they must decide whether to release a habeas petitioner pending the State's appeal . . ..."); Harris v. Nelson, 394 U.S. 286, 293-94 (1969) (observing that labeling habeas corpus proceedings as "civil" is "gross and inexact"); Fisher v. Baker, 203 U.S. 174, 181 (1906) (dismissing writ of error as improper proceeding because "[t]he proceeding is in habeas corpus, and is a civil and not a criminal proceeding").

3. See, e.g., Phillip E. Jolinson, CrIMINAl LaW (4th ed. 1990); SANFORD H. Kadish \& STEPHEN J. SchulHoFer, CRIMINAL LAW AND ITS PROCESSES (5th ed. 1989); WAYNE R. LAFAVE, MOdERN CRIMINAL LAW (2d ed. 1988). But see JOSEPH GOLDSTEIN ET AL., CRIMNAL LAW: THEORY AND PROCESS 253-317 (1974) (actually posing problem of distinguishing between civil and criminal cases). See generally GLANVILLE WILLIAMS, TEXTBOOK OF CRIMINAL LAW § 8, at 20 (1st ed. 1978) (mentioning that "[t]o some extent the civil law shares with the criminal law the aim of controlling conduct").

The literature on civil procedure rarely addresses the civil law's increasing concern with criminal conduct. An illuminating exception is ROBERT M. COVER ET AL., PROCEDURE (1988) (outlining fundamental questions of procedure that span civil, criminal, and administrative cases).

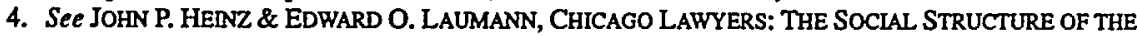
BAR 43 (1982) (explaining that criminal law is most specialized of all legal fields when measured by concentration of cases in attorneys' caseloads).

5. Compare FED. R. CrV. P. 1 ("These rules govern the procedure in the United States district courts in all suits of a civil nature whether cognizable as cases at law or in equity or in admiralty ....") with FED. R. CRMM. P. 1 ("These rules govem the procedure in all criminal proceedings in the courts of the United States .....").

6. See, e.g., N.Y. JuD. LAW $\$ 2$ (Consol. 1983) (providing that "[t]he civil court of the city of New York and the criminal court of the city of New York" are "court[s] of record"); N.Y. CRIM. PROC. LAW $\$ 10.10$ (Consol. 1986) ("The 'criminal courts' of this state are comprised of the superior courts and the local criminal courts."); N.Y. CIV. PRAC. L. \& R. \$ 106 (Consol. 1976) ("Where the violation of a right admits of both a civil and criminal prosecution, the one is not merged in the other.").

7. United States v. Halper, 490 U.S. 435 (1989).

8. United States v. 40 Moon Hill Road, 884 F.2d 41, 43 (1st Cir. 1989); see also United States v. 141st St. Corp., 911 F.2d 870, 880-81 (2d Cir. 1990) (holding Eighth Amendment not violated where real estate holding company was compelled to forfeit six-story building upon evidence of drug dealing by tenants), cert. denied, 111 S. Ct. 1017 (1991).

9. County of Suffolk v. Long Island Lighting Co., 710 F. Supp. 1407, 1418 (E.D.N.Y. 1989) (“[If plaintiffs are successful] LILCO [the defendant] will be forced into bankruptcy . . . ."); see also Summers v. Federal Deposit Ins. Corp., 592 F. Supp. 1240, 1242-43 (W.D. Okla. 1984) ("[T]reble damages under RICO are wholly disproportionate to the injury ... . [I]t appears on balance that they are . . . penal." 
law tort principles, a woman defrauded by an insurance company received an award of $\$ 840,000$ in punitive damages, more than four times her actual damage. ${ }^{10}$ Although these sanctions did not share the same basis of liability and were not ultimately imposed in all of the cases, each case affirmed the idea of punitive civil sanctions. ${ }^{11}$ The purpose of punitive civil sanctions is to punish, even though their procedural setting is civil.

While new criminal laws are appearing with great frequency and criminal sentences are growing more severe, punitive civil sanctions are rapidly expanding, affecting an increasingly large sector of society in cases brought by private parties as well as by the government. ${ }^{12}$ These sanctions are sometimes more severely punitive than the parallel criminal sanctions for the same conduct. ${ }^{13}$ Punitive civil sanctions are replacing a significant part of the criminal law in critical areas of law enforcement, particularly in white-collar and drug prosecutions, because they carry tremendous punitive power. Furthermore, since they are not constrained by criminal procedure, imposing them is cheaper and more efficient than imposing criminal sanctions. As a result, the jurisprudence of sanctions is experiencing a dramatic shift. With more punishment meted out in civil proceedings, the features distinguishing civil from criminal law become less clear. As civil law becomes more punitive, serious doubt arises about whether conventional civil procedure is suited for an unconventional civil law. ${ }^{14}$

(citations omitted)).

10. Pacific Mut. Life Ins. Co. v. Haslip, 111 S. Ct. 1032 (1991) (holding punitive damage award does not violate 14th Amendment).

11. The first two cases are examples of state-invoked punitive civil sanctions; the second two are examples of privately invoked punitive civil sanctions.

12. This Article assesses only federal law, but states have also increased the use of civil penalties. See, e.g., DEL. CODE ANN. tit. 5, $\$ 3355$ (Supp. 1990) (civil penalty up to $\$ 10,000$ for each violation and $\$ 10,000$ per day for continuing violations, assessed by commission under state administrative procedure act); ILL. ANN. STAT. ch. 17, para. 7311-6 (Smith-Hurd 1991) (civil penalty of up to $\$ 10,000$ for each violation of the statute, assessed by commissioner); MD. FIN. INST. CODE ANN. \& 12-508 (1986) (penalty of up to $\$ 1,000$ for each violation of subtitle, assessed by bank commissioner); N.Y. Bus. CORP. LAW $\S 1605$ (Consol. Supp. 1991) (civil penalty of $\$ 1000$ for individuals and $\$ 10,000$ for corporations for each violation of security takeover disclosure law).

13. The Insider Trading Sanctions Act of 1984, 15 U.S.C. \& 78u-1(a)(2) (1988), for instance, provides a civil penalty equivalent to three times the profit made or the loss avoided on a trade that utilized inside information illegally. A defendant might prefer a criminal conviction, with a short prison sentence, over such a stiff civil penalty. $C f$. One 1958 Plymouth Sedan v. Pennsylvania, 380 U.S. 693 (1965) (civil forfeiture more severely punitive than criminal penalty for same conduct).

14. The sharp increase in the number of civil proceedings used to sanction essentially criminal conduct has caused growing concern about deprivations of due process. It has stimulated inquiry into punitive civil sanctions to determine the type of procedure to apply to them. See Jonathan I. Chamey, The Need for Constitutional Protections for Defendants in Civil Penalty Cases, 59 CoRNELL L. REV. 478 (1974); Mary M. Cheh, Constitutional Limits on Using Civil Remedies to Achieve Criminal Law Objectives: Understanding and Transcending the Criminal-Civil Law Distinction, 42 HASTINGS L.J. 1325 (1991) (exploring differences between criminal and civil cases and recommending increased procedural protections for punitive civil sanctions); J. Morris Clark, Civil and Criminal Penalties and Forfeitures: A Framework for Constitutional Analysis, 60 MINN. L. REV. 379 (1976) (suggesting Court has not developed jurisprudence to determine why certain sanctions should trigger constitutional protections); Elizabeth S. Jahncke, United States v. Halper, Punitive Civil Fines, and the Double Jeopardy ana' Excessive Fines Clauses, 66 N.Y.U. L. REV. 112, 142 (1991) (arguing that Court did not go far enough in protecting defendants from excessive punishment); Tamara R. Piety, Comment, Scorched Earth: How the Expansion of Civil Forfeiture Doctrine 
I use the term "middleground" to describe the jurisprudential arena of punitive civil sanctions. ${ }^{15}$ The middleground draws on the two basic paradigms that form the doctrinal basis for the entire field of sanctioning law: criminal law and civil law. The paradigms of criminal and civil law stem from longstanding conventions about the essential nature and function of legal sanctions. Within this paradigmatic framework the criminal law is distinguished by its punitive purposes, its high procedural barriers to conviction, its concern with the blameworthiness of the defendant, and its particularly harsh sanctions. In contrast, the civil law is defined as a compensatory scheme, focusing on damage rather than on blameworthiness, and providing less severe sanctions and lower procedural safeguards than the criminal law. The middleground draws on these two basic paradigms to form a hybrid jurisprudence in which the sanction's purpose is punishment, but its procedure is drawn primarily from the civil law.

While the middleground includes both state-invoked and privately invoked proceedings, these punitive sanctions rest on different assumptions. ${ }^{16}$ The privately invoked sanction derives from the common law right of the jury to award exemplary damages, and is thus doctrinally circumscribed by little other than the concept of discretion uninfluenced by corrupt motive. The stateinvoked sanction, on the other hand, is rooted in the sovereign's prerogative and police power, and thus prompts suspicion of state power and questions about the need for special procedural doctrines to protect the citizen from

Has Laid Waste to Due Process, 45 U. MIAMI L. REv. 911 (1991).

15. Middleground sanctions include any form of legal process that combines elements of both civil and criminal law. Two types of middleground sanctions exist: punitive sanctions in civil procedural settings and remedial sanctions in criminal procedural settings. This Article deals with the former. On remedial purpose in criminal proceedings, see Abraham S. Goldstein, Defining the Role of the Victim in Criminal Prosecution, 52 Miss. L.J. 515, 521 (1982) ("Restitution [in the criminal process] came into vogue in the United States ... in the late nineteenth and early twentieth centuries as part of the increasing emphasis on rehabilitation ... . "); Note, Restitution and the Criminal Law, 39 COLUM. L. REV. 1185 (1939); Lawrence P. Fletcher, Note, Restitution in the Criminal Process: Procedures for Fixing the Offender's Liability, 93 YALE L.J. 505 (1984).

16. Justice O'Connor recently emphasized this close connection between punitive damages, civil penalties, and criminal punishment in her dissent in Browning-Ferris Industries v. Kelco Disposal, Inc., 492 U.S. 257 (1989). In assessing the applicability of the Excessive Fines Clause of the Eighth Amendment to punitive damages, the majority of the Court found that the word "fine" connoted a money penalty imposed by the King only, that is, by governmental authority, not by a private party, and therefore the Eighth Amendment could not be applied to punitive damages sought in a private civil suit. Id. at 266-68. The majority recognized that damages sometimes have a punitive purpose but found that the nature of the moving party, not the purpose of the sanction, triggered the Excessive Fines Clause. Id. at 257. The dissent argued that the purpose of the sanction brings the clause into play. Joined by Justice Stevens, Justice O'Connor wrote:

In my view, a chronological account of the Clause and its antecedents demonstrates that the Clause derives from limitations in English law on monetary penalties exacted in civil and criminal cases to punish and deter misconduct. History aside, this Court's cases leave no doubt that punitive damages serve the same purposes-punishment and deterrence-as the criminal law, and that excessive punitive damages present precisely the evil of exorbitant monetary penalties that the Clause was designed to prevent.

ld. at 287 ( $\mathrm{O}$ 'Connor, J., dissenting). 
overreach and unreasonableness. ${ }^{17}$ This Article focuses mainly on state-imposed punitive civil sanctions-that is, punitive sanctions in which the government, usually an administrative agency, is the moving party. Although the government has long possessed the power to impose sanctions that do not fit into the conventional paradigms of civil and criminal law, the differentiation of legal sanctions into two groups created a false dichotomy even before punitive civil sanctions became commonplace.

The distinction between criminal and civil law has continued to shape the jurisprudence of sanctions, creating a framework for case law and legislative policy. Particularly, given the rapid growth of punitive civil sanctions, one must conclude that either (1) the paradigms have been wrongly defined and have therefore produced an incorrect understancling of the law, or (2) courts and legislatures have wrongly allowed the development of sanctions that do not incorporate the values of the civil and criminal paradigms. ${ }^{18}$ These issues have become more pressing because of the controversy surrounding the allegedly growing use of punitive damages in tor ${ }^{19}$ and the increasing congressional willingness to allow citizens to act as private attorneys general to bring punitive civil proceedings in the name of the state ${ }^{20}$ or in place of the state. ${ }^{21}$

17. For a striking illustration of the vast reach of new forms of punitive civil sanctions and the breach of conventional boundaries around forms of legal redress, consider the Georgia legislature's attempt to convert the private action for punitive damages in product liability actions into a joint private and state action, allowing the state to collect $75 \%$ of any punitive damages awarded in the private case. This would essentially have been a reverse qui tam action, with the government taking over part of a private cause of action. (In qui tom actions, the private party takes over part of the government's cause of action.) The statute was struck down as unconstitutional in McBride v. General Motors Corp., 737 F. Supp. 1563, 1578 (M.D. $\mathrm{Ga}$. 1990) (noting that statute would "convert!] the civil nature action of the prior Georgia punitive damages statute into a statute where fines are being made for the benefit of the State," violating both the Excessive Fines and Double Jeopardy Clauses).

18. Years ago, Herbert Packer decried the absence of a theory of sanctions, while developing a set of principles for limiting the scope of the criminal sanction in the larger context of sanction types. HERBERT L. PACKER, THE LIMTS OF THE CRIMINAL SANCTION 251 (1968). Packer did not, however, develop a significant role for punishment outside of the criminal law. Therefore, he did not deal with the growing phenomenon of punitive sanctions in civil law settings.

19. Pacific Mut. Life Ins. Co. v. Haslip, 111 S. Ct. 1032, 1066 (1991) (O'Connor, J., dissenting). "In the past, such awards [of punitive damages] 'merited scant attention' because they were 'rarely assessed and likely to be small in amount.' . . Recent years, however, have witnessed an explosion in the frequency and size of punitive damage awards." Id. (citation omitted). Deploring what she described as an unjustified growth in punitive damage awards, Justice O'Connor continued: "Within nine months of our decision in Browning-Ferris, there were no fewer than six punitive damages awards of more than $\$ 20$ million." Id.

20. This objective is accomplished principally through qui tam actions. The qui tam action authorizes private parties to bring government enforcement proceedings in a representative capacity. The private party sues in the name of the United States and receives part of the money judgment that otherwise would go to the government. The monetary incentive for the private plaintiff is often strong and works successfully to encourage the disclosure of wrongdoing. See, e.g., False Claims Act, 31 U.S.C. $\$ 3729$ (1988). False claims presented by government contractors have led to large qui tam claims by insiders in the defense industry. Generally, it is believed that the qui tam incentive is successful in facilitating enforcement actions that otherwise would not be brought. See Valerie R. Park, Note, The False Claims Act. Qui Tam Relators, and the Government: Which is the Real Party to the Action?, 43 STAN. L. REv. 1061 (1991) (increased awards to private plaintiffs under False Claims Act have generated numerous suits and strengthened law enforcement). 
At the same time, Congress has also enlarged existing powers and provided new authority to administrative agencies to punish offenders in civil proceedings. ${ }^{22}$ While legislatures and courts have busily created punitive civil sanctions for the state to impose, they have gone to great lengths to avoid labeling them as "punitive" to circumvent the application of criminal-type procedural rules. In many instances, the very motivation for the creation of civil punitive sanctions was to avoid criminal procedural protection. ${ }^{23}$

21. The RICO statute provides a cause of action for private plaintiffs to sue and obtain money judgments of three times the damage caused. See 18 U.S.C. \& 1964(c) (1988). This act has been used mainly by legitimate businesses against other legitimate businesses for causes of action in fraud. See H.J. Inc. v. Northwestern Bell Tel. Co., 492 U.S. 229 (1989) (Congress wanted to reach both "legitimate" and "illegitimate" enterprises under RICO); Sedima, S.P.R.L. v. Imrex Co., Inc., 473 U.S. 479, 495 (1985) (RICO applicable to legitimate business); United States v. Turkette, 452 U.S. 576, 591 (1981) (Congress wanted to reach legitimate as well as illegitimate enterprises); G. Robert Blakey, Foreword, 65 NOTRE DAME L. REV. 873, 878-79 (1990) (RICO created private enforcement mechanism for facilitating detection of violations). See generally Symposium, Law and the Continuing Enterprise: Perspectives on RICO, 65 NOTRE DAME L. REV. 873 (1990). In 1985, the American Bar Association found that of the then-known civil RICO cases, $40 \%$ involved securities fraud and $37 \%$ involved common law fraud in a commercial context, while only 9\% involved "allegations of criminal activity of a type generally associated with professional criminals." Report of the Ad Hoc Civil RICO Task Force, 1985 A.B.A. SEC. CORP., BANKING \& BUS. L. 55-56.

22. See, e.g., Financial Institutions Reform, Recovery, and Enforcement Act of 1989 (FIRREA), Pub. L. No. 101-73, 103 Stat. 183 (codified as amended in scattered sections of 12 U.S.C.). FIRREA was passed in the wake of the nationwide collapse of the savings and loan industry. It authorizes a three-tier system of administrative penalties applicable to certain regulated institutions. For example, for depository institutions regulated by the FDIC, an ordinary violation carries a maximum penalty of $\$ 5000$ per day, 12 U.S.C. $\$$ $1818(i)(2)(A)$ (1988 \& Supp. I 1989); this ceiling rises to a maximum penalty of $\$ 25,000$ per day if the institution "recklessly engages in an unsafe or unsound practice," or breaches any fiduciary duty, when such "violation, practice, or breach" is "part of a pattern of misconduct," "causes or is likely to cause more than a minimal loss," or "results in pecuniary gain or other benefit to [the institution or institution-affiliated partyl," 12 U.S.C. $\$ 1818(i)(2)(B)$; the penalty goes up to $\$ 1,000,000$ or one percent of the total assets of an institution (whichever is less) if the institution knowingly engages in any such violation, practice, or breach and "knowingly or recklessly causes a substantial loss" or benefit to an institution as a result of such acts, 12 U.S.C. \& 1818(i)(2)(C)-(D). Other institutions are subject to equivalent three-tiered penalties. These penalties are applied through administrative assessment and upon requested agency hearing. See, e.g., 12 U.S.C. $\$ 1818$ (i)(2)(E). FIRREA also provides for a judicially imposed civil penalty of $\$ 1,000,000$ per day up to a maximum of $\$ 5,000,000$ for any continuing violation of sections of the U.S. Criminal Code relating to banks. 12 U.S.C. $\$ 1833$ a(b). FIRREA's net result is that administrative civil penalties and judicial civil penalties may apply to the same conduct of banks and bank officers.

In addition to FIRREA; the Insider Trading Sanctions Act of 1984, 15 U.S.C. $\$ 78$ u-1 (1988), authorizes courts to impose a threefold civil money penalty on both the person committing the violation and any controlling person. The Securities Enforcement Remedies and Penny Stock Reform Act of 1990, 15 U.S.C.A. $\$ \$ 77 \mathrm{~g}, 78 \mathrm{u}, 78 \mathrm{u}-2$ (West Supp. 1990), authorizes the SEC to seek a judicially enforced civil penalty of up to $\$ 100,000$ against a natural person or $\$ 500,000$ against an entity for any violation of any provision of the Securities Act of 1933, 15 U.S.C. §§ 77a-77aa (1988), or the Trust Indenture Act of 1939, 15 U.S.C. $\$ \$ 77 \mathrm{aaa}-77 \mathrm{bbbb}$ (1988); the SEC can impose similar civil penalties in administrative proceedings for certain violations.

See also 21 U.S.C. $\$ 881$ (a) (1988) (permitting forfeiture of real property that facilitates drug offenses); 31 U.S.C. $\$ \$ 3729,3802$ (1988) (establishing federal false claims triple damage penalty and per offense penalty of $\$ 10,000-$ which is added to multiple damage penalty-while creating administrative penalty of double damages plus up to $\$ 5000$ for each offense); 42 U.S.C. $\$ 1320 \mathrm{a}-7 \mathrm{a}$ (1988) (authorizing Department of Health and Human Services to impose civil penalty of up to $\$ 15,000$ per offense, in addition to twice amount claimed, for claims involving submission of false information).

23. See, e.g., Smith v. Department of Human Servs., 876 F.2d 832, 836 (10th Cir. 1989) (purpose of liquidated damages provision in Age Discrimination in Employment Act (ADEA) was to avoid "anticipated difficulties of proof under a criminal provision, as well as impediments to investigation, conciliation, and enforcement that might arise from an employer's invocation of the fifth amendment, the criminal penalty 
The growth of state-invoked and privately invoked punitive civil sanctions raises critical questions for current and future sanctions for illegal behavior. When should law enforcement agencies choose criminal sanctions over punitive civil sanctions? What is the role of full-fledged criminal sanctions in a legal system increasingly characterized by punitive civil sanctions? If a process labeled "civil" metes out punitive sanctions, should criminal-type procedural protections apply? How much can the "punitiveness" of sanctions imposed in civil proceedings be increased to strengthen law enforcement tools without turning to the criminal law? Is there a proper place for parallel proceedingsone private and one brought by the state-seeking punitive sanctions against the same person or entity for the same conduct? Should legislation encourage private punitive proceedings to take an increasingly large part of the law of sanctions out of the hands of the state?

Part I details the conventional paradigms of criminal and civil law. Part II conceptualizes the parameters of the middleground, mainly focusing on stateinvoked, punitive civil monetary sanctions. A main theme of this material is the Supreme Court's use of legal fictions in describing punitive civil sanctions to avoid the procedural implications of punitiveness, particularly the creation of high procedural barriers to imposing sanctions. With these fictions, the Court has suppressed the development of distinctive procedural rules for middleground sanctions.

Part III focuses on the reasons behind the accelerating growth of punitive civil sanctions. The causes are complex and include the growing influence of utilitarianism and deterrence theory in the law, the general expansion of law and litigation, the increasing authority of administrative agencies, frustration with the procedural obstacles of the criminal law, and reforms in civil procedure.

Part IV discusses the implications of middleground jurisprudence. First, I suggest increasing both the size and frequency of punitive civil monetary sanctions. This would have the major benefit of decreasing the use of the criminal law, confining it to areas of clearly egregious behavior in which severely punitive civil monetary sanctions are ineffective. Thus, I advocate the shrinking of the criminal law in order to fit it into its proper role in the law of sanctions, next to an expanding arena of punitive civil sanctions.

Second, I add my voice to those who have argued that the procedure with which punitive civil sanctions are imposed fails to properly protect substantive and procedural due process values and that the future use of such sanctions, should they grow in size, may subvert these values if no independent middleground procedure is developed. I expand on this argument by connecting changes in state-invoked punitive civil sanctions to the development of privately

for willful violations," specifically, "to provide an effective deterrent to willful violations of the ADEA." (citations omitted)); $c f$. Trans World Airlines, Inc. v. Thurston, 469 U.S. 111, 125 (1985) (liquidated damages under ADEA are punitive). 
invoked sanctions, both of which present the problem of finding a correct procedural form.

\section{The Paradigms of Civil and Criminal LaW}

To grasp the significance of the conventional paradigms for the development of the law of sanctions, it is essential to note that early English and American judges and commentators adopted a language fraught with bipolar images of the law of sanctions. They wrote about the "criminal law" and the "civil law" in spite of the fact that middleground sanctions, such as punitive damages in tort, always existed. ${ }^{24}$ The law of sanctions theoretically recognized only two paradigms of legal ordering, when in fact the actual sanctioning forms contained a substantial variation of substantive definitions, purposes, remedies, and procedures.

Describing the law of the fourteenth and fifteenth centuries, Holdsworth observed that it was "in this period that the foundations of our present law as to Wrongs criminal and civil [were] laid."25 The differences apparently became quite well entrenched. In 1776 Lord Mansfield said, "Now there is no distinction better known, than the distinction between civil and criminal law; or between criminal prosecutions and civil actions. ${ }^{.26}$ Out of this historic division between the two main categories of legal process emerged the deeply ingrained language distinguishing criminal penalties from civil remedies. ${ }^{27}$ These terms reflected the development of a dominant ideology, clustering the different traits of legal sanctions together to create important normative focal points in jurisprudence $:^{28}$ the criminal and civil law paradigms. ${ }^{29}$ Thus, a sanction may be

24. The use of bipolar concepts to describe empirical facts that do not fit well into only two categories has continued over a prolonged period. It is a form of overgeneralization that speaks to the need for order more than it presents an accurate description of the field of sanctions.

25. 3 WILLIAM HOLDSWORTH, A HISTORY OF ENGLISH LAW 276 (reprint 1977) (5th ed. 1942).

26. Atcheson v. Everitt, 98 Eng. Rep. 1142, 1147 (27 K.B. 1775) (emphasis added); see also infra notes 86-88 and accompanying text.

27. Civil and criminal law are both sanctioning processes. In its broadest and most neutral sense, the term "sanction" implies not the imposition of punishment, but rather the use of power to determine rights that necessarily constrain behavior. English legal historians used the term in this way. According to Holmes, for example, Austin regarded the "[civil] liability to an action as a sanction." OLIVER W. HOLMES, JR., THE COMMON LAW 82 (Boston, Little, Brown \& Co. 1881); see also PACKER, supra note 18, at 23 (describing sanctions as "those rules of the legal order that prescribe the consequences of violating the primary norms that are meant to govem behavior"). Packer defines four types of sanctions: punishment, treatment, compensation, and regulation. Id. at 23-31.

Generally the term "remedy" is associated only with civil cases. $C f$. DAN B. DOBBS, HANDBOOK ON THE LAW OF REMEDIES $\S 1.1$ (1973). Dobbs implies that punishment is not a remedy. Id. $\S 1.1$, at 1 .

28. The leading article on fundamental differences between civil and criminal law is Jerome Hall, Interrelations of Criminal Law and Torts (pts. 1 \& 2), 43 CoLUM. L. REV. 753, 967 (1943). Hall reviews much of the relevant writing on the subject, contrasting with his own position Bentham and Austin, who found almost no differences between criminal and civil law, and Holmes, who minimized the differences. Drawing on Blackstone and Stephen, Hall argues that there have always been fundamental distinctions between the two forms of law and focuses mainly on the concepts of "social harm" and "morally culpable conduct" in the criminal law, as opposed to "individual harm" and objective responsibility in tort. See, e.g., $i d$, at 974. 
viewed within the criminal law paradigm as a penalty, or within the civil law paradigm as a remedy.

The criminal and civil paradigms attempt to abstract a set of traits from the complex and multifaceted nature of sanctions, in which substantial areas of overlap exist between civil and criminal law. Almost every attribute associated with one paradigm appears in the other. Imprisonment, associated with the criminal process, also exists in the civil arena; civil contempt, for example, is punishable by incarceration. Payment of money, distinctively associated with civil law, takes the form of fines in the criminal law. The paradigms misrepresent the field of actual legal processes because they ignore a large variety of hybrid sanctions. In particular, they fail to identify the central role of punitive civil sanctions in the broader arena of legal sanctions.

In many instances, the correlation of an attribute with its paradigmatic context is an empirically valid reflection of the attribute's primacy in one paradigm rather than the other. In other instances, the paradigmatic co-option of attributes stems from historical conventions that are now eclipsed, and thus the paradigms contradict the actual development of attributes in sanctioning arrangements. This is precisely the case with punitive sanctions, which are paradigmatically associated with the criminal law, but now characterize so much of the civil law that punishment no longer seems a distinctive attribute of the criminal law..$^{30}$ The paradigms continue to be used widely, however, because they seem to capture what legal minds consider distinctive features of the law of sanctions.

In discussing the particular nature of the civil and criminal paradigms, it is assumed that as with every system of sanctions there must be definitions of wrongs, purposes, procedures, and remedies. This part reveals the generic aspect of these dimensions by examining the different characteristics found in the criminal and civil paradigms. The following analysis focuses on criminal law

29. The term "paradigm" indicates a set of norms, abstracted from specific factors to form a model. This Article uses the term in a manner close to that of Weber's definition of ideal type:

An ideal type is formed by the one-sided accentuation of one or more points of view and by the synthesis of a great many diffuse, discrete, more or less present and occasionally absent concrete individual phenomena, which are arranged according to those one-sidedly emphasized viewpoints into a unified analytical construct (Gedankenbild). In its conceptual purity, this mental construct (Gedankenbild) cannot be found empirically anywhere in reality. It is a utopia.

MAX WEBER, THE METHODOLOGY OF THE SOCIAL SCIENCES 90 (Edward A. Shils \& Henty A. Finch trans. \& eds., 1949) (emphasis omitted). The abstracted, one-sided accentuation is present in the paradigm, but the paradigm, unlike the ideal type, does not necessarily represent a utopia.

30. Despite their differences, civil and criminal law share important attributes at a high level of abstraction. Like other sanctioning systems, such as schools, clubs, or families, they facilitate and protect a determinate social order. For an incisive article on the cornection between law and other forms of social control, see Franklin Zimring \& Gordon Hawkins, The Legal Threat as an Instrument of Social Change, in LAW, JUSTICE, AND THE INDIVIDUAL: PSYCHOLOGICAL IND LEGAL IsSUES 60 (June L. Tapp \& Felice L. Levine eds., 1977) (assessing interaction between law and custom as different instruments of social control, and treating law's content as function of variable commitment to custom). However, as legal sanctioning systems, civil and criminal law are distinguishable from other sanctioning systems because their obligatory norms are enacted by institutions with a particular legal competence-democratically elected legislatures and constitutionally legitimated courts-that imbues them with authority and legitimacy. 
(the statutory law defining public norms) and the common law of torts rather than on contract law (the law of private norms). ${ }^{31}$

\section{A. Subjective vs. Objective Liability and Wrongful vs. Harmful Acts}

Any sanctioning system must define the wrongs to which its sanctions may be applied. Two features of prohibited acts are prominent in distinguishing the paradigms: the mental element required and the effect produced. ${ }^{32}$

\section{The Mental Element in Prohibited Acts}

In paradigmatic criminal law, commission of a wrongful act must be accompanied by a mental element of wrongdoing: mens rea, or subjective liability. ${ }^{33}$ This is a distinctive aspect of criminal law deeply rooted in English legal sources and generally not required for imposition of civil liability.

Since the middle of the thirteenth century, English law has emphasized heavily the mental element required in the criminal law. "[Y]our state of mind," said Bracton, "gives meaning to your act, and a crime is not committed unless the intent to injure (nocendi voluntas) intervene, nor is a theft committed except with the intent to steal." 34 The special mental element required in criminal law also runs through much of the American writing on the subject. For example, Bishop stated that "[t]he doctrine which requires an evil intent lies at the foundation of public justice." 35

While criminal law and civil law are similar in that both require voluntary acts, civil law depends principally on the notion of objective liability, either

31. The problems addressed in this part are also found in contract law, in which there is growing concern with punitive sanctions as a remedy for bad faith bargaining and breach. See infra note 91 .

32. This dimension of the paradigms deals with only two of the many elements that define the full range of prohibited conduct in the substantive law of wrongs. Definitions of conduct also vary as to whether an omission and/or an act satisfy their legal requirements, and as to whether special circumstances must exist that characterize the wrongdoer or the injured party.

33. Crimes of strict liability and negligence are deviant forms from the normative perspective of the paradigms. Their deviant characteristics rose out of the dominant role of the paradigms.

34. HenRY BRACton, DE Legibus 101b, quoted in Francis B. Sayre, Mens Rea, 45 HARV. L. Rev. 974, 985 (1932). Professor Sayre supported this view: "Furthermore, the intent of the defendant seems to have been a material factor, even from the very earliest times, in determining the extent of punishment. It was manifestly unjust that the man who accidentally killed with no intention of doing harm should suffer the extreme penalty of death." Sayre, supra, at 981-82.

Holdsworth, too, stated that the mental element distinguished criminal from civil liability. "[I]t is just the presence or absence of this element of wrongful intention which differentiates felony from trespass. It is taken as one of the tests-perhaps the chief test-which distinguishes criminal from civil liability." 3 HOLDSWORTH, supra note 25 , at 374 .

35. JOEL P. BISHOP, 1 COMMENTARIES ON THE CRIMINAL LAW $\$ 287$, at 171 (Boston, Little, Brown \& Co., 7th rev. ed. 1882); see also Morissette v. United States, 342 U.S. 246, 250 (1952) ("The contention that an injury can amount to a crime only when inflicted by intention is no provincial or transient notion."). For an economic interpretation of the intent requirement in criminal law, see Kenneth G. Dau-Schmidh $A n$ Economic Analysis of the Criminal Law as a Preference-Shaping Policy, 1990 DUKE L.J. 1, 38 ("[T]he intentional infliction of proscribed harms indicates deviant preferences in need of modification."). 
disregarding the mental element in conduct or requiring only negligence. The civil law imposes a sanction when there is "a failure to live up to an ideal standard of conduct which may be beyond the knowledge or capacity of the individual, and in acts which are normal and usual in the community, and without moral reproach in its eyes." ${ }^{36}$ Negligence gradually increased in importance in the law of torts after the seventeenth century. ${ }^{37}$

\section{The Effects of Prohibited Acts}

A second paradigmatic difference in the key elements of wrongful conduct concerns the effect of the act to which the sanction applies. Within the criminal paradigm, wrongful acts are sanctioned because they are public wrongs, violating a collective rather than an individual interest. ${ }^{38}$ The criminal sanction will apply even if no individual interest has suffered direct injury. The paradigmatic civil sanction, on the other hand, applies to conduct that causes actual damage to an individual interest; this is generally a prerequisite to civil liability. Thus, Holdsworth wrote, "a private person cannot sue civilly unless he can show a special grievance, whereas the king can lay the charge generally; a suit by a private person sounds in damages, whereas a suit by the king ends in the punishment of the guilty party. ${ }^{39}$ This distinction between private and public

36. WILlIAM L. PROSSER, HANDBOOK OF THE LAW OF TORTS $\$ 4$, at 22 (5th ed. 1984) (footnotes omitted). Empirically, as opposed to pardigmatically, civil and criminal law overlap. Civil law includes causes of action for intentional acts; criminal law includes strict and negligent liability. Therefore, no true empirical difference exists between civil and criminal law with respect to the range of mental states resulting in liability. However, most criminal cases require proof of subjective and objective liability, whereas most civil cases require proof only of objective liability. Therefore, we say that the paradigmatic task of the civil law is to compensate for damages caused in the normal corduct of everyday life, usually without regard to actual knowledge or intent. Thus, the distinctive character in the division in the paradigms lies in the requirement of attention to the subjective state of mind in the conventional criminal type.

37. According to Baker,

[t]he negligence approach of the modern law determines liability by focusing on the quality of the defendant's act rather than on the kind of harm done to the plaintiff. The rearrangement of so much of the modern law of tort around the concept of negligence is partly a result of that shift of focus. But there is nothing modern about the concept of negligence in itself; what has changed is its primacy.

JOHN H. BAKER, AN INTRODUCTION TO ENGLISH LEGAL HISTORY 455 (3d ed. 1990) (footnotes omitted). See generally George L. Priest, The Invention of Enterprise Liability: A Critical History of the Intellectual Foundations of Modern Tort Law, 14 J. LEGAL STUD. 461, 465-83 (1985) (tracing historical and intellectual evolution of tort liability). Although there were cases exhibiting all the characteristics of negligence long before the 19 th century, it was not until then that the term negligence was used to describe a separate cause of action. See generally Charles O. Gregory, Trespass to Negligence to Absolute Liability, 37 VA. L. REV. 359 (1951); Percy H. Winfield, The History of Negligence in the Law of Torts, 42 L.Q. REV. 184 (1926).

38. See, e.g., Jules L. Coleman, Crime, Kickers, and Transaction Structures, in NOMOS XXVII: CRMMINAL JUSTICE 313, 323 (J. Roland Pennock \& John W. Chapman eds., 1985) (observing that "key moral notions of criminal responsibility - of guilt and fault-are simply absent from the economic infrastructure"). But see Guido Calabresi \& A. Douglas Melamed, Property Fiules, Liability Rules, and Inalienability: One View of the Cathedral, 85 HARV. L. REV. 1089, 1124-27 (1972); Alvin K. Klevorick, Legal Theory and the Economic Analysis of Torts and Crimes, 85 COLUM. L. REV. 905, 908 (1985). For a critique of Klevorick, see George P. Fletcher, A Transaction Theory of Crime?, 85 COLUM. L. REV. 921, 925 (1985) (characterizing Klevorick's transaction theory of criminal sanctions as "narrow").

39. 2 HoLDSWORTH, supra note 25 , at 453 (footnotes omitted). 
injury was prevalent in early Anglo-American law and provided the basis for Blackstone's classification of law. ${ }^{40}$

The generalizations accurately describe distinctive correlations between characteristics of wrongs subject to sanctions and the sanctioning paradigm in which they are found. Jerome Hall put the difference this way: "[I]n torts, 'effects' almost invariably include actual damage to some person, whereas in crimes, damage is not essential-instead the notion of a 'social harm,' supplies the requirement there. ${ }^{\$ 41}$

\section{B. Purpose: Punishment vs. Compensation}

A second generic dimension that distinguishes paradigmatic civil and criminal law is purpose. Purpose defines the reason or motivation for constructing and using a sanctioning system. ${ }^{42}$ We are accustomed to saying that the purpose of the criminal law, in its most general sense, is control of antisocial behavior. But, historically, there have been different emphases in defining the purposes of criminal law, particularly with respect to the role of retribution in the criminal system. Retribution is not necessarily derived from or part of a theory of social control, for in the Kantian sense retribution is not justified or explained by any notion of utility. Punishment in the criminal law, then, can be understood as either a retributive and completely nonutilitarian act or as a means to achieve social control.

In modern legal theory the criminal and civil law share the purpose of social control; however, in the conventional paradigms, which predate the modern overlapping of the civil and criminal law, it was inappropriate to label the civil law as an instrument of social control. Before the language of the social sciences infused the law of sanctions, only criminal law was associated with punishment, both as a form of vengeance and as an instrument for protecting the public. ${ }^{43}$

\section{According to Blackstone,}

[w]rongs are divisible into two sorts or species: private wrongs, and public wrongs. The former are an infringement or privation of the private or civil rights belonging to individuals, considered as individuals; and are thereupon frequently termed civil injuries: the latter are a breach and violation of public rights and duties, which affect the whole community, considered as a community; and are distinguished by the harsher appellation of crimes and misdemeanors.

3 WILLIAM BLACKSTONE, COMMENTARIES *2.

41. Hall, supra note 28 , at 969 (footnote omitted).

42. Purpose is sometimes confused with remedy and in many instances may bear the same name. For instance, incapacitation has often been described as the purpose of a sanctioning system, although it is more properly classified as a means to an end. It can be used as a means to achieve deterrence, punishment, or compensation. The problem of distinguishing means and ends is most palpable in the law of contempt. See, e.g., Gompers v. Bucks Stove \& Range Co., 221 U.S. 418, 441-42 (1911) (distinguishing civil and criminal contempt).

43. On the purposes and justifications for punishment, see generally FRANCIS A. ALLEN, THE BORDERLAND OF CRIMINAL JUSTICE 25-41 (1964) (explaining rehabilitative ideal); H.L.A. HART, PUNISHMENT AND RESPONSIBLTY 1-27 (1968) (defending mixed theory combining retributivist and utilitarian elements); Johannes Andenaes, General Prevention-Illusion or Reality?, 43 J. CRIM. L., CRIMINOLOGY \& POLICE SCI. 
Substantial normative disagreement has long characterized the debate about the primary justification for the criminal sanction. ${ }^{44}$ Yet despite the different emphases and the evolution of different philosophies on this central issue, most would agree that either as a means or an end, punishment is a distinctive, i.e., paradigmatic, characteristic of the criminal law, even though it is not exclusive to it. ${ }^{45}$ The convicted defendant and the community understand that the state uses the criminal law to condemn publicly the offender, who experiences shame because of the notoriety of his punishment. Punishment is an overdetermined concept, for while the idea of punishment qua punishment and punishment for deterrence are conceptually distinct, it is difficult to unravel the two when imposing a sanction. Although policymakers and courts may seek primarily to achieve one of the alternative ends of the criminal sanction, the core retributive aspect of the criminal sanction remains. The principal paradigmatic purpose of the criminal law-the reason for invoking criminal law rather than some alternative sanctioning system-is punishment. Basic texts on criminal law and case law readily illustrate this point.

The principal paradigmatic purpose of the civil sanction, on the other hand, is compensation for damage caused. ${ }^{46}$ This is borne out in conventional views of the law of torts. As Prosser put it:

There remains a body of law whch [sic] is directed toward the compensation of individuals, rather than the public, for losses which they have suffered within the scope of their legally recognized interests generally, rather than one interest only, where the law considers that compensation is required. This is the law of torts. ${ }^{47}$

Tort law made compensation for actual damages the essence of its function. "[A] civil satisfaction in damages," said Blackstone, constitutes compensation for a "private wronge"; whereas "a public mischief" is punished "to secure to the public the benefit of society, by preventing or punishing every breach and violation of those laws" and operates through "the terror of punishment or the

176, 179 (1952) (suggesting purpose of punishment is deterrence); Johannes Andenaes, The General Preventive Effects of Punishment, 114 U. PA. L. REV. 949 (1966) (same); Morris R. Cohen, Moral Aspects of the Criminal Law, 49 YALE L.J. 987, 1012 (1940) (suggesting rehabilitation is "most popular theory today').

44. See generally KADISH \& SCHULHOFER, supra note 3, at 113-65 (discussing justifications for criminal punishment). The convention of including rehabilitation, deterrence, and incapacitation under the general rubric of punishment confuses effect and purpose. While these types of criminal sentences may not have primarily punitive purposes, they often have primarily punitive effects. $C f$. NIGEL WALKER, WHY PUNISH 1 (1991) (suggesting punishment involves intentional "infliction of something which is . . . unwelcome to the recipient.").

45. See Henry M. HART, JR., The Aims of the Criminal Law, 23 LAW \& CONTEMP. PROBS. 401, 405 (1958) (criminal sanctions "take their character as punishment from the condemnation which precedes them and serves as the warrant for their infliction").

46. See Hall, supra note 28 , at 756 ("Since Plato, at least, compensation was distinguished from punishment just as the respective harms were themselves later differentiated in terms of moral culpability." (citations omitted)).

47. PROSSER, supra note $36, \S 1$, at 5-6 (footnote omitled). 
sword of the public magistrate."48 Courts and commentators have recurrently characterized civil law in this way. ${ }^{49}$

\section{Remedy: Stigma and Incarceration vs. Restitution and Monetary Payments}

The third paradigmatic dimension lies in the remedies provided. A remedy is an action taken by an authoritative body - a legislature, a court, or an administrative agency - to enforce compliance with prescribed conduct or to impose a cost for failure to comply. Every system of legal ordering possesses some kind of remedy. In the past, remedies have included burning at the stake, coerced public service, payment of money, and imprisonment. ${ }^{50}$ However subdivided, all remedies are used to achieve the purpose of the sanctioning law, whether it be civil or criminal.

Throughout the history of sanctioning law, commentators have argued that the distinctive remedy of the criminal law is imprisonment or the threat thereof. In modern criminal law, the stigma of a criminal sanction has become a special kind of remedy because of its burdensome and sometimes destructive consequences for the individual. Though other remedies in criminal cases, such as fines and probation, may actually be imposed more often than imprisonment, imprisonment and the special stigma associated with convictions are the core remedies used to achieve the purposes of the criminal sanction.

Two paradigmatic remedies exist in civil law, each closely linked to the purpose of the civil law. The first is the court order mandating a return to the status quo ante, so as to make the injured party whole, or enjoining the continuation of injury. The second is the order to pay money as compensation for damage caused. Blackstone succinctly described the remedies of the civil law:

Now, as all wrong may be considered as merely a privation of right [in the civil law], the one natural remedy for every species of wrong is the being put in possession of that right, whereof the party injured is deprived. This may either be effected by a specific delivery or restoration of the subject-matter in dispute to the legal owner; ... or, where that is not a possible, or at least not an adequate remedy, by making the sufferer a pecuniary satisfaction in damages . . . 51

48. See 4 BLACKSTONE, supra note 40 , at *6-7.

49. Prosser called punitive damages in tort an "anomalous" situation indicating that "the ideas underlying the criminal law have invaded the field of torts." PROSSER, supra note 36 , $\$ 2$, at 9; see also Priest, supra note 37, at 470 (noting that influential tort scholar Fleming James "conceived the principal function of tort law to be . . compensation of the injured"); cf. George P. Fletcher, Fairness and Utility in Tort Theory, 85 HARV. L. REV. 537, 543-64 (1972) (suggesting that real confrontation in history of tort is between paradigm of reciprocity and paradigm of reasonableness).

50. In contemporary legal systems, remedies vary widely, including payment of money, disqualification, forfeiture of property, imprisonment, declaration of standards, administrative regulations, orders to comply with standards (injunctions), deprivation of services and financial support, deprivations of rights to conduct transactions, incarceration in nonprison institutions, other restrictions on movement, and stigmatization.

51. 3 BLACKSTONE, supra note 40 , at $* 116$. 
Within the paradigmatic framework, the civil law was meant to provide remedies specifically designed to repair the damage or provide money to enable the victim to obtain the value of the damage caused. ${ }^{52}$

\section{Procedure: High vs. Low Certainty and State vs. Private Initiative}

Procedure regulates the application of a sanctioning system's remedies. ${ }^{53}$ Thus, the capacity of any system of law to mete out sanctions against wrongdoers depends in part on its procedural characteristics. Two elements of procedure are central for distinguishing paradigmatic criminal and civil law: evidentiary rules and the identity of the moving party.

\section{Evidentiary Rules}

The presentation of information about conduct to a decisionmaker is a sine qua non of sanctioning. ${ }^{54}$ Three fundamental questions about information necessary to the sanctioning process capture the paradigmatic differences in evidentiary rules between civil and common law.

First, what methods may be used to obtain access to information? This question focuses on the rules defining investigatory powers, such as when and where a search may be conducted, and whether an authoritative entity may force witnesses to produce documents or to testify. Paradigmatic criminal procedure allows more intrusion into individual and corporate domains and more compulsion over targets of investigation than does paradigmatic civil procedure. ${ }^{55}$ Within the framework of the paradigms, the state has more leverage over targets in the criminal process than does a plaintiff over a defen-

52. The primary sanctions within each paradigm do not describe the full range of remedies available in either of the two categories. Imprisonment and stigma, though characteristically associated with the criminal law, also occur in civil cases. Imprisonment compels obedience to court orders, and stigma attaches to civil findings of fraud and to severe civil penalties, such as censure, delicensing, and disqualification. Nevertheless, the clustering of imprisonment and stigma in criminal cases and of restitution and compensation in civil cases drives the paradigmatic assumptions about remedies in civil and criminal law.

53. PACKER, supra note 18, at 149-73 (procedure expresses societal values by determining certainty required in decisionmaking processes and role of other values, such as privacy and autonomy).

54. For an analysis of the importance of rules about information access and disclosure in procedure, see Wayne D. Brazil, The Adversary Character of Civil Discovery: A Critique and Proposals for Change, 31 VAND. L. REV. 1295, 1315-20 (1978); Mirjan Damaßka, Evidentiary Barriers to Conviction and Two Models of Criminal Procedure: A Comparative Study, 121 U. PA. L. REV. 506 (1973); see also KENNETH MANN, DEFENDING WHITE-COLLAR CRIME: A PORTRATT OF ATTORNEYS AT WORK (1985) (discussing pretrial litigation process in criminal cases); GLEN O. ROBINSON ET AL., THE ADMINISTRATTVE PROCESS 505 (3d ed. 1986) ("Any administrative action, whether formal or informal, is conditioned by the information the agency obtains from its prior investigation."). More extensive literature exists on information access and control in related fields, the lessons of which have not been sufficiently applied to law. See, e.g., M.A.P. WILLMER, CRIME AND INFORMATION THEORY (1970); Andrew M. Pettigrew, Information Control as a Power Resource, 6 Sociology 187 (1972); Richard W. Wilsnack, Information Control: A Conceptual Framework for Sociological Analysis, 8 URB. LIFE 467 (1980).

55. For example, FED. R. CRIM. P. 41(b) provides that "[a] warrant may be issued under this rule to search for and seize any ... property that constitutes evidence of the commission of a criminal offense." 
dant in the civil process. This additional leverage is best exemplified in the police powers of search and custodial interrogation, and the prosecutor's power to subpoena witnesses before a grand jury. ${ }^{56}$

Second, what sources of information are admissible in the decisionmaking process? One system of sanctions may, for instance, base its decisions on information provided by the potential subject of the sanction. A different system may prohibit the use of information provided by the subject of the sanction, requiring exclusive reliance on witnesses. Within the paradigms, criminal procedure historically put more limitations on the information available in the decisionmaking process than did civil procedure. The rules of evidence exemplify these differences. The privilege against self-incrimination and the prohibition on character evidence, for instance, are broader in the criminal process than in the civil process.

Third, what level of certainty is required for the imposition of sanctions? Variation in factual certainty is a central concern when comparing sanctioning systems. One system of sanctions may impose remedies on the basis of facts creating a suspicion in the mind of a single person, while another system may require that many members of a judicial body reach unanimous agreement that all exculpatory explanations of any probability are false. Paradigmatic criminal procedure requires more information than paradigmatic civil procedure because it puts a higher value on certainty before imposing sanctions. This is because criminal penalties are thought to be more severe than civil penalties. ${ }^{57}$ Paradigmatic criminal procedure requires proof beyond a reasonable doubt; paradigmatic civil procedure requires only a preponderance of evidence. ${ }^{58}$ Thus, a plaintiff could win a civil case while the government could lose a criminal case against the same defendant based on the same evidence.

Civil and criminal law answer the foregoing evidentiary questions differently because of the different public interests implicated by wrongful conduct and because of the fear of the intrusive and punitive use of state power. A fundamental principle of due process requires a positive correlation between investigative intrusiveness and severity of sanction on the one hand and stringency of procedural protections on the other. The rules of information control defined here-that is, the rules of evidence-reflect these values. They require special procedural protections for the investigative techniques of the criminal process,

56. In civil cases, more discovery is available to the plaintiff after the case has been filed than exists for the prosecutor at the parallel stage. Under FED. R. CIV. P. 34(a), "[a]ny party may serve on any other party a request ... to produce and permit the party making the request ... to inspect and copy, any designated documents." But this power does not begin to compare with the power of compulsion under grand jury subpoena or the intrusion incident to a physical search for documents.

57. Thus as long as civil monetary sanctions were considered nonpunitive, no reason existed to require special procedural protections. A major achievement of middleground jurisprudence is the recognition of the punitive nature of more-than-compensatory monetary sanctions, and the consequent development of special procedural rules. See infra Part II.C.

58. 9 JOHN H. WIGMORE, EVIDENCE IN TRIALS AT COMMON LAW $\S \S 2497,2498$ (James H. Chadboum rev. ed. 1981). 
restrict the admissibility of evidence in criminal cases, and require greater certainty before allowing the imposition of criminal sanctions. Thus, the different procedural rules in the paradigmatic forms of criminal and civil law reflect distinct attitudes toward the severity of sanctions and due process. ${ }^{59}$

\section{The Moving Party}

Following the English example, by the twentieth century, the paradigms of civil and criminal law in the United States indicated that the state held the role of moving party in the criminal law, whereas a private party was the moving party in civil law. ${ }^{60}$ The paradigms reflect the idea that the state should hold the power to sanction offenders when the purpose of the sanction is punishment. Complementing this idea, private parties control the sanction in paradigmatic civil law, in which the purpose of the sanction is compensation. In this arrangement, the violation of private interest calls for mobilizing action on the part of the private party. ${ }^{61}$

\section{E. A Summary of Principal Paradigmatic Distinctions}

The arrangement of the generic dimensions of sanctioning systems defines the normative framework in which much of the jurisprudence of sanctions has developed. The table below summarizes the distinctive key dimensions of civil and criminal law. ${ }^{62}$

59. These neatly bifurcated principles of information control do not reflect the real variability of procedure in what is labeled criminal and civil law. Stark differences between civil and criminal procedure have eroded markedly. Indeed, the following analysis shows that the growth of punitive sanctions in civil procedural settings, which has radically altered the conventional paradigmatic balance, is partially explained by the desire to reduce evidentiary barriers to sanctioning without relinquishing punitive purposes.

60. See Douglas Hay \& Francis Snyder, Using the Criminal Law, 1750-1850: Policing, Private Prosecution, and the State, in POLICING AND PROSECUTION IN BRTAAN 1750-1850, at 3, 24 (Douglas Hay \& Francis Snyder eds., 1989) ("Private prosecution was not itself a term commonly used in the eighteenth century: when a distinction was necessary, it was to note the exception, 'a prosecution at the expense of the crown."'). According to Blackstone, "[I]ndictments . . . are preferred . . . in the name of the King, but at the suit of any private prosecutor ...." Id. In the United States, "the elimination of the private prosecutor was achieved early. ... [B]y the time of the Revolution the change was virtually complete for serious offences." Id. at 30.

61. Two significant developments in the American law of sanctions have weakened the validity of the paradigmatic bifurcation between the state and a private party. One is the creation of "private attorneys general," as in the RICO statute, which allows private parties to "prosecute" civilly criminal wrongs and to move for severely punitive sanctions. The other is the development of mechanisms that allow the state to move in a civil suit for the compensation of private parties, for example, by disgorging trusts established by the SEC in civil cases against persons or entities who have fraudulently operated in the securities markets. Yet in spite of these critical changes in the conventional role of the moving parties, the paradigms of criminal and civil law continue to dominate the jurisprudence of sanctions.

62. In contrast to this Article, one commentator attributes the civil-criminal distinction to only one criterion, the presence or absence of a punitive purpose. This approach tends to eliminate any role for punitive civil sanctions. See Note, Civil RICO is a Misnomer: The Need for Criminal Procedural Protections in Actions Under 18 U.S.C. \$ 1964, 100 HARV. L. REV. 1288, 1290-92 (1987) (arguing that "criminal/civil distinction stems from the punitive nature of criminal statutes"); see also Cheh, supra note 14, at 1336 (essence of criminal case is formal designation of moral guilt by communal judgment with attendant 
TABLE 1. Summary of the Criminal and Civil Paradigms

\begin{tabular}{lll}
\hline & \multicolumn{1}{c}{$\begin{array}{c}\text { CRRMNAL } \\
\text { PARADIGM }\end{array}$} & \multicolumn{1}{c}{$\begin{array}{c}\text { CIVIL } \\
\text { PARADIGM }\end{array}$} \\
\hline MOVINO PARTY & State & Private Entity \\
WrONG DEFINED & $\begin{array}{l}\text { Subjective Liability: } \\
\text { Violation of Public Norms }\end{array}$ & $\begin{array}{l}\text { Objective Liability; } \\
\text { Actual Injury to } \\
\text { Private Interests }\end{array}$ \\
PROCEDURB & $\begin{array}{l}\text { 1) High Leverage to Obtain } \\
\text { Information }\end{array}$ & $\begin{array}{l}\text { 1) Low Leverage to Obtain } \\
\text { Information }\end{array}$ \\
& $\begin{array}{l}\text { 2) Restrictive Admissibility } \\
\text { of Evidence }\end{array}$ & $\begin{array}{l}\text { 2) Inciusive Admissibility } \\
\text { of Evidence }\end{array}$ \\
3) High Burden of Proof & 3) Low Burden of Proof \\
REMEDY & Imprisonment; Stigma & Money Payment; Injunction \\
PURPOSE & Punishment & Restitution; Compensation
\end{tabular}

The paradigms have shaped our overall understanding of legal sanctions and have often constituted normative measuring sticks for certifying or disapproving new forms of legal sanctions. They continue to inform the legal mind today. However, the paradigmatic criminal process and the paradigmatic civil process accurately describe only part of the empirical arena of sanctioning processes. They fail to capture the special combination of punitive purposes and civil procedural rules that characterizes hybrid sanctions, which occupy a vast middleground between criminal and civil law. The middleground is not sui generis in the sense that it possesses distinctive characteristics found in neither of the paradigms; rather, it mixes the characteristics of these paradigms in new ways. Against the background of strongly perceived conventional paradigms, the middleground represents a truly hybrid sanction.

\section{MidDLEGROUND JURISPRUDENCE}

The third arena of sanctioning law, punitive civil sanctions, developed simultaneously with the criminal and civil paradigms. This part shows that the legitimacy of punitive civil sanctions has been challenged repeatedly, precisely because they do not fit in either paradigm. In response, the courts have fashioned a complicated but unequivocally supportive jurisprudence to justify the place of punitive civil sanctions in the constitutional structure of American law. Using fictional approaches to deny that these punitive civil sanctions constitute punishment, the courts have avoided burdening such sanctions with the procedural barriers of the criminal law. 


\section{A. The Field of Inquiry}

Within the field of punitive civil sanctions, state-invoked and privately invoked sanctions must be distinguished. Until very recently, state-invoked and privately invoked punitive civil sanctions developed autonomously, for the most part, through two different lines of cases. Occasionally, however, the two converged. Courts have relied, for example, on the theory of exemplary damages in tort to explain punitive civil sanctions in state-invoked cases. This tendency has become more evident in recent case law and may foreshadow the consolidation of state and private civil punitive sanctions. This would cause procedures to develop along one rather than two strands. ${ }^{63}$ Although my analysis focuses on state-invoked civil punitive sanctions, I will refer to privately invoked punitive civil sanctions where they have been integrated into the jurisprudence of state-invoked civil sanctions.

In emphasizing state-invoked punitive civil sanctions, I examine their definitions and justifications in the courts and the role they have come to play in the larger field of sanctioning law. As part of my thesis, I assert that the difference between state-invoked and privately invoked civil sanctions has been overstated and deserves less attention than it receives in present doctrine. I argue that, given the strong parallel between private and public punitive sanctions, the procedural qualities of privately invoked punitive civil sanctions should be shaped in close relation to the principles appropriate for state-invoked punitive civil sanctions.

\section{More-than-Compensatory Monetary Sanctions}

In assessing the case law regarding state-invoked punitive civil sanctions, I consider only those monetary sanctions, such as multiple damages, civil money penalties, and forfeitures, that do not merely mirror the damage caused. ${ }^{64}$ Multiple damages require a monetary payment measured by a multi-

63. Although courts imposed privately invoked punitive civil sanctions in 19th-and early 20th-century American law, they were uncertain about the propriety of state-invoked punitive civil sanctions. The distrust of state authority in the new American community, expressed in the Bill of Rights, created ambivalence in the judiciary toward state use of punitive power. In some challenges to the legitimacy of state-invoked punitive sanctions, courts drew on the concept of punitive damages in private law to sustain them in public law. See infra notes 116-17, 169 and accompanying text.

64. Punitive civil sanctions are not always monetary. Nonmonetary punitive sanctions raise problems similar to those raised by monetary sanctions. However, the role of punishment in nonmonetary punitive sanctions is less focused because they are used more often for prophylactic or remedial purposes. Disbarment of a lawyer for embezzling client funds or disqualification of a military hardware supplier for overcharging, for example, are nonmonetary sanctions that may be justified as a way of protecting the public from future wrongful conduct. Nonmonetary sanctions might also be intended as both punitive and remedial. Focusing on monetary sanctions alone highlights the issue of punishment more clearly. For one example of the contemporary growth of nonmonetary sanctions, see Jayne W. Barnard, The Securities Law Enforcement Remedies Act of 1989: Disenfranchising Shareholders in Order to Protect Them, 65 NOTRE DAME L. REV. 
ple of actual damage, usually double or treble, in addition to disgorgement, restitution, and simple compensation. Civil money "penalties" resemble multiple damages, but carry a stigma for the losing defendant that is not usually associated with the label "multiple damages." Money penalties are often determined independently of the damage caused, which makes them potentially more disproportionate to actual damage than multiple damages. Furthermore, they are sometimes assessed through administrative rather than judicial proceedings. Forfeitures, which impose a monetary payment equivalent to the value of the property forfeited, are also unrelated to the amount of damage caused. They too impose a noncompensatory payment on the property owner ${ }^{65} \mathrm{~A}$ distinctive aspect of the forfeiture proceedings is that the action is brought against the property (in rem) rather than against the person. ${ }^{66}$

The following description of middleground jurisprudence will substitute the phrase "more-than-compensatory monetary sanctions" or simply "money sanctions" for "punitive civil sanctions." The use of this neutral expression avoids predetermining the central questions the courts have faced assessing these sanctions, namely whether and to what extent they are punitive. The answers carry important consequences for the applicable procedural rules.

\section{The Problem}

An analysis of over a century of cases involving more-than-compensatory monetary sanctions reveals a recurring basic structure. First, the government initiates a proceeding against a defendant, using a sanctioning process labeled as civil and controlled by civil procedural rules. After an adverse judgment, the defendant then challenges a particular aspect of the proceeding on appeal-for instance, the evidentiary standard applied to impose sanctions - by arguing that the case, though labeled civil, was actually a criminal action. In pursuing this line of argument, the defendant refers to the conventional criminal and civil paradigms as defining the traits of a criminal or civil case. Finally, the government either denies the validity of the paradigms or argues for a deviation from them, implicitly calling for the affirmance of the hybrid sanctioning form.

32 (1989) (discussing SEC's desire to expand power to bar corporate officers from future executive positions in public corporations due to past misconduct as corporate officials).

65. A distinction must be drawn between forfeitures of contraband and forfeitures of noncontraband property or money. The term money sanction, as used in this Article, includes only the latter. To illustrate this distinction, when a defendant in a drug enforcement action forfeits the drugs and the home in which the drugs were stored, only the latter is a forfeiture of noncontraband property although both may cause substantial monetary loss to the sanctioned subject.

66. See Calero-Toledo v. Pearson Yacht Leasing Co., 416 U.S. 663, 680-86 (1974); see also Alice M. O'Brien, Note, "Caught in the Crossfire": Protecting the Innocent Owner of Real Property from Civil Forfeiture Under 21 U.S.C. $\$ 881(a)(7), 65$ ST. JOHN's L. REV. 521, 526 (1991) ("Congress sought to supplement the more traditional criminal penalties by providing a law enforcement device that would not only punish, but would also strip offenders of their economic gains." (footnote omitted)). 
The modal problem raises two fundamental issues: Is the government allowed to proceed with the sanction in a civil procedural setting? If so, are special procedural protections necessary because the sanction was more than compensatory? The first question touches on the very nature of more-than-compensatory monetary sanctions. If a court considered these to be criminal sanctions, the government would be forced to resort to the criminal process whenever these sanctions were used. Consequently, the middleground would be eliminated. The second question addresses the nature of the procedure. If the civil procedural setting is acceptable, what particular rules of civil procedure will have to be used to protect defendants from governmental overintrusiveness and from erroneous imposition of the sanction?

\section{B. Jurisprudential Approaches}

The United States Supreme Court has taken four principal approaches to the modal problem: punitive, formal procedural, compensatory, and deterrence. Each approach exists simultaneously with the others, none having chronological priority. I explicitly criticize three of these approaches. First, I argue that the jurisprudence of sanctions should always have a functional orientation; yet only the punitive approach adopts a true functional analysis. Second, a sanction's function should always correlate with the procedure for its imposition; as function varies, so should procedure. Again, only the punitive approach meets this criterion. Each of the other approaches either uses legal fictions to conceal the real nature of the sanctions or rejects the connection between function and procedure. The punitive approach, as I have labeled it, is the only one of the approaches to more-than-compensatory monetary sanctions that clearly identifies function and connects it directly to the procedural characteristics of the sanction.

\section{The Punitive Approach}

The punitive approach's identification of a punitive or quasi-criminal purpose in more-than-compensatory monetary sanctions distinguishes it from other approaches. Even when it finds that a money sanction was meant to punish, the Court does not strike down the sanction as a violation of substantive or procedural due process (because it fits neither the criminal nor the civil paradigm). But the recognition of a punitive purpose has important procedural consequences: special criminal-type procedural rules not found within the conventional civil paradigm apply, providing enhanced protections for the defendant.

The Supreme Court recognized the validity of punitive purposes in civil cases early on, but made the imposition of punitive sanctions contingent on 
heightened procedural protections. ${ }^{67}$ In a number of these cases, the Court rejected the idea that the procedural form determined by Congress-civil procedure-was a definitive indicator of the sanction's purpose. ${ }^{68}$

United States v. Chouteau ${ }^{69}$ involved a civil suit brought under a statute prohibiting the distillation of liquor without payment of taxes and making violators "liable to a penalty of double the tax imposed" in addition to possible fines and imprisonment. ${ }^{70}$ In deciding whether a criminal prosecution and settlement barred a subsequent civil suit for the statutory penalty under the Double Jeopardy Clause, the Court said:

Admitting that the penalty may be recovered in a civil action, as well as by a criminal prosecution, it is still . . . a punishment for the infraction of the law. The term "penalty" involves the idea of punishment, and its character is not changed by the mode in which it is inflicted, whether by a civil action or a criminal prosecution. ${ }^{71}$

In Chouteau the Court reasoned that a sanction with a punitive purpose must comply with at least some of the rules designed for paradigmatically punitive cases. While the Constitution provides protection against double jeopardy, it does not define civil and criminal cases. Only the preexisting jurisprudence could provide those definitions. The Chouteau Court found in it the prevalent ideas that penalty means punishment and that punishment, as a criminal sanction, must raise the double jeopardy bar. Chouteau reflected and reinforced the strength of the paradigms in the jurisprudence of sanctions; a line of subsequent cases cited it for the proposition that '[t]he term 'penalty' involves the idea of punishment for the infraction of the law."

67. See, e.g., Coffey v. United States, 116 U.S. 436 (1886) (holding that acquittal on criminal charges of defrauding government of taxes on distilled spirits barred subsequent civil forfeiture suit because civil forfeiture has punitive purposes). The Supreme Court overruled Coffey in United States v. One Assortment of 89 Firearms, 465 U.S. 354, 361 (1984). See infra note 105.

68. In several early cases the Court took a functional view of monetary sanctions. See United States v. Constantine, 296 U.S. 287 (1935) (holding that excise tax grossly disproportionate to normal tax for retail liquor dealers who violate state law constitutes penalty); Lipke v. Lederer, 259 U.S. 557, 562 (1922) (holding that "tax" that "clearly involves the idea of punishment for infraction of the law" is penalty); Helwig v. United States, 188 U.S. 605 (1903) (holding additional duty imposed for undervalued customs declaration that is greatly in excess of regular duty penal in character).

69. 102 U.S. 603 (1880).

70. Id. at 605 .

71. Id. at 611. The text of the statute at issue in Chouteau reveals a close connection between the monetary sanction and a prison term, indicating that Congress may have viewed the sanction as part of a punitive sentence. Textual connection was used as an indicator of sanction type in penalty as well as in forfeiture cases. See, e.g., In re Leszynsky, 15 F. Cas. 397 (C.C.S.D.N.Y. 1879) (No. 8279). In that case, the court reasoned that "[w] here the same section of [a] statute contains the description of the offence, and the prescription of the penalty by civil suit, and of the punishment on a criminal conviction, the two connected by the copulative 'and,' no other construction is proper than that the whole is one punishment, and that the whole cannot be satisfied by a part." Id. at 399.

72. O'Sullivan v. Felix, 233 U.S. 318, 324 (1914); see also Huntington v. Attrill, 146 U.S. 657, 667 (1892) ("[s]trictly and primarily, [the words 'penal' and 'penalty'] denote punishment, whether corporal or pecuniary, imposed and enforced by the State, for a crime or offence against its laws." (citations omitted)). Before Choureau, in United States v. Reisinger, 128 U.S. 398 (1888), the Court stated that "the 
Boyd v. United States, ${ }^{73}$ decided a few years after Chouteau, was pivotal in recognizing a punitive element in money sanctions and requiring heightened procedural protections. The defendant had been found liable under a statute imposing a monetary forfeiture for fraudulent import of merchandise. He appealed on the ground that the trial judge erred in requiring him to produce personal papers in his possession. The appellant argued that, while civil in form, the government's case was actually criminal because of the punitive purpose of the statute under which the prosecution had proceeded. Thus, he claimed the compelled production of documents violated the Fourth Amendment's protection against search and seizure and the Fifth Amendment's privilege against self-incrimination.

Had the Court felt compelled to apply only principles arising from the paradigms, it would have treated the case in all respects as either criminal or civil, but not both. If it were a criminal case, the state would have to refile it in an indictment, prove its case beyond a reasonable doubt, and provide other procedural protections characteristic of the criminal paradigm. According to a criminal analysis, the trial judge erred in not protecting the defendant from compelled disclosure of personal documents. Alternatively, the Court could have held that the forfeiture was exclusively civil and that the defendant had lost any right to the protection claimed. However, the principles of the civil paradigm would limit the value of forfeited property to a measure of actual damages, thus eliminating the remedy's punitive quality.

Not surprisingly, the paradigms did not determine the result. Instead, the Court viewed the forfeiture as a hybrid sanction and called it a "quasi-criminal" remedy to which some criminal-type procedures must apply. Justice Bradley stated for the Court:

As, therefore, suits for penalties and forfeitures incurred by the commission of offences against the law, are of this quasi-criminal nature, we think that they are within the reason of criminal proceedings for all the purposes of the Fourth Amendment of the Constitution, and of that portion of the Fifth Amendment which declares that no person shall be compelled in any criminal case to be a witness against himself

This was a middleground solution because it allowed for the imposition of a more-than-compensatory sanction in a civil proceeding. Further, it illustrated the functional approach to the middleground. In considering the claim for the application of procedural rules traditionally rooted in the criminal paradigm, the Court stated that heightened procedural protections would apply if the

words 'penalty,' 'liability,' and 'forfeiture' ... have been used by the great masters of crown law and the elementary writers as synonymous with the word "punishment." Id. at 402.

73. 116 U.S. 616 (1886).

74. Id. at 634 . 
sanction had a punitive purpose. This middleground approach applied despite the congressionally chosen label of the sanction and the designated procedural mechanism, both of which were civil. In calling the sanction quasi-criminal, the Court self-consciously mixed elements of existing bipolar paradigms, creating a true middleground jurisprudence without explicitly identifying it as such. $^{75}$

Chouteau and Boyd emerged at the turn of the century as key cases in defining punitive sanctions, as well as in establishing procedural requirements for the imposition of punitive sanctions in civil settings. They consolidated earlier themes of a functional jurisprudence and generated subsequent decisions that assessed a sanction's real purpose rather than considering themselves bound by an action's label. ${ }^{76}$

Holdings that the forfeiture and money penalty were intended to punish-based on an analysis of the purposes of the relevant statutory clauses-led to the formation of a definitive middleground approach affirming the idea that state-imposed punishment was a legitimate end of the civil process. This entailed a significant deviation from the basic bifurcation between the two paradigms, which inexorably linked punishment to the criminal process. ${ }^{77}$

The punitive approach has continued to constitute part of the middleground jurisprudence, first in applying certain aspects of the Fourth Amendment protection of privacy to punitive proceedings, ${ }^{78}$ and later in applying the privilege against self-incrimination to certain punitive proceedings. ${ }^{79}$ This

75. The Court was drawn to this middleground solution because forfeiture contained both civil and criminal elements. First, forfeiture has traditionally been essentially an in rem action, a suit against property, not against a person, and so the legal proceeding to compel forfeiture has traditionally been civil in form. See United States v. One Assortment of 89 Firearms, 465 U.S. 354, 363 (1984). This has been a compelling argument for maintaining the civil character of any forfeiture, including forfeiture of money as a punitive sanction for wrongful conduct.

Second, the forfeiture clause in Boyd was contingent on the commission of a crime; it called for a fine or imprisonment of the offender and the forfeiture of the merchandise. Boyd, 116 U.S. at 617. This was a persuasive reason for viewing the particular forfeiture as a criminal sanction.

76. See, e.g., Lees v. United States, 150 U.S. 476 (1893). In Lees, the Court examined a statute under which the United States sought to recover "the sum of one thousand dollars, as a forfeit and penalty" from any person violating an act that prohibited importation of foreigners and aliens to perform labor in the United States. Id. at 477-78. The Court interpreted the statute as criminal but did not consider the penalty proceedings to be criminal prosecutions. "[A]lthough the recovery of a penalty is a proceeding criminal in its nature, yet in this class of cases it may be enforced in a civil action, and in the same manner that debts are recovered in the ordinary civil courts." Id. at 479 . But as in Boyd, the Court found incongruous the joining of punitive purpose with a civil procedural principle denying protection from self-incrimination. Lees held that the self-incrimination rule applied in a civil case that imposes criminal penalties: "This, though an action civil in form, is unquestionably criminal in its nature, and in such a case a defendant cannot be compelled to be a witness against himself." Id.

77. The Supreme Court might have adopted another approach to the mixed sanction: the invalidation of a civil suit for punitive purposes as violative of due process. Such a holding would have obstructed the use of more-than-compensatory money sanctions in civil settings.

78. See One 1958 Plymouth Sedan v. Pennsylvania, 380 U.S. 693 (1965) (holding that exclusionary rule applies to forfeiture proceedings that are punitive in nature).

79. See United States v. United States Coin \& Currency, 401 U.S. 715 (1971) (holding that protection from self-incrimination applied to tax proceeding because function of forfeiture was to penalize only persons involved in criminal enterprises). 
approach can trigger the application of special protective procedural rules designed to facilitate accuracy in decisionmaking as well as to safeguard the privacy interests of citizens. But the role of the punitive approach has become minor in middleground jurisprudence because the Court has increasingly used other strands of middleground jurisprudence that reject the punitive nature of the money sanction. In the other strands, the Court has rendered superfluous the question of whether criminal-type procedural rules need to apply.

\section{Formal Procedural Approach}

If a court employing the formal procedural approach to more-than-compensatory money sanctions finds that the procedural mechanism for collecting the money was historically civil, then it will treat the sanction itself as civil. In this approach, form dominates substance; the legislature's choice of civil procedure confers an exclusively civil status on the sanction. Consequently, special procedural protections are not imposed.

The formal procedural approach builds mainly on Stockwell v. United States. ${ }^{80}$ As in Boyd, the defendant claimed that the government erred by proceeding in the civil arena, arguing that the sanction was punitive and therefore criminal in character. In this case, however, the Court rejected the defendant's claim that payment of double the value of the illegally imported goods constituted a criminal or quasi-criminal action.

Writing for the Court, Justice Strong relied on the procedural character of the statutory mechanism for imposing the penalty, without assessing the statute's purpose: "[W] hether the liability incurred is to be regarded as a penalty, or as liquidated damages for an injury done to the United States, it is a debt,

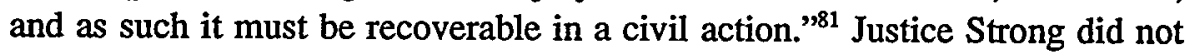
find the more-than-compensatory measure of payment problematic, or consider the statute's use of the term "on conviction thereof" a prerequisite for the double damage payment. In emphasizing the importance of the procedure defined by Congress for collection of the money, the Justice stressed that "[ $[$ ] expression 'sued for and recovered' is primarily applicable to civil actions, and not to those of a criminal nature. ${ }^{182}$ The Court took a quintessentially positivist view of sanctions: if a sanction is labeled civil, it is civil.

This formal procedural approach stems from English law, in which scholars and jurists used the term "penalty" to describe a category of sanctions for breaches of public wrongs that were neither criminal nor entirely civil in character. Blackstone, exemplifying this view, discussed penalty cases in his volume on private wrongs. ${ }^{83}$ In English law, the civil penalty arose from the

80. 80 U.S. (13 Wall.) 531 (1871).

81. Id. at 542 .

82. Id. at 543.

83. 3 BLACKSTONE, supra note 40. 
concept of an implied contract between every citizen and the civic polity or the King. ${ }^{84} \mathrm{~A}$ breach of the contract entitled the King, or a private party acting in the name of the King, to liquidated damages. Blackstone put it thus: "The party offending is here bound by the fundamental contract of society to obey the directions of the legislature, and pay the forfeiture incurred to such persons as the law requires." ${ }^{\prime 85}$ In the law of implied contract, the civil penalty was thus a debt to be paid for satisfaction of damages, which could be collected in a civil suit like any other debt. In identifying the paradigm that properly described the sanction, the means of collection was more important than the sanction's function.

For Blackstone, it was evident that acts of Parliament could require payments or forfeitures and penalties for wrongdoing without those payments being called criminal punishments. As implied social contracts between citizens and the King, in which damages were assessed $a$ priori rather than being tied to a post hoc measure of injury actually caused, they were grounded more in contract than in criminal law. However, these payments left ambiguous the questions of the appropriate classification and of the applicable procedure.

Atcheson v. Everitt ${ }^{86}$ illustrates the ambiguity of the English law of sanctions. In Atcheson, a defendant in a civil penal action claimed that the proceeding was criminal, and that therefore evidence given by a Quaker should be excluded because Quakers would not give testimony under oath, as required by the criminal law. ${ }^{87}$ Lord Mansfield responded with a definitively "civil" view of penal actions:

Mr. Justice Blackstone, and all modern and ancient writers upon the subject distinguish between them. Penal actions were never yet put under the head of criminal law, or crimes. The construction of the statute must be extended by equity to make this a criminal cause. It is as much a civil action, as an action for money had and received. The legislature, when they excepted to the evidence of Quakers in criminal causes, must be understood to mean causes technically criminal; and a different construction would not only be injurious to Quakers, but prejudicial to the rest of the King's subjects who may want their testimony. ${ }^{88}$

84.

For it is part of the original contract, entered into by all mankind who partake the benefits of society, to submit in all points to the municipal constitutions and local ordinances of that state, of which each individual is a member. Whatever therefore the laws order any one to pay, that becomes instantly a debt, which he hath beforehand contracted to discharge.

Id. at *158.

85. Id. at *159.

86. 98 Eng. Rep. 1142 (K.B. 1775).

87. Id. at 1147 .

88. Id. (emphasis omitted). In spite of their inclusion in the civil category, penalty suits had a more ambiguous status than appears in Lord Mansfield's opinion. For instance, counsel for the defense recognized that the criminal nature of the sanction could be important: 
The question raised in Atcheson foreshadowed the one facing American courts in the nineteenth and twentieth centuries: should a procedural rule developed for criminal cases-creating a special protection for defendants in criminal cases because of the seriousness of the sanction's consequences-apply in a case technically labeled "civil," but whose purpose appears to be punitive?

Notwithstanding Lord Mansfield's rejection of the criminal label and its corresponding procedural protections, the status of the penalty suit remained unsettled. Indeed, the issue in Atcheson prefigured a long period of litigation in the U.S. Supreme Court about the nature of state-invoked money sanctions. The decision in Stockwell, which adopted the formal procedural approach, constituted a major anchoring point for subsequent cases dealing with morethan-compensatory money sanctions. ${ }^{89}$

Why were Stockwell, the leading case defining the formal procedural rationale, and $B o y d d^{90}$ the leading case defining the punitive approach, decided differently, even though each case involved a money judgment well beyond simple compensation? One distinction is that in Boyd the statutory provision authorizing money sanctions also authorized purely criminal sanctions, making the money sanction look like one of a number of possible criminal sentences. In Stockwell, by contrast, the provision authorizing double damages was separate and distinct from a later act of Congress that imposed a fine and a prison term. The Court felt that the separate statutes indicated that Congress intended the different sanctions to coexist, for the later law did not repeal the earlier one. Boyd and Stockwell suggest that civil and criminal penalties could both be imposed on the same defendant for the same conduct, so long as the legislature had expressed its intention to create both sorts of sanctions. Under

Punishment is a legal term, and is understood to be in consequence of some offense. The charge against the defendant is a charge of bribery. The statute upon which the action is brought, treats bribery as an offense, throughout, and the person committing it as an offender. Consequentiy it considers bribery as a crime... . [B]ribery was a crime at common law: and the penalty given by the statute is only part of the fine due at common law to the public in satisfaction of the offense: besides which, the statute inflicts additional pains and penalties which are also incurred by the judgment. Id. at 1143.

89. Hepner v. United States, 213 U.S. 103 (1909), further developed the Stockwell rationale. Hepner appealed a civil "penalty" of $\$ 1,000$ for illegal importation of aliens, arguing that the sanction was in fact a criminal punishment and that a directed verdict was therefore inappropriate. Rejecting this claim, Justice Harlan wrote that "[i]t must be taken as settled law that a certain sum, or a sum which can readily be reduced to a certainty, prescribed in a statute as a penalty for the violation of law, may be recovered by civil action, even if it may also be recovered in a proceeding which is technically criminal." Id. at 108. Hepner extended the consequence of Stockwell by permitting a judge to take a penalty case away from a jury based on her independent assessment of the evidence.

If the outcome in Hepner derived from the view that the privilege against self-incrimination, considered in Boyd v. United States, 116 U.S. 616 (1886), was more important than, or at least different in some sense from, the privilege against directed verdicts, then Hepner narrowed Boyd's potential meaning, cutting off a possible amplification and refinement of the punitive approach. See also United States v. Zucker, 161 U.S. 475, 481 (1896) (Sixth Amendment right to confrontation applies only to prosecutions specifically labeled "criminal," not forfeitures sought in civil suits).

90. 116 U.S. 616. For discussion of Boyd, see supra notes 73-75 and accompanying text. 
the formal procedural approach, the legislature could express this intention by simply choosing civil forms for some of its sanctions; that very choice defined the sanctions as civil. The Court did not address the tautological nature of this reasoning. Indeed, much of the formalist jurisprudence falsely implied that the legislators who enacted more-than-compensatory money sanctions harbored no punitive intentions, that the authorities who administered such sanctions used them to serve no punitive ends, and that the people and entities sanctioned did not suffer any punitive effects. Under the Boyd approach, the legal forms stressed by the formal procedural rationale often looked like transparent legal fictions.

\section{Compensatory Approach}

The third approach, which I call the compensatory approach, views money sanctions as "rough compensation" rather than punishment. The money sanction is understood as a means to repay the government for the cost of enforcing the law. The idea that the sanction is technically more than compensatory does not prevent the courts from finding an essentially compensatory arrangement. To explain how the multiple damage sanctions often found in penal statutes can be considered compensatory, the courts have sometimes used the term "liquidated damages," referring to the parallel contract remedy that retains the idea of compensation in a regime of more-than-simple damages. ${ }^{91} \mathrm{~A}$ central implication of the compensatory approach is that no special procedural safeguards are required, for there is no reason to apply a special procedural safeguard for a sanction that is not punitive in purpose.

The compensatory approach came to have a central place in middleground jurisprudence as the legal justification for administrative agencies to possess sanctioning authority. The roots of the compensatory approach lie in Stockwell v. United States, ${ }^{92}$ where Justice Strong used it to supplement his formal procedural rationale. Responding to the defendants' argument that they should not have to pay the monetary sanction because proof of the scienter necessary for criminal punishment was lacking, Justice Strong stated that wrongdoers

91. Contract law distinguishes between liquidated damages and penalties. See RESTATEMENT (SECOND) OF CONTRACTS $\$ 356$ (1981): "Damages for breach by either party may be liquidated in the agreement but only at an amount that is reasonable in the light of the anticipated or actual loss caused by the breach and the difficulties of proof of loss. A term fixing unreasonably large liquidated damages is unenforceable on grounds of public policy as a penalty." Thus, the traditional view does not allow punitive damages for breach of contract. See also Sandra Chutorian, Note, Tort Remedies for Breach of Contract: The Expansion of Tortious Breach of the Implied Covenant of Good Faith and Fair Dealing into the Commercial Realm, 86 COLUM. L. REV. 377 (1986) (criticizing use of tort cause of action to provide adequate damages for bad faith breach, suggesting use of broadened concept of consequential damages in place of punitive damages). But cf. Lake River Corp. v. Carborundum Co., 769 F.2d 1284, 1286-89 (7th Cir. 1985) (identifying "fuzzy line between penalty clauses and liquidated-damages clauses," and stating that "refusal to enforce penalty clauses is (at best) paternalistic-and it seems odd that courts should display parental solicitude for large corporations").

92. 80 U.S. (13 Wall.) 531 (1871). 
should compensate the government for the valuable resources used to investigate illegal importation and in seizing illegal property. This goal made the illegal importation statute in question "remedial" rather than punitive, despite its double damage provision:

It must ... be considered as remedial, as providing indemnity for loss. And it is not the less so because the liability of the wrongdoer is measured by double the value of the goods received, concealed, or purchased, instead of their single value. The act of abstracting goods illegally imported, receiving, concealing, or buying them, interposes difficulties in the way of a government seizure, and impairs, therefore, the value of the government right. It is, then, hardly accurate to say that the only loss the government can sustain from concealing the goods liable to seizure is their single value, or to assert that the liability imposed by the statute of double the value is arbitrary and without reference to indemnification. ${ }^{93}$

The Court used the term "remedial" in its conventional civil sense, as a form of legal proceeding for redressing injury. If successful civil plaintiffs were generally entitled to recover their enforcement costs, including legal fees and the costs of investigating their cases, the idea that the purpose of punitive sanctions was to compensate the government for the costs of enforcement would be more persuasive. Even then, though, Stockwell's failure to make any connection between the actual costs of enforcement and the permissible size of the money judgment seems suspect; rather than trying to estimate enforcement costs in each case, the Court permitted the government's compensation to be set at a multiple of the value of the goods illegally imported.

While there was evidence that Congress intended the sanction to be punitive - the section of the statute dealing with collection procedures, for instance, referred to the double damages as "penalties and forfeitures"94 - the Court found a stronger interpretive guide in analogous private actions for multiple damages:

Double the value may not be more than complete indemnity. There are many cases in which a party injured is allowed to recover in a civil action double or treble damages. Suits for infringement of patents are

93. Id. at 547. In contrast, Justice Field's dissent argued that the monetary sanction at issue constituted a criminal punishment:

Both acts are penal; the first equally so as the last, for it does not go for the value of the goods, or indemnification to the government, but for the enforcement of a penalty upon a party offending in any of the particulars mentioned. The very definition of a penal statute is that it is a statute which inflicts a penalty for the violation of its provisions. It is admitted in the opinion of the majority of the court that the offences designated in the act might be prosecuted by information or indictment, an admission which seems to me to be inconsistent with the position that the act is not penal.

Id. at 554-55 (Field, J., dissenting).

94. Id. at 542 . 
instances, and in some States a plaintiff recovers double damages for cutting timber upon his land. It will hardly be claimed that these are penal actions requiring the application of different rules of evidence from those that prevail in other actions for indemnity. ${ }^{95}$

Though the Court considered it a foregone conclusion that the private multiple damage suit was well grounded in its own jurisprudence, one could argue that, like the state-initiated multiple damage suit, it wrongly introduced punitive purposes into civil actions. Yet even accepting the authority of the case law upholding private multiple damage awards, the Court's equation of private lawsuits with suits brought by the government was facile. Was there not good reason to believe that, regardless of the status of private multiple damage suits, the state should not be permitted to enforce its laws by seeking multiple damages in a civil forum? And even if such civil enforcement suits were legitimate, should not the Court have asked whether such sanctions required special procedural rules? The Court examined neither of these questions, while strengthening the bond between state-initiated and privately initiated punitive civil sanctions.

Stockwell became central to the application of the compensatory approach to sanctions labeled "penalties." defining state authority to levy money penalties the Court drew on Stockwell to decide that money judgments labeled "penalties" required neither the special procedural rules of the criminal paradigm nor a variation on them that could create a procedural middleground. Two of the central arenas of federal law enforcement-tax fraud and false claims on the government-exemplify this approach.

\section{a. Tax Fraud}

Using the compensatory approach as its principal authority, middleground jurisprudence entered a new period with the landmark case of Helvering $v$. Mitchell. ${ }^{77}$ After Mitchell had been acquitted on a criminal charge of tax evasion, the Internal Revenue Service imposed a civil sanction in the amount of fifty percent of his tax deficiency, over and above the deficiency itself. ${ }^{98}$ Mitchell appealed, arguing that double jeopardy principles barred the second

95. Id. at 547.

96. While Boyd v. United States, 116 U.S. 616 (1886), had declared that the word "penalty" indicated a punitive purpose, which carried important procedural implications, Stockwell was interposed in subsequent cases, thereby calling into question Boyd's continued validity.

97. 303 U.S. 391 (1938).

98. Id. at 395 (quoting The Revenue Act of 1928, ch. 852, § 293(b), 45 Stat. 791) ("If any part of any deficiency is due to fraud with intent to evade tax, then 50 per centum of the total amount of the deficiency (in addition to such deficiency) shall be . . . assessed . . .."). 
sanction because its purpose was to punish. ${ }^{99}$ The Second Circuit agreed, holding that Supreme Court precedent required it to view the fifty percent payment as a penalty because its purpose was to punish. ${ }^{100}$ When the government appealed, the Supreme Court had to decide whether to categorize the additional payment on the basis of its form or its purpose. In overruling the court of appeals and holding that the fifty percent addition constituted a civil sanction, Justice Brandeis' majority opinion took both approaches. The Court implicitly used the formal procedural approach, ${ }^{101}$ but also assessed the statute's purpose:

The remedial character of sanctions imposing additions to a tax has been made clear by this Court in passing upon similar legislation. They are provided primarily as a safeguard for the protection of the revenue and to reimburse the Government for the heavy expense of investigation and the loss resulting from the taxpayer's fraud..$^{102}$

The Court's decision ignored the perception of the legal community and the public that the tax addition was a "fraud penalty" for tax evasion, a severe sanction often sought as an alternative to criminal prosecution. ${ }^{103}$ The opinion rested primarily on the compensatory approach in middleground jurisprudence set out in Stockwell. ${ }^{104}$

99. 303 U.S. at 398. In a subsidiary argument, Mitchell also claimed that the $50 \%$ payment was barred by the doctrine of res judicata. The circuit court rejected this claim on the ground that an acquittal in a criminal case, requiring proof beyond a reasonable doubt, hacl no impact on a civil case in which proof was required only by a preponderance of the evidence. The Supreme Court followed similar reasoning in rejecting this claim. Id. at 397.

100. Mitchell v. Commissioner, 89 F.2d 873, 878 (2d Cir. 1937), rev'd sub nom. Helvering v. Mitchell, 303 U.S. 391 (1938).

101. Justice Brandeis referred to the statutory definition:

That Congress provided a distinctly civil procedure for the collection of the additional 50 per centum indicates clearly that it intended a civil, not a criminal, sanction. Civil procedure is incompatible with the accepted rules and constitutional guaranties goveming the trial of criminal prosecutions, and where civil procedure is prescribed for the enforcement of remedial sanctions, those rules and guaranties do not apply.

303 U.S. at 402.

102. Id. at 401 (footnote omitted).

103. Twenty-five years later, Balter still characterized the $50 \%$ addition as a "penalty." HARRY G. BALTER, TAX FRAUD AND EVASION $\S 8.3$ (3d ed. 1963). The addition is now 75\%. See 26 U.S.C. $\S$ 6653(b)(1) (1988).

104. Referring by implication to the distinction between Boyd and Stockwell, the Court found that the Internal Revenue Code's provision imposing prison sentences and fines for tax evasions appeared under the heading "Penalties," while the 50\% payment appeared in a separate section called "Additions to the Tax." Mitchell, 303 U.S. at 404-05. This ostensibly distinguished certain sanctions from the group of cases in which the Court had found civil penalties to be criminal in nature as a result of the textual connection between prison, fines, and other money sanctions such as forfeiture. $C f$. United States v. Ward, 448 U.S. 242,254 (1980) ("[T]he statute under scrutiny in Boyd listed forfeiture along with fine and imprisonment as one possible punishment for customs fraud, a fact of some significance to the Boyd Court. Here, as previously stated, the civil remedy and the criminal remedy are contained in separate statutes enacted 70 years apart." (citation omitted)). 
Mitchell represented a new limitation on Boyd. ${ }^{105}$ Until Mitchell it had still seemed possible that the Court would expand Boyd's requirement of special procedural rules for the imposition of more-than-compensatory money sanctions. In Mitchell, however, the Court seemingly eliminated the necessity for any special procedures by declaring the money sanction at issue completely civil in character. The Court might have been trapped in its own reasoning: believing that punitive sanctions could not be imposed in the context of civil procedure, ${ }^{106}$ it could not find a punitive purpose in the tax addition for fraud without upsetting the whole legislative arrangement and turning a fifty-percent tax addition into a criminal prosecution.

\section{b. False Claims on the Government}

Shortly after Mitchell, the Supreme Court decided United States ex rel. Marcus v. Hess, ${ }^{107}$ an equally central case in the developing jurisprudence of sanctions. Marcus considered an attack on more-than-compensatory money sanctions for false claims against the government. ${ }^{108}$ In addition to civil and criminal sanctions for false claims, since 1863 federal law has provided civil money sanctions that are not strictly compensatory. ${ }^{109}$ When Marcus arose, the False Claims Act called for violators to forfeit $\$ 2000$ plus double damages

105. Mitchell also presaged the demise of Coffey v. United States, 116 U.S. 436 (1886), in which an acquittal in a criminal case was held to estop a subsequent civil proceeding by the government against the same defendant. In Mitchell, the Court said that the difference in evidentiary standards meant that a criminal acquittal could not foreclose a civil finding of liability. 303 U.S. at 397. Later, in United States v. One Assortment of 89 Firearms, 465 U.S. 354 (1984), the Court specifically repudiated Coffey to the extent that it was inconsistent with this principle. "[N]either collateral estoppel nor double jeopardy," the Court said, "bars a civil, remedial forfeiture proceeding initiated following an acquittal on related criminal charges." Id. at 361 .

106. Justice Brandeis noted: that "Congress may not provide civil procedure for the enforcement of punitive sanctions ...." Mitchell, 303 U.S. at 402 n.6. Later, in Kennedy v. Mendoza-Martinez, 372 U.S. 144 (1963), the Court made an even more sweeping statement while invalidating a statute that automatically revoked the citizenship of Americans who evaded the military draft by remaining outside the country:

[T]his punishment cannot be imposed without a prior criminal trial and all its incidents, including indictment, notice, confrontation, jury trial, assistance of counsel, and compulsory process for obtaining witnesses. If the sanction these sections impose is punishment, and it plainly is, the Id. at 167.

procedural safeguards required as incidents of a criminal prosecution are lacking.

107. 317 U.S. 537 (1943).

108. A false claim is a request for payment, addressed to a government agency, and based on untrue information. Given the enormous variety of government programs and activities from which citizens and corporate entities receive benefits, and given that the beneficiaries of all these programs and activities must make factual representations to the government to obtain payment, the prohibition on false claims applies to millions of transactions involving billions of dollars a year. A false claim on the federal govemment can be prosecuted as a federal crime under statutes dealing with such offenses as conspiracy to defraud the government with respect to claims, 18 U.S.C. $\$ 286$ (1988); false, fictitious, or fraudulent claims, 18 U.S.C. $\$ 287$ (1988); general conspiracy to defraud the United States, 18 U.S.C. \$ 371 (1988); mail fraud, 18 U.S.C. $\$ 1341$ (1988); wire fraud, 18 U.S.C. $\$ 1343$ (1988); and false statements, 18 U.S.C. $\S 1001$ (1988). Each of these prohibitions makes various aspects of the knowing presentation of an untrue claim against governmental funds a criminal offense. False claims also can lead to suits for restitution based on common law doctrines of unjust enrichment and on causes of action arising from breach of contract.

109. The current provision is codified at 31 U.S.C. $\$ 3729$ (1988). 
to the United States. ${ }^{110}$ The defendant in Marcus argued that it was improper to use civil procedures to impose a remedy that was clearly meant to be more than compensatory. Thus, the Court again faced the question whether a money sanction labeled "forfeiture and damages" was a punitive sanction, and if so, whether the defendant could invoke the Double Jeopardy Clause. ${ }^{111}$ The handling of similar issues in an earlier case sheds light on the significance of Marcus' holding.

In an 1893 case, United States v. Shapleigh, ${ }^{112}$ the Eighth Circuit held that the nature of the false claims sanction required the government to meet an evidentiary hurdle higher than the civil law's preponderance standard, reasoning:

The action at bar is a civil suit in form; but when, under the form of this civil suit, the government sought to punish this defendant for felonies by recovering the penalty of double damages and $\$ 2,000$ for each offense, it made this proceeding criminal in its nature and purpose . . . . While civil in form, all its other characteristics were those of a criminal case; its prosecutor was the government; its purpose was punishment; the defendant's conviction of a felony was essential to the plaintiff's recovery; the defendant's character and property were in jeopardy, because the government sought to punish him in this suit; and the verdict and judgment here would be a bar to any criminal prosecution for the same offense. The case became a criminal case under the cloak of a civil suit ....

Wryly questioning the government's view of the civil penalty, the court asked, "Is a wolf in sheep's clothing a wolf or a sheep?"114

Although Judge Sanborn, writing for the court, held that the government would have to prove its civil case beyond a reasonable doubt, no statutory or constitutional language compelled his decision to apply the rules of criminal procedure to a case with a civil label. Instead, the court overrode the legislative label and rejected the government's position, basing its opinion on strongly held ideas about fixed characteristics of criminal and civil law.

The Supreme Court faced this same issue in Marcus, some fifty years later. Writing for the Court, Justice Black drew a completely different picture of the money sanction than was drawn in Shapleigh and offered a compensatory rationale for the false claims money sanction. Citing Mitchell, he concluded: "We cannot say that the remedy now before us requiring payment of a lump

110. Marcus, 317 U.S. at 540.

111. Id. at 548-49.

112. 54 F. 126 (8th Cir. 1893).

113. Id. at 134 .

114. Id. at 130. 
sum and double damages will do more than afford the government complete indemnity for the injuries done it."115

However, the remedial reasoning was no more persuasive in the context of false claims than it had been in the context of tax fraud. Indeed, Justice Black recognized, in dicta, that the sanction had a punitive aspect. Nonetheless, the Marcus Court thought that it could be imposed without implicating the Double Jeopardy Clause or any other protection of criminal procedure. Quoting Day v. Woodworth, Justice Black explained:

This remedy does not lose the quality of a civil action because more than the precise amount of so-called actual damage is recovered. . . . Congress could remain fully in the common law tradition and still provide punitive damages. "By the common as well as by statute law, men are often punished for aggravated misconduct or lawless acts by means of civil action and the damages inflicted by way of penalty or punishment given to the party injured."

Justice Black's reference to Day analogized state-initiated suits for money sanctions to privately initiated suits for punitive sanctions. This analogy allowed the Court to concede that state-invoked sanctions had a punitive effect, yet permit such sanctions to be applied in procedural settings controlled exclusively by civil rules. Justice Black thus widened the growing gap between effect and procedure in the arena of state-invoked punitive civil sanctions. He also reinforced the notion that a middleground jurisprudence existed-lying somewhere between the conventional paradigms of civil and criminal law-where punitive civil sanctions played a prominent role. ${ }^{117}$ Mitchell and Marcus became part of a broader dynamic that transformed the term "remedial" into a catchall label for sanctions that courts did not want to define as punitive in the criminal sense, but that were clearly not simple compensatory damages. By referring to money sanctions as remedial, the Court could approve the use of civil procedures to impose sanctions designed to punish wrongdoers and could

115. United States ex rel. Marcus v. Hess, 317 U.S. 537, 549 (1943) (citation omitted); accord United States v. Bomstein, 423 U.S. 303, 314 (1976) ("Congress intended the double-damages provision lin the False Claims Act] to play an important role in compensating the United States in cases where it has been defrauded.").

116. Marcus, 317 U.S. at 550 (quoting Day v. Woodworth, 54 U.S. (13 How.) 363, 371 (1851)).

117. Rex Trailer Co. v. United States, 350 U.S. 148 (1956), decided shortly after Marcus, raised similar issues. The United States sued Rex under the Surplus Property Act of 1944, which permitted the government to choose between three alternative money sanctions-two labeled "liquidated damages" and a third consisting of double damages plus $\$ 2000$ for each violation of the Act. The Court upheld the statute, this time invoking an analogy to contract rather than tort:

Liquidated damages are a well-known remedy, and in fact Congress has utilized this form of recovery in numerous situations. In all building contracts, for example, Congress has required the insertion of a liquidated-damage clause which "shall be conclusive and binding upon all parties".... Liquidated-damage provisions, when reasonable, are not to be reganded as penalties and are therefore civil in nature.

Id. at 151 (citation omitted); see also supra notes 91-96 and accompanying text. 
send a deterrent message to the community. By finding civil implications in a statute that certainly had punitive meaning for legislators, administrators, and the public, the Court made deft use of a legal fiction to facilitate and legitimate the increased use of punitive sanctions.

\section{Deterrence Approach}

The fourth and final approach-deterrence-explains more-than-compensatory money sanctions as tools of state power used to deter wrongful conduct. It implicitly rejects the formal procedural approach and accepts the view that a civil penalty or a double or triple money sanction is not compensatory in purpose even if imposed in a civil proceeding. On the contrary, under the deterrence approach, the purpose of these sanctions is to impose a cost on wrongdoers that promotes compliance with the law. Authority for this power comes from the general regulatory prerogative of the state and its administrative agencies. That power, this approach reasons, allows the use of more-thancompensatory sanctions without special procedural rules so long as the purpose of the sanction is not punishment. Therefore, critical to this approach is its attempt to distinguish punishment from deterrence.

The Supreme Court addressed the relationship between punishment and deterrence most explicitly in three pivotal cases: Oceanic Steam Navigation Co. v. Stranahan ${ }^{118}$ Atlas Roofing Co. v. Occupational Safety \& Health Review Commission, ${ }^{119}$ and United States $v$. Ward. ${ }^{120}$ A central issue in these cases was whether a more-than-compensatory money sanction could apply in a purely administrative setting. The answer to this question had far-reaching implications for the future path of law enforcement over the broad area of fiscal, economic, and social policy increasingly controlled by administrative agencies. If administrative agencies could assess a penalty without having to go to court, they could take a far more active role in law enforcement.

\section{a. Oceanic Steam Navigation Co. v. Stranahan}

In the leading case raising this issue at the turn of the century, Oceanic Steam Navigation Co. v. Stranahan, the Secretary of Commerce and Labor-acting under express statutory authority-used an administrative procedure to impose a monetary penalty on the appellant for bringing unhealthy immigrants to America. The appellant argued that the penalty was "repugnant to the Constitution because it define[d] a criminal offense and authorize[d] a purely administrative official to determine whether the defined crime has been commit-

118. 214 U.S. 320 (1909).

119. 430 U.S. 442 (1977).

120. 448 U.S. 242 (1980). The Supreme Court also considered this issue implicitly in Helvering v. Mitchell, 303 U.S. 391, 402 (1938) (citing Oceanic Steam Navigation). 
ted, and, if so, to inflict punishment."121 Justice Edward White examined the "context" of the legislation-its language and history-and found an intent to create only a civil sanction:

[The Act's] various sections accurately distinguish between those cases where it was intended that particular violations of the act should be considered as criminal and be punished accordingly, and those where it was contemplated that violations should not constitute crime, but merely entail the infliction of a penalty, enforcible [sic] in some cases by purely administrative action and in others by civil suit. ${ }^{122}$

By relying solely on legislative intent, ascertained from the legislature's procedural choice, Justice White was using the formal procedural strand of middleground jurisprudence. ${ }^{123}$ His reasoning drew from Hepner, which had in turn relied on Stockwell. ${ }^{124}$

Although it did not fully address how punitive sanctions properly fit into the framework of administrative as opposed to criminal law, the Oceanic Steam Court found no defect in the use of the administrative process to assess a money sanction. To require a judicial proceeding would "magnif[y] the judicial to the detriment of all other departments of the Government, disregard[] many previous adjudications of this court and ignore $[$ practices often manifested and hitherto deemed to be free from any possible constitutional question."125 The opinion implied that using a penalty to deter was valid in the instant case because immigration law was an area over which Congress had exclusive legislative powers. Therefore, Justice White did not need to make a blanket determination that all administrative agencies should have this tool at their disposal.

Justice White also stated that the imposition of a more-than-compensatory money sanction did not require the government to use criminal procedure. ${ }^{126}$ Such a sanction could be imposed not only in a judicially managed civil

121. Oceanic Steam Navigation, 214 U.S. at 336. The relevant section of the statute, the Alien Immigration Act of Mar. 3, 1903, ch. 1012, § 9, 32 Stat. 1213, said:

II]f it shall appear to the satisfaction of the Secretary of the Treasury (Secretary of Commerce and Labor) that any alien so brought to the United States was afflicted with such a disease at the time of foreign embarkation, and that the existence of such disease might have been detected by means of a competent medical examination at such time, such person or transportation company ... shall pay to the collector of customs ... the sum of one hundred dollars for each and every violation .... and no vessel shall be granted clearance papers while any such fine imposed upon it remains unpaid ....

The Court called this sanction a "penalty." 214 U.S. at 337.

122. 214 U.S. at 337.

123. See supra Part II.B.2.

124. See supra note 89 and accompanying text.

125. Oceanic Steam Navagation, 214 U.S. at 338.

126. Id. at 337-38. The Supreme Court cited Oceanic Steam Navigation in Lloyd Sabaudo Societa Anonima per Azioni v. Elting, 287 U.S. 329, 334 (1932) (upholding administrative money sanctions and confirming their deterrent nature), and in Helvering v. Mitchell, 303 U.S. 391 (1938) (using compensaîory rationale to deny that addition to taxes for fraud serves deterrence). See also supra Part II.B.3.a. 
proceeding, but also in an administrative proceeding, so long as its purpose was to deter but not punish. This Article later examines whether and to what extent this distinction between punishment and deterrence is valid.

\section{b. Atlas Roofing Co. v. Occupational Safety and Health Review Commis- sion}

The Supreme Court's next test of the validity of the deterrence rationale for money sanctions did not occur until Atlas Roofing. ${ }^{127}$ In addition to the jurisprudence of money sanctions, case law involving the constitutionality of many types of nonmonetary punitive sanctions formed the basis for Atlas Roofing.

The leading case involving a challenge to a nonmonetary sanction as punitive was Kennedy v. Mendoza-Martinez, ${ }^{128}$ holding unconstitutional a civil proceeding for forfeiture of citizenship. In Mendoza-Martinez, the Court integrated its previously fashioned tests of punitiveness in order to create a multidimensional balancing test focusing on congressional intent. Under this test, congressional intent determines the form of the sanction, unless contradicted by such other factors as:

Whether the sanction involves an affirmative disability or restraint, whether it has historically been regarded as a punishment, whether it comes into play only on a finding of scienter, whether its operation will promote the traditional aims of punishment-retribution and deterrence, whether the behavior to which it applies is already a crime, whether an alternative purpose to which it may rationally be connected is assignable for it, and whether it appears excessive in relation to the alternative purpose assigned .....129

One of the criteria-whether a nonpunitive alternative purpose could be assigned to the sanction-would become a frequently used analytic device and eventually would lead to the use of the word "remedial" to characterize many kinds of nonmonetary sanctions that entailed substantial restrictions on freedom. ${ }^{130}$

127. 430 U.S. 442 (1977).

128. 372 U.S. 144 (1963). Appellees were native-born citizens who had left the United States to evade the draft during World War II. An administrative action deprived them of their citizenship without any prior hearing. The Court held that automatic administrative deprivation of citizenship was unconstitutional because "Congress has plainly employed the sanction . . . as a punishment ... without affording the procedural safeguards guaranteed by the Fifth and Sixth Amendments." Id. at 165-66.

129. Id. at 168-69 (footnotes omitted).

130. Mendoza-Martinez relied heavily on Flemming v. Nestor, 363 U.S. 603 (1960). In Flemming, the appellant lost his social security benefits after getting deported for being a Communist. The Court held that it "has not hampered legislative regulation of activities within its sphere of concern, despite the often-severe effects such regulation has had on the persons subject to it." Id. at 616. Thus, the denial of social security benefits was seen as part of a program to regulate the use of social security money, rather than to punish the appellant. The Court found this regulatory authority in the police power of the state. Id. at 613, 615-16. 
The Fifth Circuit incorporated the Mendoza-Martinez multivariate test into the jurisprudence of monetary sanctions in Atlas Roofing, ${ }^{131}$ which presented the issue whether money sanctions could be levied in a purely administrative proceeding without violating the Sixth and Seventh Amendment rights to jury trial. The case was critical because it raised the question in the new legal environment created by the due process revolution. ${ }^{132}$ Could agencies impose penalties through administrative assessment without a jury?

The Fifth Circuit's analysis in Atlas Roofing is a particularly good representation of the deterrent view of more-than-compensatory money sanctions. The Occupational Safety and Health Review Commission had assessed a penalty on Atlas Roofing Company for failing to maintain an adequate railing around an exposed roof bay. ${ }^{133}$ The court confronted the question of whether the penalty "crosses that elusive line between criminal fines-that of necessity require the Sixth Amendment protections-and civil regulatory sanctions-that are left to fall back upon the more amorphous protections of due process." ${ }^{134}$

The Flemming Court, in turn, supported its holding with Hawker v. New York, 170 U.S. 189, 192-93 (1898) (upholding state's denial of medical license because of applicant's past crimes because "[n]o precise limits have been placed upon the police power of a State, and yet it is clear that legislation which simply defines the qualifications of one who attempts to practise [sic] medicine is a proper exercise of that power"), and Ex parte Garland, 71 U.S. (4 Wall.) 333 (1866) (holding that oath requiring affirmation never to have bome arms against United States as condition for practicing law in federal courts void as punishment where applicant was Civil War veteran). Certain sanctions may be experienced as punitive but are not intended as punitive; such sanctions are part of the regulatory power of the state and therefore need not be accompanied by criminal-type procedural rules constitutes the foundation of contemporary jurisprudence justifying substantial restrictions on individual freedom. See United States v. Salerno, 481 U.S. 739 (1987) (upholding pretrial detention of arrestees to prevent future dangerous behavior).

131. 518 F.2d 990, 1011 (5th Cir. 1975). The appeal of this case was joined for hearing with Frank Irey, Jr., Inc. v. Occupational Safety \& Health Review Comm'n, 519 F.2d 1200 (3d Cir. 1974), aff'd on reh' $^{\prime}, 519$ F.2d 1215 (3d Cir. 1975), aff'd sub. nom. Allas Roofing, 430 U.S. 442.

132. Goldberg v. Kelly, 397 U.S. 254 (1970), had imposed new due process requirements on administrative agencies. Consequently, fashioning a concept of due process for administrative agencies became a major challenge for the Court, which set out an interest-balancing test as the key analytic tool for giving or taking away process. See Mathews v. Eldridge, 424 U.S. 319, 335 (1976) (articulating test balancing private interest at stake in governmental decision, governmental interest involved, and value of procedural requirements); see also Washington v. Harper, 494 U.S. 210 (1990) (following Mathews, judicial decision not needed before nonconsensual administration of antipsychotic drugs); Zinermon v. Burch, 494 U.S. 113 (1990) (holding judicial hearing not required when considering hospitalization of person arguably incapable of providing informed consent); Jerry L. Mashaw, The Supreme Court's Due Process Calculus for Administrative Adjudication in Mathews v. Eldridge: Three Factors in Search of a Theory of Value, $44 \mathrm{U}$. CHI. L. REV. 28, 48-54 (1976) (arguing Mathews Court conceived procedural values too narrowly by viewing procedural protection as merely enhancing accuracy and slighted process values of individual dignity, equality, tradition or evolution); cf. Owen M. Fiss, Reason In All Its Splendor, 56 BROOK. L. REV. 789, 795 (1990) ("The decision to begin with Goldberg v. Kelly [in teaching is a] . . systematic confrontational strategy. It is intended to deny the instrumentalism of Mathews v. Eldridge ....").

133. 518 F.2d at 992 . The penalty of $\$ 600$ was assessed under the Occupational Safety and Health Act of 1970 (OSHA), 29 U.S.C. $\$ \$ 651-678$ (1988). Prior to $1990, \$ 666$ (b) provided that any employer committing a serious violation could be assessed a penalty up to $\$ 1000$ for each violation. At that time, $\$ 666$ (a) provided a $\$ 10,000$ penalty for employers who willfully or repeatedly violated OSHA's requirements. In 1990, Congress raised the amounts of the civil penalties to not less than $\$ 5,000$ and not more than $\$ 70,000$ under $\$ 666($ a) and to $\$ 7000$ under $\$ 666($ b). 29 U.S.C.A. $\$ 666$ (West Supp. 1990).

134. 518 F.2d at 994 . 
The Fifth Circuit's analysis of the nature of the penalty focused on one of the Mendoza-Martinez criteria: whether the statute "promotes the traditional aims of punishment, retribution and deterrence."135 The court agreed with the government that because the statute had a deterrent rather than a punitive objective, its purpose should be described as remedial, which "means not only compensatory but a kind of prospective deterrence of [sic] a means to encourage compliance with the government regulation." "136 Once the court found the penalty not punitive, it dismissed the claim that a jury trial was required. ${ }^{137}$ The Fifth Circuit opinion added an important new meaning to the word "remedial" in the context of money sanctions. Rather than using it as compensation for the cost of enforcement, the Fifth Circuit employed the term to implicate the long history of police and regulatory powers of the federal government. These powers could restrict access to benefits and impose sanctions to facilitate desired social ends, but they could not punish. The court called this "prospective deterrence." 138

The Supreme Court upheld the Fifth Circuit's decision and found that an administrative decision on factual issues in statutory penalty cases was constitutionally sufficient. ${ }^{139}$ Without directly addressing the claim that the civil sanction was punitive in purpose, the Court simply assumed that more-than-compensatory money sanctions were a constitutionally valid form of regulation. ${ }^{140}$

Atlas Roofing marked a watershed development in middleground jurisprudence, as the Court affirmed that an administrative penalty imposed for deter-

135. Id. at 1002 (construing Kennedy v. Mendoza-Martinez, 372 U.S. 144, 168 (1963)). said:

136. Id. Even more explicitly admitting the more-than-compensatory nature of the sanction, the Court

And when it comes to the factor of deterrence, the existence of over 200 million citizens most of whom are law abiding and who daily conduct their business and personal affairs without the fear of jail time or being tagged a felon, we know the greater efficacy of the much milder and less potent sanction of loss of license, civil penalties and the like. Id. at 1009 .

137. Id. at 1011-12.

138. Id. at 1002. The Third Circuit's opinion in Frank Irey, Jr., Inc. v. Occupational Safety \& Health Review Comm'n, 519 F.2d 1200 (3d Cir. 1974), was very different. It readily dismissed the claim that the penalty had a punitive purpose, citing Mitchell and Mendoza-Martinez, among others, as dispositive. Id. at 1204-05. In dissent, Judge Gibbons argued that the Supreme Court had approved administrative hearings only where the money sanction resulted from an in rem action, rather than an action in personam. Id. at 1208-09 (Gibbons, J., dissenting). On rehearing, a divided court rejected Judge Gibbons' distinction. Relying on NLRB v. Jones \& Laughlin Steel Corp., 301 U.S. 1 (1937), the court stated that there was no difference "between an administrative award which requires [an employer] to pay a fixed sum of money to certain employees ... and one which orders payment of a civil penalty to the United States." Therefore the Seventh Amendment did not apply. 519 F.2d at 1219 (3d Cir. 1975).

139. 430 U.S. 442 (1977).

140. On the question of whether the Seventh Amendment requires a jury trial, the Court concluded:

[W] hen Congress creates new statutory "public rights," it may assign their adjudication to an administrative agency with which a jury trial would be incompatible, without violating the Seventh Amendment's injunction that jury trial is to be "preserved" in "suits at common law." Congress is not required by the Seventh Amendment to choke the already crowded federal courts with new types of litigation or prevented from committing some new types of litigation to administrative agencies with special competence in the relevant field.

Id. at 455 (footnote omitted). 
rent purposes withstood the new due process requirements. Narrowly read, Atlas Roofing held only that an administrative penalty was valid so long as it claimed a deterrent rather than punitive purpose. ${ }^{141}$ The Court, however, did not clarify the difference between deterrent and punitive objectives. Atlas Roofing also anticipated the enhanced future role of specialized agencies in law enforcement.

\section{c. United States v. Ward}

Atlas Roofing did not signal the end of the Court's use of legal fictions to create a jurisprudence of punitive civil sanctions. In United States $v$. Ward ${ }^{142}$ the Court examined a challenge to a reporting requirement in the Federal Water Pollution Control Act, which provided a civil penalty of up to $\$ 5,000$ for each violation of water pollution control standards. ${ }^{143}$ The appellant claimed that the penalty was punitive and argued that the Act's reporting requirement violated its Fifth Amendment privilege against self-incrimination. Applying the Mendoza-Martinez test, Justice Rehnquist rejected this claim, holding that Congress' use of the label "civil penalty" suggested that it had intended to create a civil sanction. ${ }^{144}$ Given this express indication of intent, the question became whether Congress "nevertheless provided for sanctions so punitive as to 'transfor[m] what was clearly intended as a civil remedy into a criminal penalty.""145 The Court then applied only one of the Mendoza-Martinez criteria and asked whether another statute defined the prohibited behavior as a crime. Dismissing this possibility, the Court went on to reject the very validity of the criterion. Citing other occasions where Congress imposed parallel criminal and civil sanctions, the Court concluded that civil and criminal "sanctions" may apply to the same conduct. Justice Rehnquist then summarily held

141. But $c$. Tull v. United States, 481 U.S. 412 (1987) (Seventh Amendment requires provision of jury trial to defendant in civil suit for collection of penalty assessed by government). The decisions in Atlas Roofing and Tull create a curious anomaly. If Congress chooses an administrative procedure and legislatively cuts off judicial review, an administrative hearing officer will render the decision. If, on the other hand, Congress creates a mechanism whereby the administrative agency has no assessment power but is directed to bring a suit in court for imposition of the penalty, the defendant is entitled not only to a trial, but to a jury trial. Thus, according to Atlas Roofing, Congress can undermine the common law role of the jury in penalty collection procedures by choosing an administrative setting.

142. 448 U.S. 242 (1980). The defendant oil company in Ward reported an oil spill it had caused to the Environmental Protection Agency (EPA). On the basis of this information, an administrative order directed the defendant to pay a $\$ 500$ penalty. The court of appeals found that the civil penalty was punitive in purpose and effect and invalidated the particular administrative proceeding as violative of the Self-Incrimination Clause of the Fifth Amendment. Ward v. Coleman, 598 F.2d 1187, 1190-94 (10th Cir. 1979), rev'd sub nom. United States v. Ward, 448 U.S. 242 (1980).

143. At that time, the statute allowed a civil penalty of $\$ 5000$ for each offense. In 1978 the Act was amended to allow a penalty of up to $\$ 50,000$ for each offense or up to $\$ 250,000$ per offense in cases of willful negligence or misconduct. 448 U.S. at 245 n.4.

144. Id. at 249.

145. Id. (quoting Rex Trailer Co. v. United States, 350 U.S. 148, 154 (1956) (alteration in original)). 
that the appellant had failed to show "that the penalty here in question is punitive in either purpose or effect." 146

None of the Justices in Ward referred to Atlas Roofing. Was it irrelevant that only a few years earlier the Supreme Court had decided that a civil penalty could be deterrent in nature, but nevertheless could be assessed by an administrative agency? No answer is evident. Both decisions held that Congress could validly impose a more-than-compensatory money sanction without special procedural protections, but arrived at that conclusion using two different methods. In Atlas Roofing, the Fifth Circuit interpreted a penalty for violations of OSHA as a deterrent sanction. In Ward, the Court refrained from determining the type of sanction involved. Instead, Justice Rehnquist emphasized congressional intent and used the Stockwell reasoning, in which procedure determined substantive purpose. ${ }^{147}$

After Atlas Roofing, the longstanding practice of administrative fines and penalties became a full-fledged part of Supreme Court jurisprudence, despite the due process revolution. The result was continued growth in the use of administrative agencies as part of the law enforcement establishment. By facilitating the use of civil money sanctions, Atlas Roofing further legitimated the shift of sanctions from the criminal into the civil paradigm, a setting which permitted the imposition of a penalty with an efficiency not attainable in the thickets of criminal procedure.

146. Id. at 251. The Court noted, but did not emphasize, the compensatory purpose of the penalties collected under the Act. They are paid into a "revolving fund" to pay for the "removal, containment, or dispersal of oil and hazardous substances discharged into navigable waters and to defray the costs of administering the Act." Id. at 246 (citing 33 U.S.C. $\$ 1321$ (1976)).

147. The Court extended the Ward approach in United States v. One Assortment of 89 Firearms, 465 U.S. 354 (1984), which decided whether an acquittal in a criminal case barred a subsequent forfeiture suit on grounds of collateral estoppel or double jeopardy. First, the Court held that the determination of factual matters in a criminal trial could not estop a relitigation of those issues in a civil trial because of the differences in the burdens of proof for criminal and civil cases. Id. at 361-62.

Second, to determine whether forfeiture proceedings would be barred by double jeopardy, the Court stated: "The question, then, is whether a $\$ 924$ (d) forfeiture proceeding is intended to be, or by its nature necessarily is, criminal and punitive, or civil and remedial." Id. at 362 . Based on the character and context of the forfeiture proceeding, the Court concluded that "[i]n contrast to the in personam nature of criminal actions, actions in rem have traditionally been viewed as civil proceedings." $I d$. at 363. Congress, in addition, had authorized a summary administrative proceeding. Id. The Court found the scope of substantive coverage in the forfeiture statute larger than in the criminal statute, indicating that the conduct leading to forfeiture was not necessarily criminal in nature. Thus, the Court concluded that the sanction was not criminal and that Congress intended a "civil, not a criminal, sanction." Id. (quotation and citation omitted).

In addition, the Court performed a purpose analysis. Under this test, the Court found forfeiture to be a remedial action because its purpose was to take illegally sold guns out of public circulation as a control measure rather than as a punitive sanction. The forfeiture, said the Court, "plays an important role in furthering the prophylactic purposes of the 1968 gun control legislation by discouraging unregulated commerce in firearms and by removing from circulation firearms that have been used or intended for use outside regulated channels of commerce." Id. at 364. Howevar, this reasoning was flawed. Had the guns been contraband, forfeiture designed to take them out of circulation could properly be interpreted as a prophylactic measure.

Forfeiture proceedings are increasingly criticized because they take property without due process of law. For an analysis of forfeiture and its problems, see Alok Ahuja, Civil Forfeiture, Warrantless Property Seizures, and the Fourth Amendment, 5 YALE L. \& POL'Y REV. 428, 430 \& n.11 (1987). 


\section{The Punitive Nature of More-than-Compensatory Money Sanctions}

Four major lines of reasoning have dominated the Supreme Court's middleground jurisprudence. I have argued that only the first adopts a true functional analysis and that only the first properly connects function and procedure. Courts using the punitive approach view money sanctions as quasi-criminal or punitive in character. Therefore, they impose heightened due process protections.

On the other hand, in the formal procedural approach the Court found a neat historical niche for money sanctions-an old English form of action that was impervious to surrounding extraprocedural issues such as purpose and effect. A functional analysis of the sanction had no place in this approach to more-than-compensatory money sanctions.

The compensatory approach viewed more-than-compensatory money sanctions as a reimbursement to the government for its enforcement costs. By focusing on the revenue-creating aspect of the money sanction, the Court restricted its analysis to an inappropriately narrow aspect of money sanctions. In many instances the civil penalties were relatively small, proportionately similar to what a defendant held liable for breach of contract might pay in liquidated damages. In this sense civil penalties modeled contractual remedies; in both cases the defendant could view the remedy as providing the plaintiff with a return of consequential damages in addition to, but not in place of, a deterrent. ${ }^{148}$ As long as the extra payment did not exceed an amount that could be justified under a consequential damage analysis, there were compelling reasons not to view the penalty as punitive: it kept the penalty within the civil setting and relieved the Court from requiring procedural rules associated with state-invoked punitive sanctions.

The ultimate procedural result of the compensatory approach seems appropriate in the case of penalties that, because of their small size, fit under the liquidated damages rule. Courts or administrative agencies should not be burdened with cumbersome procedural requirements for meting out small regulatory fines. But this does not imply that the compensatory approach is correct. Even where money sanctions are relatively small, an appropriately focused functional analysis should recognize that they are imposed not only to defray costs but also to deter and punish. Multiple purposes and effects characterize money sanctions. The compensatory approach is, thus, a flawed approach to middleground jurisprudence and spawns a fundamental misunderstanding of the nature of sanctions.

A true functional analysis identifies the punitive aspect of these sanctions and thereby considers the necessary procedural implications. Rather than calling the sanction compensatory in order to avoid unwanted procedural requirements, legislatures and courts must develop measures of punitiveness that determine

148. See supra note 91 and accompanying text. 
at what point, on a continuum of increasing punitive severity, to apply heightened procedural protections. Helvering v. Mitchell, which held the fraud sanction in the Internal Revenue Code to be compensatory, asserted in a critical footnote: "Congress may not provide civil procedure for the enforcement of punitive sanctions ...."149 But it is not self-evident that heightened procedural protections would have been required were the sanction called punitive. The procedure required depends not just on whether the sanction is punitive, but also on how punitive it is.

Regardless of the proper conceptual definition, a fundamental strategic enforcement reason justifies recognition of the punitive and deterrent purposes in more-than-compensatory money sanctions. If civil penalties are primarily compensatory, then lawmakers must restrict them to a justifiably compensatory range. By considering deterrence a secondary or indirect consequence of money sanctions, rather than their primary purpose, the compensatory approach relinquishes an important enforcement resource. Conventional ceilings on monetary sanctions have undercut their control power. ${ }^{150}$ Money sanctions have only recently begun to be significant in size; their stunted growth stems in part from the distorted jurisprudence that defined them primarily as compensatory remedies. ${ }^{151}$

According to the deterrent approach, the purpose of more-than-compensatory money sanctions is to suppress wrongful conduct. From this perspective, punishment and deterrence are distinct, the latter constituting a legitimate end of state regulation in civil law settings. Like the punitive approach, the deterrence approach attempts to assess the sanction functionally. Each approach accepts that such sanctions purposely impose a cost to discourage wrongful conduct and facilitate public order. The consequences that flow from labeling the sanction punitive or deterrent, however, are different. If the sanctions are punitive, special procedural protections apply; if the sanctions are deterrent, such protections do not apply. The fictional aspect of the deterrence approach rests on the presumption that one can draw a meaningful distinction between deterrence and punishment in the context of money sanctions.

149. Helvering v. Mitchell, 303 U.S. 391, 402 n.6 (1938).

150. See Richard A. Posner, Optimal Sentences for White-Collar Criminals, 17 AM. CRM. L. REV. 409,417 (1980) (suggesting reliance on monetary fines in cases of white-collar crime, and arguing that "it would seem more efficient to drop the criminal label, and any stigma attached to it, and offset any loss in disutility to the criminal by increasing the size of the civil penalty. In that way, the social revenue can be increased with no loss of deterrence."). But cf. John C. Coffee, Jr., Corporate Crime and Punishment: A Non-Chicago View of the Economics of Criminal Sanctions, 17 AM. CRIM. L. REV. 419, 423 (1980) ("[T]he greater threat associated with incarcerative penalties cannot be efficiently offset simply by increasing the severity of authorized monetary penalties.").

151. An additional reason for rejecting the compensatory approach exists. This approach disregards both the perceived effect of sanctions and institutional explanations for their use-assuming both are punitive-yet justifies the sanctions by reference to their alternative, but secondary, compensatory effect. In this way, the Court undermines the concept of legitimate alternative purpose, which plays a key role in other parts of the law of sanctions. 
While important analytic and practical differences between punitive and deterrent sanctions exist for nonmonetary sanctions, this is not true for monetary sanctions. Suppose a bank director is barred from obtaining a management position for having misappropriated bank funds. Although the disqualification could be considered punitive, it may also be viewed as solely remedial in purpose, a method for protecting bank customers from possible future harm. The regulatory agency imposing such a sanction will be aware that it is punitive for the banker, and a judge may take the punitive effect of such a sanction into account if the banker is also sentenced in criminal court. However, the institutional purpose of the sanction remains protection of the public. ${ }^{152}$

In contrast, it is difficult to view a $\$ 500,000$ civil penalty on the bank director as anything other than punishment. One way to characterize this sanction as remedial is to argue that the money penalty will deter bank officers from engaging in similar wrongful conduct in the future. The idea that monetary sanctions are deterrent and not punitive procedures reduces them in size and prevents lawmakers from setting monetary sanctions at levels that are high enough to exploit the full deterrent potential of a fully developed regime of monetary sanctions. This is not a defensible position, however, for, in the case of monetary sanctions, deterrence is achieved through punishment. It is the pain of having to pay a large fine that deters similar actions in the future. This merging of the ends of deterrence and punishment distinguishes monetary from nonmonetary sanctions. Barring the bank officer from future management positions can be seen as producing solely a remedial effect. The immediate end of the sanction is not punishment, even if the bank officer personally experiences it as punitive. The distinction between punishment and deterrence with regard to more-than-compensatory money sanctions is therefore flawed, for the deterrent effect of monetary sanctions is dependent on their being punitive as well.

As Boyd indicates, viewing monetary sanctions as punitive would not require the Court to invalidate their use in civil settings. ${ }^{153}$ This approach would allow the legislature to exploit the full enforcement potential of these sanctions. But labeling more-than-compensatory money sanctions punitive rather than deterrent would require the increased use of procedural protections. By calling the sanctions deterrent, compensatory, or simply debt collection devices, the Court has avoided developing procedural protections for settings in which punitive sanctions were imposed. Consequently, procedural preference has dictated substance. Abandoning the conventional paradigms would require the

152. See United States v. Bizzell, 921 F.2d 263, 267 (10th Cir. 1990) ("It is the clear intent of debarment to purge govemment programs of corrupt influences and to prevent improper dissipation of public funds. Removal of persons whose participation in those programs is detrimental to public purposes is remedial by definition."); Manocchio v. Sullivan, 768 F. Supp. 814, 817 (S.D. Fla. 1991) (holding defendant convicted of crime could be excluded from participation in federal medicare program: "Disqualifying a person from participating in a social program or practicing a profession because of offensive activity is not punishment, if the past activity is such that the public would have an interest in excluding the offender.").

153. See supra notes 73-77 and accompanying text. 
development of middleground procedure, specifically designed to respond to the punitiveness of middleground sanctions. ${ }^{154}$ From now on I will refer to more-than-compensatory money sanctions as punitive sanctions, in keeping with the foregoing analysis.

\section{The Reemergence of the Punitive Approach}

Until the mid-1980's, the formal procedural, compensatory, and deterrent approaches to more-than-compensatory money sanctions dominated middleground jurisprudence, while the punitive approach had only a small effect on the developing area of middleground sanctions. Although Boyd had not been overturned-and thus the self-incrimination privilege and some Fourth Amendment protections still applied to certain civil proceedings ${ }^{155}$ - very few cases found a punitive or quasi-criminal purpose in money sanctions. The fictional paradigms held sway over functional jurisprudence; the deterrence rationale towered above the punitive rationale. This legal reasoning allowed Congress to expand significantly the use of punitive civil sanctions during this period without acknowledging them as such.

The nature of punitive money sanctions continued to stimulate litigation by those who believed that a purely civil procedural setting for these sanctions violated established legal norms. ${ }^{156}$ But it was not until 1989, in United States v. Halper, ${ }^{157}$ that the Court again employed the punitive approach in defining the character of a civil penalty. Halper arose, like Marcus, ${ }^{158}$ under the civil prong of the False Claims Act, ${ }^{159}$ the revised version of which termed forfei-

154. See infra notes $281-86$ and accompanying text.

155. The doctrinal approach granting heightened procedural protections in cases of punitive civil sanctions had not extended beyond the two major cases, Boyd v. United States, 116 U.S. 616 (1886), and One 1958 Plymouth Sedan v. Pennsylvania, 380 U.S. 693 (1965). However, even these cases had only limited effect because of the increasingly restrictive application of the self-incrimination privilege, Fisher v. United States, 425 U.S. 391 (1976) (privilege no longer applicable to most documents), and the narrow definition of an illegal search, United States v. Leon, 468 U.S. 897 (1984) (reasonable reliance on invalid warrant validates search for purposes of Fourth Amendment). The Court has criticized, but never squarely repudiated, either Boyd or One 1958 Plymouth Sedan. See, e.g., United States v. Ward, 448 U.S. 242, 253 (1980) ("Read broadly, Boyd might control the present case. This Court has declined, however, to give full scope to the reasoning and dicta in Boyd, noting on at least one occasion that '[s]everal of Boyd's express or implicit declarations have not stood the test of time.") (quoting Fisher v. United States, 425 U.S. 391, 407 (1976)).

156. In a key decision signaling a change, Tull v. United States, 481 U.S. 412 (1987), the Supreme Court found that the Seventh Amendment conferred a right to a jury trial in a case where a court had assessed a civil penalty. This was so because the Clean Wate: Act, 33 U.S.C. $\$ \S 1251-1297$ (1988), under which the penalty arose, was intended to allow the district court "to consider the need for retribution and deterrence, in addition to restitution, when it imposed civil penalties." 481 U.S. at 422; see also Erica Clements, Comment, The Seventh Amendment Right to Jury Trial in Civil Penalties Actions: A Post-Tull Examination of the Insider Trading Sanctions Act of 1984, 43 U. MIAMI L. REV. 361 (1988) (use of jury will make for better consideration of policy issues underlying regulation of insider trading).

157. 490 U.S. 435 (1989).

158. 317 U.S. 537 (1943). For a discussion of Marcus, see supra notes $115-17$ and accompanying text.

159. Prior to 1986, the Act provided that a violator was "liable to the United States Government for a civil penalty of $\$ 2,000$, an amount equal to 2 times the amount of damages the Government sustains 
ture a civil penalty. ${ }^{160} \mathrm{Halper}$, the manager of a medical laboratory, had made false claims for reimbursement on sixty-five separate occasions, resulting in an undeserved government payout of $\$ 585$. He was sentenced to two years imprisonment and fined $\$ 5000{ }^{161}$ Following his criminal conviction, the government sued Halper for a civil penalty of approximately $\$ 130,000$. The issue before the Supreme Court was whether imposition of the allowable civil penalty of $\$ 130,000$ after Halper's conviction violated the Double Jeopardy Clause. ${ }^{162}$ The government argued that double jeopardy does not attach in a civil case ${ }^{163}$ because "punishment in the relevant sense is meted out only in criminal proceedings."164 The Court, however, considered the money sanction punitive, overriding congressional intent that the penalty be treated solely as a civil sanction. ${ }^{165}$

The Court's phrasing of the operative question in Halper revealed its perspective on civil money penalties. It asked whether the size of the penalty was so disproportionate to the government's actual damage that it had to be called punitive. The very question presumed that a large differential between the amount of damage caused and the size of the civil penalty imposed rendered the sanction punitive. Although the Court gave the government the opportunity to prove that actual damages were at least close to $\$ 130,000,{ }^{166}$ it ultimately held that, without such proof, the disparity was so great on its face that the penalty constituted a second punishment and thus was barred by the Double Jeopardy Clause. ${ }^{167}$ The Court said: "[A] civil sanction that cannot fairly be said solely to serve a remedial purpose, but rather can only be explained as also serving either retributive or deterrent purposes, is punishment, as we have come to understand the term."168

In offering this rationale for viewing the civil penalty as punitive, the Court clothed a significant departure from its previous holdings in the guise of deference to long-established precedent. Justice Blackmun said, "It is commonly understood that civil proceedings may advance punitive as well as remedial

because of the act of that person and costs of the civil action." 31 U.S.C. $\$ 3729$ (a) (1982), superseded by 31 U.S.C. $\$ 3729$ (a) (1988).

160. In early cases arising under the False Claims Act, the Court regarded payment as a forfeiture rather than a penalty. The Court viewed this as an indication of the Act's civil rather than criminal nature. See Rex Trailer Co. v. United States, 350 U.S. 148 (1956); Marcus, 317 U.S. 537; Helvering v. Mitchell, 303 U.S. 391 (1938).

161. This prosecution was based on the criminal False Claims Act, 18 U.S.C. $\S 287$ (1988).

162. U.S. CONST. amend. V ("NN]or shall any person be subject for the same offence to be twice put in jeopardy of life or limb . . . ."); see also One Lot Emerald Cut Stones v. United States, 409 U.S. 232 (1972); Rex Trailer Co., 350 U.S. 148; Marcus, 317 U.S. 537; Mitchell, 303 U.S. 391.

163. United States y. Halper, 490 U.S. 435,441 (1989).

164. Id. at 447.

165. Id. ("[T]he labels 'criminal' and 'civil' are not of paramount importance.").

166. The Court remanded the case to the district court to give the government a chance to prove its actual costs in conducting the enforcement action. Id. at 452.

167. Id.

168. Id. at 448 . 
goals . . . ."169 However, the Court had not grounded its previous holdings on the proposition that punishment was a legitimate end of the state-invoked civil process. Only Boyd and its scarce progeny, the precedential vitality of which had been limited by competing doctrine, had deemed civil penalties punitive. Generally, the Court had sidestepped the issue of whether a civil sanction was punitive, had called it deterrent, or had found the sanction purely remedial. The Court had frequently indicated that state-invoked punishments were inappropriate in civil procedural settings. Perhaps this is why Justice Blackmun cited no authority for his proposition other than cases involving privately invoked punitive sanctions. His claim that it was common to view more-than-compensatory money sanctions as punitive was similarly unfounded. In fact, the notion that the state could impose punitive sanctions in civil proceedings had become increasingly questionable before Halper.

Halper represents what may be a resurrection of the punitive approach. Halper's framework defines the critical issue as whether the money penalty is disproportionate to the amount of actual damage. Where the court finds disproportion, the money sanction is considered punitive, and the Double Jeopardy Clause applies. ${ }^{170}$ However, this analysis does not end the use of the compensatory or deterrent approaches, for where money sanctions are not disproportionate to the damage caused, the Court has indicated that it will continue to follow one of the other rationales for permitting and justifying money sanctions. In this sense, Halper goes only part of the way toward accepting the punitive function of more-than-compensatory money sanctions.

Under Halper's proportionality standard, the Court must distinguish between punitive and compensatory sanctions in order to determine whether the Double Jeopardy Clause applies. This analytic assessment is similar to deciding which punitive sanctions are so punitive as to require special due process rules - the equivalent question in a regime that recognized all more-thancompensatory money sanctions as punitive sanctions. Thus, Halper has properly focused on the fundamental jurisprudential issue: what is the degree of punitive-

169. Id. at 447.

170. For an application of Halper, see, United States v. 33 Whalers Cove Drive, 954 F.2d 29 (2d Cir. 1991). In that case the court said:

[O]therwise proper forfeiture actions may have the collateral effect of deterring future drug offenders. This fact alone will not render a particular forfeiture punitive in nature. Rather, Halper requires us to examine whether the forfeiture at hand is fully justified by the civil and remedial purposes it ostensibly serves, or whether it or a portion thereof can be explained only with reference to punitive goals. . . . Where the seized property is not itself an instrumentality of crime, however, and its total value is overwhelmingly disproportionate to the value of controlled substances involved ...., there is a rebuttable presumption that the forfeiture is punitive in nature.

Id. at 36 (citation omitted). Although the Court found the sanction to be punitive, under the dual sovereignty exception, it was not barred by the Double Jeopardy Clause. See also Lynn C. Hall, Note, Crossing the Line Between Rough Remedial Justice and Prohibited Punishment: Civil Penalty Violates the Double Jeopardy Clause, 65 WASH. L. REV. 437 (1990). 
ness required for state-invoked punitive civil sanctions to trigger heightened due process, and what are the indicators of such punitiveness?

For the first time since Boyd, the Court fully legitimated the principle that punishment is a proper purpose of a state-invoked sanction in a civil procedural setting. In holding unequivocally that the government may use civil process to impose punitive sanctions, the Halper Court laid to rest the question of whether only criminal sanctions have explicitly punitive ends. ${ }^{171} \mathrm{Now}$, a civil penalty so disproportionate to the damage caused that it can no longer carry the label "remedial" is permissible on the condition that the government has not sought criminal penalties first. ${ }^{172}$ Without a prior criminal conviction, it appears that the $\$ 130,000$ civil penalty would have been upheld as a constitutionally legitimate exercise of state law enforcement authority. ${ }^{173}$ By calling the civil penalty punitive, the Court may have removed the inhibiting effect on sanction size and freed up tremendous enforcement power.

Halper may fundamentally change the relationship between purpose and procedure. If a finding of punitiveness implicates the Double Jeopardy Clause, will it also implicate other due process rights? The Court was silent on this question, but Halper may lead to the conclusion that defendants in punitive civil cases brought by the state are entitled to some or modified criminal procedural protections. Thus, it could open the door for a new middleground jurisprudence with a distinctive procedural content. However, the case might also constitute another step toward the Court's acceptance of only minimal procedural protections in the context of increased punitiveness. In addition, Halper could be read narrowly to permit imposition of much larger penalties in administrative settings, following Atlas Roofing. Although Halper requires the government to forego a parallel criminal prosecution, it may allow the imposition of punitive sanctions with no more than conventional administrative procedural protections. The open question, then, is whether Halper represents a stage in the erosion of due process requirements for the imposition of punitive sanctions or the beginning of a heightened due process standard.

171. The subjective experience of the sanctioned person is not the recognized standard for such an inquiry because it might convert every remedy into a punishment. The question instead focuses on the objective symbolic communication or the objective effect of the sanction. See Halper, 490 U.S. at 447 n.7.

172. Id. at 450 ("Nothing in today's ruling precludes the Government from seeking the full civil penalty against a defendant who previously has not been punished for the same conduct, even if the civil sanction imposed is punitive.").

173. This finding raises concern, not because the civil sanction is more than compensatory, but because it may be disproportionate to the seriousness of the wrongful behavior that it punishes, thus violating due process principles. In punitive cases, the correct measure of sanctions is the seriousness of the wrong, not the extent of the damage. In Browning-Ferris Industries v. Kelco Disposal, Inc., 492 U.S. 257 (1989), the Court acknowledged that Halper implied that the Eighth Amendment might constrain punitive damages awarded to the government in a civil action. Id. at 275 n.21. However, the Court held that the Amendment placed no such constraints on punitive damages awarded in private civil actions. Id. at 275-76; see also Harmelin v. Michigan, 111 S. Ct. 2680 (1991) (upholding mandatory term of life in prison without parole for possessing more than 650 grams of cocaine as not significantly disproportionate to crime committed). 


\section{The Increased Role of Punitive Civil Sanctions Explained}

Legislative adoption of punitive civil sanctions-multiple damages, forfeitures, and penalties-grew rapidly during the middle of the century and has continued to expand in recent years. ${ }^{174}$ In 1979 , Colin Diver found that twenty-seven federal departments and independent agencies enforced 348 civil statutory penalties. ${ }^{175}$ Since that time, Congress has added new punitive civil sanctions, increased their size, and made their imposition procedurally easiex. ${ }^{176}$ Not only are there many new statutes on the books, but administrative agencies also tend to impose sanctions rather than refer cases for criminal prosecution. ${ }^{177}$ Several factors have contributed to the rapid development of punitive civil sanctions. These include a changed philosophy of sanctioning, the general expansion of sanctioning, the growth of the administrative state, and reforms in procedural rules.

174. For some specific applications of punitive civil money sanctions as they developed prior to 1980 see Walter Gellhorn, Administrative Prescription and Imposition of Penalties, 1970 WASH. U. L.Q. 265; Judah Gribetz \& Frank P. Grad, Housing Code Enforcement: Sanctions and Remedies, 66 COLUM. L. REV. 1254 (1966); Alexander Kovel, A Case for Civil Penalties: Air Pollution Control, 46 J. URB. L. 153 (1969); Charlotte P. Murphy, Money Penalties-An Administrative Sword of Damocles, 2 SANTA CLARA LAW. 113 (1962); Turlough O'Brien, Comment, The Use of Civil Penalties in Enforcing the Clean Water Act Amendments of 1977, 12 U.S.F. L. REV. 437 (1978); $c f$. Chris W. Halling, Note, The Federal False Claims Act: A "Remedial" Alternative for Protecting the Government from Fraudulent Practices, 52 S. CAL. L. REV. 159, 175 (1978) ("The Supreme Court's occasional view that the False Claims Act is 'penal' derives not from a reasoned conclusion that the purpose of the Act's civil remedy is primarily punitive, but from the mere historical coincidence that the Act incorporates the lariguage of a criminal statute. In contrast, the Supreme Court has recognized in numerous instances that the False Claims Act is "remedial and imposes a civil sanction."').

175. Colin S. Diver, The Assessment and Mitigation of Civil Money Penalties by Federal Administrative Agencies, 79 CoLUM. L. REV. 1435, 1438 (1979). After studying the civil penalty for the Administrative Conference of the United States, Diver wrote, over a decade ago: "[I]n the past decade the civil fine has assumed a place of paramount importance in the compliance arsenal of federal regulators. Indeed, it is today almost inconceivable that Congress would authorize a major administrative regulatory program without empowering the enforcing agency to impose civil monetary penalties as a sanction." Id. at 1436 (footnote omitted).

176. For analysis of the use and growth of civil penalties, see Erwin Chemerinsky, Controlling Fraud Against the Government: The Need for Decentralized Enforcentent, 58 NOTRE DAME L. REV. 995 (1983) (describing need to relieve Department of Justice of primary enforcement responsibility for fraud against govemment, recommending grant of broad administrative authority and right to private enforcement); Richard P. Kusserow, Civil Money Penalties Law of 1981: A New Effort to Confront Fraud and Abuse in Federal Health Care Programs, 58 NOTRE DAME L. REV. 985 (1983) (applauding law as efficient punitive remedy to counter rampant fraud against government); Eric $M$. Zolt, Deterrence via Taxation: A Critical Analysis of Tax Penalty Provisions, 37 UCLA L. REV. 343 (1989) (Congress views tax penalties as increasingly attractive; author criticizes them as inefficient).

177. In 1981, the General Accounting Office (GAO) conducted a study of fraud committed against government agencies by persons receiving benefits from them and by agency employees, and concluded that administrative sanctions greatly outweigh criminal prosecutions. 1 GENERAL ACCOUNTING OFFICE, FRAUD IN GOVERNMENT PROGRAMS: HOW EXTENSIVE IS IT?: HOW CAN IT BE CONTROLLED? 28, 34, 36 (1981). Despite data from agencies indicating a proportionately greater use of civil rather than criminal sanctions for acts assumed to be criminal in character, recent oversight studies such as those conducted by the GAO and congressional committees indicated their support for expanded use civil monetary sanctions. Id. at v-vi. 


\section{A. The Changing Philosophy of Sanctioning}

At the outset of this Article, I argued that in their paradigmatic forms, criminal and civil law serve different purposes: the former punishment, the latter compensation. ${ }^{178}$ Changing perceptions of the nature of law, starting with Beccaria on the Continent and Bentham in England, began to force a revision in the conventional bifurcation between punishment and compensation. ${ }^{179}$

Among Bentham's contributions, which would profoundly affect the law of sanctions, was the introduction of utilitarian theory into jurisprudence, moving law away from Kantian ideas of metaphysical imperatives. This gradual shift replaced notions of right and desert with concepts rooted in behavioral science. ${ }^{180}$ Utilitarianism became the basis of a legal theory in which the object of the law was to manipulate pain and pleasure to achieve the greatest good. It was this understanding of law as manipulating behavior that bridged the gap between criminal and civil law.

Utilitarian philosophy contributed greatly to deterrence theory, which encouraged the use of middleground punitive sanctions. ${ }^{181}$ The two axioms of deterrence ideology held that the more severe the sanction, the greater its deterrent effect, ${ }^{182}$ and that deterrent effect varied directly with the probability of a sanction's actual application. This perspective viewed the obligation to pay an injured party as a disincentive to causing injury, rather than as a form of

178. Supra notes 1-6 and accompanying text. Until at least the end of the 11th century, criminal and civil law were not clearly identifiable in England; a single, unified sanctioning system achieved both compensation and punishment. 2 HOLDSWORTH, supra note 25, at 43; see also Browning-Ferris Indus. v. Kelco Disposal, 492 U.S. 257, 272 (1989) ("[T] distinction between civil and criminal law was cloudy (and perhaps nonexistent) at the time of Magna Carta.").

The conventional paradigms began to develop as the King gained control over the criminal law, and as tort law emerged as a separate branch. The paradigm of civil law as purely compensatory and the hybrid punitive civil sanction developed through the writ of trespass. This writ had the character of a civil action, not because of its monetary remedy (for purely criminal cases also carried fines), but because it was distinguished in purpose, as well as in procedural form, from criminal prosecution. CARLETON K. ALLEN, LEGAL DUTIES 225-26 (1931). Only after the 17th century did negligence become the main form of tort liability. See generally Hall, supra note 28 , at 967.

179. See Cesare B. Beccaria, AN ESSAY ON CRMMES AND Punishment (London, E. Hodson, 5th ed. 1801); JEREMY BENTHAM, AN INTRODUCTION TO THE PRINCIPLES OF MORALS AND LEGISLATION (Laurence J. Lafleur ed., Hafner Publishing 1948) (1789). Dicey wrote that "from 1825 onwards the teaching of Bentham [1748-1832] exercised so potent an influence that to him is fairly ascribed that thorough-going though gradual amendment of the law of England." A.V. DICEY, LECTURES ON THE RELATION BETWEEN LAW AND PUBLIC OPINION DN ENGLAND DURING THE NINETEENTH CENTURY 125 (1905).

180. "Nature," said Bentham, "has placed mankind under the governance of two sovereign masters, pain and pleasure. It is for them alone to point out what we ought to do, as well as to determine what we shall do." BENTHAM, supra note 179 , at 1 .

181. On the evolution of this theory, see WILLIAM M. LANDES \& RICHARD A. POSNER, THE ECONOMIC STRUCTURE OF TORT LAW 6 (1987) ("[T]he explicitly economic analysis of torts, began in 1961 ... . The germ of the analysis is Bentham's proposition that people maximize utility in all areas of life.").

182. BECCARLA, supra note 179 , at $94-98$. This assumption could be limited by a competing principle: fundamental values of human dignity act as obstacles to increasing severity beyond a certain point, even though a greater deterrent effect may be obtained by more severe remedies. 
compensatory justice. ${ }^{183}$ Where damages failed to promote better behavior, the solution arguably was to augment the size of the civil money payment.

With the development of deterrence ideology, the difference between the purposes of criminal and civil law decreased. ${ }^{184}$ While prominent differences remained with respect to other aspects of the paradigms, such as the elements of the criminal offense or the cause of action, with respect to sanctions the results for criminal and civil defendants became increasingly similar. ${ }^{185}$ Differences in severity, found within criminal and civil law as well as between the two, came to be understood as a matter of quantity rather than quality. This idea contradicted basic normative differences in the conventional paradigms, in which punishment had been distinctive to the criminal process.

Utilitarianism thus brought jurists and scholars to a new awareness of the middleground; the theory highlighted the possibility of controlling parties by placing costs on them in the civil law. The awareness of this possibility coincided with the development of tort law as a form of legitimate coercion rather than as a legal tool for righting a wrong through compensation. ${ }^{186}$ With further integration of utilitarianism into legal analysis, economic theories of law came close to eliminating all differences between civil and criminal law. Within that analytic framework, both civil and criminal law create negative sanctions for wrongful behavior. Posner put it this way:

In cases where tort remedies are an adequate deterrent, because optimal tort damages, including any punitive damages, are within the ability to pay of the potential defendant, there is no need to invoke criminal

183. Hall, supra note 28 , at 758 ('[Bentham's] analysis constituted a radical repudiation of the traditional distinction between compensation and punishment. For Bentham, all sanctions were 'evils'-the only difference was in the degree of evil or pain imposed."). Austin was one of the strongest advocates of the idea that the sanctions in criminal and civil law were the same. "Quite persuasively he [Austin] pointed out that the paramount end of redress is prevention, no less than that of punishment, even though the immediate object is compensation to the injured person." Id. at 759.

184. Id. at 753 ("American legal scholarship, beginning particularly with the publication of Holmes' Common Law, has stressed the prospects of important scientific development by implying an underlying unity in the law of crimes and of torts.").

185. Professor Reich collapses the differences among sanctions altogether, thereby completely undermining the meaning of punishment. Charles A. Reich, Beyond the New Property: An Ecological View of Due Process, 56 BROOK. L. REV. 731, 743 (1990) ("Today ... exclusion is a punishment of such severity that it seems worse than the punishment we mete out to those who break the law.").

186. See generally RICHARD A. POSNER, ECONOMIC ANALYSIS OF LAW (3d ed. 1986). Posner writes: Maintaining the credibility of the tort system requires that if a defendant is found liable he must pay damages .... There are two reasons why compensatory damages must indeed be paid to the victim and not the state. The first is to give the victim an incentive to sue, which is essential to the maintenance of the tort system as an effective deterrent to negligence. The second is to prevent victims from taking too many precautions.

Id. at 176. Economic theory of law suggests increasing damages until they become punitive before using the criminal law. Damages, punitive damages, and the criminal law lie on a scale of deterrence, reserving the most severe sanction for situations in which punitive civil damages fail. See generally ROBERT COOTER \& THOMAS ULEN, LAW AND ECONOMICS (1988); Jules L. Coleman, The Economic Analysis of Law, in NOMOS XXIV: ETHICS, ECONOMICS, AND THE LAW 83 (J. Roland Pennock \& John W. Chapman eds., 1982); William M. Landes \& Richard A. Posner, The Positive Economic Theory of Tort Law, 15 GA. L. REv. 851 (1981). 
penalties ... . The criminal ( = tortious) conduct probably will be deterred .... [C]riminal sanctions generally are reserved, as theory predicts, for cases where the tort remedy bumps up against a solvency limitation. ${ }^{187}$

As the purposes of civil and criminal sanctions came to be understood as similar, so did the purposes of civil and criminal law generally. Civil law could more often achieve what, under the conventional paradigms, would have been conceived as a task for the criminal law. Deterrence ideology, with its philosophical background of law and economics, became a significant causal factor in the growth of punitive civil sanctions.

\section{B. The General Expansion of Sanctioning}

The expansion of punitive civil sanctions is part of a more general phenomenon that has characterized law in recent history. There has been a constant search for new ways to achieve social ends through the legal system. During the eighteenth and nineteenth centuries, courts and legislatures broadened the scope of cognizable causes of action by providing legal remedies for increasing numbers and types of harms. ${ }^{188}$ This was the period when trespass on the case turned into a general action of negligence, and when the field of torts became an independent area of civil law. At the same time, legislatures increasingly relied on the criminal law: they criminalized more forms of behavior and provided new procedural devices for bringing defendants within the scope of the criminal sanction. ${ }^{189}$ The general expansion of legal remedies is closely connected to two prominent themes in civic life: the changing perception of what constitutes wrongful conduct and the notion that formal legal process is a vital resource for protecting the public.

An example of this new view is presented in the 1986 amendment to the False Claims Act, which addresses virtually all fraud committed on the govern-

187. POSNER, supra note 186 , at 205.

188. For a general description of this phenomenon, see LAWRENCE M. FRIEDMAN, TOTAL JUSTICE (1985) (describing "law explosion" in United States).

189. For an analysis of the expansion of the criminal law, see ALLEN, supra note 43, at 4-5 (striking expansion of criminal law leads to overburdening of criminal justice system); Norman Abrams, Criminal Liability of Corporate Officers for Strict Liability Offenses-A Comment on Dotterweich and Park, 28 UCLA L. REV. 463, 476 (1981) (strict liability as well as "corporate responsibility or standard of care approach" allows impasition of criminal responsibility on corporate officers in undeserved situations); Harry V. Ball \& Lawrence M. Friedman, The Use of Criminal Sanctions in the Enforcement of Economic Legislation: A Sociological View, 17 STAN. L. REV. 197 (1965); Glenn A. Clark, Note, Corporate Homicide: A New Assault on Corporate Decision-Making, 54 NOTRE DAME LAW. 911 (1979); Gilbert Geis \& Thomas R. Clay, Criminal Enforcement of California's Occupational Carcinogens Control Act, 53 TEMP. L.Q. 1067 (1980); Sanford H. Kadish, Some Observations on the Use of Criminal Sanctions in Enforcing Economic Regulations, 30 U. CHI. L. REV. 423 (1963); Francis B. Sayre, Public Welfare Offenses, 33 ColUM. L. REV. 55 (1933). 
ment. ${ }^{190}$ The Senate Report on the amendment stated: "Evidence of fraud in Government programs and procurement is on a steady rise. ... Fraud permeates generally all Government programs ranging from welfare and food stamp benefits, to multibillion dollar defense procurements, to crop subsidies and disaster relief programs."191 To respond to these newly perceived threats, the amendment increased the severity of both criminal and civil remedies. ${ }^{192}$

The general expansion of sanctioning also affected and enlarged the middleground. In addition to passing legislation to augment the powers of the Department of Justice and administrative agencies to impose penalties, Congress has also increased the resources of the private sector to bring punitive cases. The courts have read this legislation very broadly. The expansion of private punitive civil sanctions has helped to create a receptive atmosphere for punitive civil sanctions generally. The RICO statute, which predated some of the most important new state-invoked punitive sanctions, is the quintessential example. ${ }^{193}$ There Congress converted entire sections of the federal criminal code into civil wrongs as a way to enforce existing substantive law. Under RICO, civil and criminal offenses are identical in every way except procedurally. ${ }^{194}$

In addition, the Supreme Court has fostered an atmosphere of increased acceptance of punitive civil sanctions by recognizing a greater role for private punitive sanctions. ${ }^{195}$ The Court has rejected challenges to the size of punitive damage awards and upheld the broad discretion of state juries to determine the

190. False Claims Amendment Act of 1986, Pub. L. No. $99-562,100$ Stat. 3153 (codified as amended in scattered sections of 31 U.S.C. (1988)).

191. S. REP. No. 345, 99th Cong., 2d Sess. 2 (1986), reprinted in 1986 U.S.C.C.A.N. 5266, 5267 (footnote omitted).

192. The amendment increased the maximum criminal fine from $\$ 10,000$ to $\$ 1$ million, and the maximum prison sentence from 5 to 10 years. 18 U.S.C. $\$ 287$ (1988). It increased the maximum civil penalty from double to triple the amount of the injury caused to the federal government, 31 U.S.C. $\$ 3729$ (a) (1988), and extended the coverage of the Act to false claims made to federal grantees. 31 U.S.C. $\$ 3729$ (c) (1988). The amended Act also responded to the allegation that procedural rules restricting the imposition of sanctions were hampering law enforcement efforts. 31 U.S.C. $\$ 3730$ (1988). Finally, it streamlined the imposition of civil money penalties by establishing an administrative procedure for imposing civil penalties. 31 U.S.C. $\$ 3730$ (c)(5) (1988). Parallel to the judicial determination of a penalty, agencies could assess penalties of up to $\$ 5000$ per violation, plus up to two times the amount of damage caused. 31 U.S.C. $\$ 3802$ (1988). This change added flexibility to the civil sanctions, though it remains unclear why a judicial procedure is required for assessment of a penalty of $\$ 10,000$ plus multiple damages, while an administrative procedure suffices for imposition of a penalty of $\$ 5000$ plus multiple damages.

193. The RICO statute was enacted as part of the Organized Crime Control Act of 1970, 18 U.S.C. $\$ 1964(\mathrm{c})$ (1984). Section 1964(c) provides for a punitive civil treble-damage sanction in a large range of criminal offenses. Private plaintiffs have used this statute primarily against legitimate businesses in cases of large scale, intentional frauds. A recent Supreme Court decision, however, may portend a decrease in such actions. Holmes v. Securities Inv. Protection Corp., 60 U.S.L.W. 4225 (U.S. Mar. 24, 1992) (holding that $\$ 1964(\mathrm{c})$ requires showing that predicate offense is proximate cause of plaintiff's injury). For a description of the widespread use of RICO in cases of business crime, see G. Robert Blakey, The RICO Civil Fraud Action in Context: Reflections on Bennett v. Berg, 58 NOTRE DAME L. REV. 237 (1982); see also Sedima, S.P.R.L. v. Imrex Co., 473 U.S. 479, 506 (1985) (Marshall, J., dissenting) (recognizing increasing use of civil RICO against legitimate businesses in cases of fraud).

194. See supra note 21 ; see also infra note 213.

195. See Pacific Mut. Life Ins. Co. v. Haslip, i11 S. Ct. 1032, 1066 (1991) (observing "explosion" in size and frequency of punitive damage awards) ( $O^{\prime}$ Connor, J., dissenting). 
amount of punitive damages for private plaintiffs, strengthening the role of punitive civil sanctions in law enforcement and encouraging actions that are, in effect, private criminal proceedings. For example, in Pacific Mutual Life Insurance Co. v. Haslip, the Court affirmed a punitive civil money judgment larger than the potential criminal fine for the same conduct. ${ }^{196}$ The award was more than four times the amount of compensatory damages and more than twohundred times plaintiff's out-of-pocket expenses. At the time of its decision, Haslip commanded widespread attention, for it raised the possibility that the Court would limit jury discretion over punitive awards on due process grounds-a possibility that has significantly diminished. ${ }^{197}$ Although it is unclear how much private punitive damage awards have grown in frequency and size, their increased use and the Court's recent affirmation of broad jury discretion reflect a supportive milieu and are likely to contribute to their expansion. ${ }^{198}$

\section{The Growth of the Administrative State}

The growth of the administrative state has played a central role in the increased use of punitive civil sanctions. ${ }^{199}$ Its expansion has developed along two lines: (1) the congressional decision to provide for punitive civil sanctions initiated by an administrative agency rather than for criminal prosecution, and (2) the increasingly frequent use of administrative as opposed to judicial assessment of civil penalties. Both aspects are part of the general trend toward lowering procedural barriers to the imposition of sanctions: any civil process is less burdensome than the criminal process, and administrative assessment is less burdensome than judicial assessment.

As Congress developed new ways to control wrongful behavior, it created new institutional settings for the new powers. The authority of administrative agencies to initiate proceedings for punitive civil sanctions almost always appears in regulatory statutes. Such sanctions, in turn, have come to be one of the main enforcement procedures of administrative agencies. Undoubtedly, the

196. Id. at 1032.

197. The Court declined to hold that punitive damages awards could never violate due process, finding instead that the particular award at issue passed constitutional muster. However, the scrutiny the Court gave the award in this particular case was so generous that few punitive damages awards are likely to be struck down in the future. Id. at 1035. See also Browning-Ferris Indus. v. Kelco Disposal, Inc., 492 U.S. 257 (1989).

198. Haslip, 111 S. Ct. at 1032. But cf. Stephen Daniels \& Joanne Martin, Myth and Reality in Punitive Damages, 75 MINN. L. REV. 1, 33 (1990) ("Contrary to the rhetoric of the reformers, punitive damages were not routinely awarded during the early 1980's in the sites we examined. At its highest level, the punitive damage rate never exceeded one-quarter of all successful cases or one-fifth of all cases."); Malcolm E. Wheeler, The Constitutional Case for Reforming Punitive Damages Procedures, 69 VA. L. REV. 269, 271 n.6 (1983) ("It appears that only one reported appellate court decision before 1970 upheld an award of punitive damages in a product liability case.").

199. See Robert L. Rabin, Federal Regulation in Historical Perspective, 38 STAN. L. REV. 1189, 119196 (1986). 
vast growth in penalty powers is intertwined with the rise of administrative agencies since the late nineteenth century. ${ }^{200}$

Historically, administrative agencies were not routinely authorized to impose money penalties. ${ }^{201}$ Whereas the agencies responsible for fiscal matters received this power early on, and the Department of Justice was given authority to bring a civil suit for double damages under the 1863 False Claims Act, many other agencies did not initially have this power. For example, when Congress established the Federal Trade Commission (FTC) in 1914, the Commission was not authorized to initiate suits for civil penalties. ${ }^{202}$ Only in 1975 did Congress give the FTC penalty power by granting it authority to initiate judicial proceedings for the imposition of a penalty. ${ }^{203}$ In recent years, Congress has steadily increased both the number of departments and agencies vested with regulatory authority and their powers to seek penalties. ${ }^{204}$

When the Supreme Court upheld the administrative procedure for assessing civil penalties in Atlas Roofing and reasserted the validity of administratively initiated court suits in $\mathrm{Ward}^{205}$ it left Congress free to extend the enforcement powers of administrative agencies by granting them further penalty power. ${ }^{206}$ Responding to reports that the government was not prosecuting a large proportion of medicare and medicaid fraud cases, ${ }^{207}$ Congress empowered the Secretary of the Department of Health and Human Services to impose a civil money penalty of up to $\$ 2000$ for each fraudulent claim plus twice the amount claimed. ${ }^{208}$

Congress has also increased the authority of the Securities and Exchange Commission (SEC) to seek punitive sanctions. The Insider Trading Sanctions Act of 1984 created a new securities fraud enforcement mechanism, authorizing the SEC to bring suit in federal district court for a civil penalty of treble the profit gained or loss avoided in securities trading based on inside information. ${ }^{209}$ As in other instances, Congress passed this act on the assumption that

200. See STEPHEN G. BREYER \& RICHARD B. STEWART, ADMINISTRATIVE LAW AND REGULATORY POLICY 20-31 (3d ed. 1992).

201. Money penalties could be imposed by administrative agencies directly, or by authorizing them to bring actions in federal court.

202. See ROBINSON ET AL., supra note 54 , at $456-57$.

203. The focal point of FTC power is $\S 5$ of the Federal Trade Commission Act, 15 U.S.C. $\$ 45$ (1988), which prohibits "unfair methods of competition in or affecting commerce, and unfair or deceptive acts or practices in or affecting commerce." See also ROBINSON ET AL., supra note 54, at 552-55.

204. An exception was the much celebrated dissolution of the Civil Aeronautics Board. See RoBINSON ET AL., supra note 54, at 8-9.

205. See United States v. Ward, 448 U.S. 242 (1980); Aslas Roofing Co. v. Occupational Safety \& Health Review Comm'n, 430 U.S. 442 (1977); supra Part II.B.4.b-c.

206. For example, Congress significantly extended administrative civil penalty authority in the Civil Monetary Penalties Act of 1981, 42 U.S.C. \$ 1320a-7a (1988).

207. See S. REP. No. 139, 97th Cong., 1st Sess. 462 (1981), reprinted in 1981 U.S.C.C.A.N. 396, 728 (noting U.S. Attorneys may refuse to prosecute medicaid fraud due to backlog, insufficient expertise, or small sums involved).

208. 42 U.S.C. $\& 1320 \mathrm{a}-7 \mathrm{a}$ (1988). Before the Act was passed, the government could either initiate criminal prosecutions or sue for restitution of overpayment. See Kusserow, supra note 176, at 989.

209. 15 U.S.C. \$78u-1 (1988); see also supra note 13. 
the SEC needed a greater range of enforcement sanctions at its disposal. ${ }^{210}$ Congress could have chosen additional criminal penalties, but instead decided to increase punitive civil sanctions.

Congress also expanded civil penalties in the False Claims Act. ${ }^{211}$ The original False Claims Act, enacted in 1863, authorized the Attorney General to initiate suit in federal district court, but not to assess penalties through administrative procedures. The limitation to judicial proceedings remained in place until 1986, when the False Claims Act was amended to authorize administrative agencies to assess false claims penalties roughly equivalent to those that the Attorney General could seek in judicial proceedings. ${ }^{212}$

In voting to secure these and other statutory changes, ${ }^{213}$ Congress acted in the belief that a large portion of the fraud detected escaped sanction because existing institutional structures were inadequate to respond to them. The federal criminal system was already overloaded with complex and serious cases, and expanding its capacity would have entailed heavy costs. The hybrid administrative penalty opened the way for more cost-efficient and streamlined methods for punishing criminals. It expanded the availability of sanctions for false claims and several other regulatory offenses, thereby increasing the deterrent powers of government agencies without enlarging the field of criminal law. This change reflected a growing belief that administrative agencies need direct enforcement

210. The House Report stated:

The principal, and often effectively only, remedy available to the Commission against insider trading is an injunction against further violations of the securities laws and disgorgement of illicit profits. ... [These] serve[] only a remedial function and [do] not penalize a defendant for the illegal conduct .... The Committee believes the new penalty provided by the legislation will serve as a powerful deterrent to insider trading abuses.

H.R. REP. NO. 355, 98th Cong., 2d Sess. 7 (1984), reprinted in 1984 U.S.C.C.A.N. 2274, 2281.

211. 31 U.S.C. $\$ 3729$ (1988).

212. See supra note 192. The Senate Report to the False Claims Amendment of 1986 emphasized the difficulty in uncovering fraud against the government. S. REP. No. 345, supra note 191 , at $1-4$, reprinted in 1986 U.S.C.C.A.N. at 5266-69. Thus, in addition to the increase in judicial penalties and the creation of administrative penalties, the amendment provided for the protection of whistleblowers, 31 U.S.C. $\$ 3730$ (1988), and raised the incentive provided by the qui tam action, 31 U.S.C. $\$ 3730(d)$ (1988).

213. Another example is the Financial Institutions Reform, Recovery, and Enforcement Act of 1989, Pub. L. No. 101-73, 103 Stat. 183 (codified as amended in scattered sections of 12 U.S.C.), which follows the pattern of RICO by converting criminal offenses into civil offenses, without changing the substantive definition of the law. Congress specified that it expects civil procedure to apply to the court proceedings, 12 U.S.C.A. $\$ 1833 \mathrm{a}(\mathrm{f})(2)$ (West 1989), including the preponderance of the evidence standard. 12 U.S.C.A. $\$ 1833 \mathrm{a}(\mathrm{e})$. The House Report leaves little doubt that Congress wanted tougher sanctions because of the widespread fraud in the industry. "Regulators estimate that as many as $40 \%$ of thrift failures are due to some form of fraud or insider abuse." H.R. REP. No. 54(T), 101st Cong., 1st Sess. 300 (1989), reprinted in 1989 U.S.C.C.A.N. 96. Congress also increased the maximum criminal penalties for theft, embezzlement, or misapplication by a bank officer or employee from 5 years in prison and a $\$ 5000$ fine to 20 years in prison and a \$1,000,000 fine. 18 U.S.C. \$ 656 (Supp. I 1991); see also supra note 22.

In the Securities Enforcement Remedies and Penny Stock Reform Act of 1990, Pub. L. No. 101-429, 104 Stat. 931 (codified at 15 U.S.C.A. $\$ \$ 77$ to $80 \mathrm{~b}-14$ (West Supp. 1991)), Congress vastly expanded the civil penalty power of the SEC, saying that the "authority to seek or impose substantial money penalties, in addition to the disgorgement of profits, is necessary for the deterrence of securities law violations that otherwise may provide great financial retums to the violator." H.R. REP. No. 616, 101st Cong., 2d Sess. 17 (1990), reprinted in 1990 U.S.C.C.A.N. 1379, 1384. 
powers that are similar but not identical to criminal prosecution. ${ }^{214}$ Congress gave "prosecutorial" powers to administrative agencies without making these agencies part of the criminal process. ${ }^{215}$ Equally important, lawmakers seem to have thought of the criminal process as somehow inappropriate for "less serious" cases. Most wrongdoers charged with white-collar offenses, it was thought, could be sanctioned effectively by a "civil" process, even though their actions amounted to statutorily defined crimes.

It is important to note that agency powers typically evolved in two stages: an initial grant of authority to seek civil penalties in court was followed, sometimes many years later, by a further grant of power to assess penalties in an administrative process. ${ }^{216}$ These two settings have quite different implications for the parties involved. The court setting is more expensive, increases the procedural burden on the state, and provides the defendant with procedural rights not generally available in administrative settings. When larger sums are involved, Congress is more likely to require judicial involvement in the assessment of penalties. ${ }^{217}$ But the expansion of the administrative state has provided a framework in which to impose punitive sanctions with even greater efficiency.

The evolution from judicial to administrative assessment is partly explained by changes in the due process requirements surrounding punitive awards. At the turn of the century, when the modern administrative agency became common, due process requirements in administrative hearings were slim. As procedural safeguards penetrated administrative law in the 1960's and 1970's, the idea of giving administrative agencies stronger punitive powers became more acceptable. Still, the congressional choice of administrative setting reflected Congress' willingness to accept less formal process in decisions to impose penalties, as well as its belief that this development was judicially accepted. ${ }^{218}$

214. See Ronald A. CaSS \& COLIN S. DIVER, ADMINISTRATIVE LaW 503 (1987) ("In one sense, enforcement is what government is principally about."); $c f$. Jonathan D. Libber, Penalty Assessment at the Environmental Protection Agency: A View From Inside, 35 S.D. L. REV. 189 (1990) (explaining specific and general deterrence objectives of EPA enforcement program's reliance upon concealed civil penalty assessments).

215. See CASS \& DIVER, supra note 214, at 536-38 (suggesting problems with "prosecutorial" discretion granted to agencies).

216. See Diver, supra note 175 , at 1440 ("Most early civil money penalty statutes limited the agency's function to that of prosecuting - or more accurately, to referring cases for prosecution by the Department of Justice. . . . A few older statutes, and a number of more recent ones, contemplate a larger agency role.").

217. The evolution from judicial to administrative assessment of civil penalties is found in the False Claims Act, 31 U.S.C. $\$ 3729$ (1988), and in the Securities Enforcement Remedies and Penny Stock Reform Act of 1990, 15 U.S.C.A. $\S \S 77$ to 80 b-14 (West Supp. 1991), under which the SEC received broad administrative assessment power for the first time, adding to its only recently obtained authority to move for judicial action. In both instances the amount of the judicial penalty is larger.

218. See Ronald M. Levin, Understanding Unreviewability in Administrative Law, 74 MINN. L. REV. 689 (1990) (noting intellectual climate more favorable in recent years to complete nonreviewability of administrative action); cf. Colin S. Diver, The Optimal Precision of Administrative Rules, 93 YALE L.J. 65, 77-78 (1983) (comparing congruence standard for statutory sanctions and liability rules). 
D. Procedural Obstacles in the Criminal Process: The False Claims Act as an Example

When punitive civil sanctions were proposed in Congress, they were considered an alternative to criminal prosecution. Lawmakers thought criminal law was overly complex, oversensitive to political influence, and inefficient-an obstacle to effective law enforcement. The history of the False Claims Act, which was at the center of the case law in middleground jurisprudence, ${ }^{219}$ exemplifies particularly well the manner by which the perceived procedural inadequacies of the criminal law contributed to the development of punitive civil sanctions.

\section{The Decision to Indict and the Burden of Proof}

Congress enacted the statutory civil penalty for false claims in the wake of what it believed to have been widespread fraud against the Union Army during the Civil War. Senator Howard made clear his motivation for introducing the 1863 bill:

The country, as we know, has been full of complaints respecting the frauds and corruptions practiced in obtaining pay from the Government during the present war .... I am satisfied that more stringent provisions are required for the purpose of punishing and preventing these frauds; and with a view to apply a more speedy and vigorous remedy in cases of this kind the present bill has been prepared. ${ }^{220}$

Although federal criminal sanctions for fraud were already in place, some Senators considered the criminal process slow, biased, possibly corrupt, and otherwise ill-suited to prevent fraud. There is little doubt that the bill's sponsors believed existing criminal procedures had proved inadequate to deal with fraud on their own. As Senator Howard stated on the floor of the Senate:

[W]e all know, who are lawyers, and the most of us on this floor are such, that if we refer all these cases to the ordinary courts, and require a proceeding to be taken by a grand jury, and then a trial by a traverse jury, very little good can result. There are always persons haunting the room in which a grand jury sits with a view to influence their opinions or their findings .... I believe that in matters of this kind a grand jury is little better than useless; that instead of being a protection to the Government, who is the real sufferer in all cases, they are but a protection to the knave and the rogue. I desire to see some provision adopted

219. See supra Part II.B.3.b.

220. Cong. Globe, 37th Cong., 3d Sess. 952 (1863). 
which shall bring these gentry to speedy and exemplary justice; and I think this bill will do it. ${ }^{221}$

The view of the criminal process as ineffective was even more apparent in the words of Senator Cowan, who complained that "it is not now so much for the want of law that this mischief prevails everywhere, as it is from a seeming utter unwillingness on the part of those in authority to vindicate the laws that already exist by subjecting to punishment those who are guilty."222

We do not have sufficient empirical evidence to determine why the criminal process was perceived as ineffective. Whatever the reasons, however, Congress sought a more streamlined and more effective punitive sanction that could be used without triggering criminal procedure. The new law fundamentally changed the sanctioning of false claims. In order to encourage disclosure of information, the legislation provided for qui tam actions, in which a private person could bring suit on the government's behalf and share in the penalty proceeds. $^{223}$ The statute dispensed with the troublesome grand jury and avoided requiring proof of liability beyond a reasonable doubt. The government's choices were no longer limited to a criminal action combined with a compensatory civil action for fraud or breach of contract; the 1863 legislation gave the government the additional option of seeking punitive money sanctions in a noncriminal proceeding. ${ }^{224}$ This change was intended to have two important effects. First, sanctions could be imposed on many persons against whom the government would not otherwise have proceeded. Second, the new civil penalty could be used against persons whom the government would otherwise have indicted, reserving the criminal sanction for truly heinous cases. The combination of sanctioning more people and reducing the use of the criminal sanction enlarged the middleground.

\section{Access to Evidence}

A central concern of any sanctioning system, as I indicated in describing the paradigms, is access to information. ${ }^{225}$ Information-or evidence-is a necessary ingredient in any decision to mete out sanctions. The conventional procedural characteristics of civil and criminal law created different kinds of barriers to the collection and presentation of information with concomitant

221. Id. at 955 .

222. Id. at 954 .

223. Id. at 953 .

224. As stated in $\S 4$ of the bill, a person who committed any of the prohibited acts "shall forfeit and pay to the United States the sum of $\$ 2,000$, and, in addition, double the amount of damages which the United States may have sustained by reason of the doing or committing [of] such act, together with the costs of suit." Id. at 953 .

225. See supra Part I.D.1. 
advantages and disadvantages. But reforms in procedure increased the attractiveness of the civil process.

\section{a. Civil Procedure in the Courts}

By creating a punitive civil sanction, the False Claims Act of 1863 removed a large class of cases seeking punitive sanctions from the realm of the grand jury, the formal rules of a criminal indictment, the burden of proof beyond a reasonable doubt, and the strict evidentiary rules applicable in a criminal trial. Had the pre-twentieth century civil rules of pretrial procedure remained in place, however, the absence of effective pretrial discovery techniques in civil cases would have substantially offset these advantages to the government. ${ }^{226}$ In the nineteenth century, criminal procedure provided a wide array of investigatory devices, while civil procedure had almost none at its disposal. James and Hazard summarized the status of civil procedure during this period in a critical note: "What the nineteenth century reformers failed to see was that the old equity restrictions on discovery (which were a natural corollary of its original limited purpose) would hamstring its usefulness as a means for attaining the new and broader purposes which were beginning to be perceived."227

Sweeping reforms in the twentieth-century made the civil setting for punitive sanctions even more attractive to the government than it had been in 1863 . A series of new devices permitted each party in a civil suit to discover all facts relevant to the dispute before trial. ${ }^{228}$ In Hickman v. Taylor, ${ }^{229}$ the Supreme

226. The criminal process could not be used to discover evidence in a patently civil case and vice versa. In tax fraud investigations prior to 1982 , for instance, it was widely believed that under 21 U.S.C. $\$ 7602$, a civil summons could not be used to collect information for criminal prosecution. But see United States v. LaSalle Nat'l Bank, 437 U.S. 298 (1978) (IRS not prohibited from using civil summons to gather evidence solely for criminal investigation as long as summons was not issued in bad faith). As amended in 1982, that section now permits the use of civil process to investigate an offense so long as the case has not been referred to the Department of Justice. 21 U.S.C. $\$ 7602$ (1988).

227. Fleming James, JR. \& Geoffrey C. HAZARD, JR., Civil PROCEDURE 227 (3d ed. 1985). At the turn of the century, civil procedure was cumbersome, formalistic, and often difficult to use. This was particularly true of the procedural devices used for discovering information from adversaries. With few exceptions, parties to civil proceedings (including the govemment) were left to their own devices to persuade opposing parties and witnesses to cooperate before trial by providing documents or by making pretrial statements. It was more likely that parties simply would have to wait until trial to learn of their opponent's evidence. This procedural arrangement made a civil suit risky and often unattractive. See generally id. at 223-30; ROBERT W. MILLAR, CIVIL PROCEDURE OF THE TRIAL COURT IN HISTORICAL PERSPECTIVE 204-08 (1952); GEORGE RAGLAND, JR., DISCOVERY BEFORE TRIAL (1932); Jack B. Weinstein et al., Procedures for Obtaining Information Before Trial, 35 TEX. L. REV. 481 (1957).

228. The most important change appeared first in the New York Civil Practice Law and Rules, which made oral deposition of parties a regular procedure. See MILLAR, supra note 227, at 206. The broadening of discovery in the states was adopted and expanded in the even more "liberal" federal rules of civil discovery. Millar reported that the new rules of pretrial discovery in civil cases provided for any party to take the testimony of any person, party or nonparty, "'by deposition upon oral examination or written interrogatories for the purpose of discovery or for use as evidence in the action or for both purposes." Id. at 213 (quoting then-existing FED. R. CIV.P. 26(0)). The power to obtain information in pretrial proceedings in civil cases was extended to apply to any person with relevant knowledge and to any relevant facts, even if they could not be introduced in evidence. See FED. R. CIV. P. 26(b)(1).

229. 329 U.S. 495 (1947). 
Court emphasized the extent of this core change in the principles governing civil litigation:

Under the prior federal practice ... [i]nquiry into the issues and the facts before trial was narrowly confined and was often cumbersome in method. ... . [Under the new rules] civil trials in the federal courts no longer need be carried on in the dark. The way is now clear, consistent with recognized privileges, for the parties to obtain the fullest possible knowledge of the issues and facts before trial. ${ }^{230}$

The discovery reforms broadened the scope of available evidence, helped prevent fraud, and encouraged pretrial settlement. ${ }^{231}$ Even while limiting access to the work product of attorneys, the Hickman Court echoed this view:

No longer can the time-honored cry of "fishing expedition" serve to preclude a party from inquiring into the facts underlying his opponent's case. Mutual knowledge of all the relevant facts gathered by both parties is essential to proper litigation. To that end, either party may compel the other to disgorge whatever facts he has in his possession. $^{232}$

One of the central assumptions underlying these changes was the view that increased access to information in civil discovery facilitated a more comprehensive enforcement of rights. ${ }^{233}$ This belief touched directly on the relationship between procedure and the aims of sanctioning systems: if open discovery brought more facts about a case into the adjudicative forum, it would focus the sanctions of the system on "wrongful behavior" and would pass over innocent behavior. $^{234}$

The government's discovery powers in administrative procedures also changed fundamentally in the twentieth century. Administrative powers to

230. Id. at 500-01 (citations omitted).

231. Developments in the Law-Discovery, 74 HARV. L. REV. 940, 944-46 (1961).

232. Hickman, 329 U.S. at 507 (citation omitted).

233. "[Open discovery] makes possible the prosecution of actions (and sometimes the defense of actions) that would be impossible without discovery. With wide-ranging discovery, it is possible to maintain an action or defense that is dependent on witnesses or documents known only to the opponent ...." JAMES \& HAZARD, supra note 227, at 229. But see Judith Resnik, Failing Faith: Adjudicatory Procedure in Decline, 53 U. CHI. L. REV. 494, 520-24 \& n.117 (1986) (inequality in resources to use discovery tools makes adjudications asymmetric).

234. More recently, discovery in criminal cases has become broader, moving away from the rule of strict limitation. For accounts of the restrictive past of criminal discovery and the slow erosion of barriers, see generally WAYNE R. LAFAVE \& JEROLD H. ISRAEL, CRIMINAL PROCEDURE §§ 19.3-.4 (1985); William J. Brennan, Jr., The Criminal Prosecution: Sporting Event or Quest for Truth?, 1963 WASH. U. L.Q. 279, 292; Barry Nakell, Criminal Discovery for the Defense and the Prosecution-The Developing Constitutional Considerations, 50 N.C. L. REV. 437, 438 (1972) (contrasting civil and criminal procedure, citing modem trend to broaden defense discovery of prosecutorial evidence and information sources); Monrad G. Paulsen, Criminal Law Administration: The Zero Hour was Coming, 53 CAL. L. REV. 103, 118 (1965); Roger J. Traynor, Ground Lost and Found in Criminal Discovery, 39 N.Y.U. L. REV. 228 (1964) (citing congressional cutback of discovery and recommending its expansion). 
compel production of evidence had been narrowly defined during the early part of the century. As the Court observed in United States v. Morton Salt Co., "sometimes, especially early in the history of the federal administrative tribunal, the courts were persuaded to engraft judicial limitations upon the administrative process. The courts could not go fishing, and so it followed neither could anyone else. Administrative investigations fell before the colorful and nostalgic slogan 'no fishing expeditions."'235

Morton Salt, a landmark case testing the authority of the Federal Trade Commission to compel the production of documents, points to two aspects of the development of administrative agencies' investigatory powers. First, such powers are relatively new; only since the 1930's have administrative agencies had the power and the personnel to offer an alternative to criminal investigations. Second, courts initially interpreted the agencies' new powers narrowly and restricted agency authority to compel the production of information in investigative proceedings. In Morton Salt, however, the Court set a new tone by providing an expansive interpretation of administrative powers:
Because judicial power is reluctant if not unable to summon evidence until it is shown to be relevant to issues in litigation, it does not follow that an administrative agency charged with seeing that the laws are enforced may not have and exercise powers of original inquiry. It has a power of inquisition, if one chooses to call it that, which is not derived from the judicial function. . . . When investigative and accusa- tory duties are delegated by statute to an administrative body, it, too, may take steps to inform itself as to whether there is probable violation of the law..$^{236}$

Building on a reformed administrative procedure, ${ }^{237}$ another important new development was the grant to the Attorney General of authority to issue the "civil investigative demand" (CID) ${ }^{238}$ For many years the Civil Division of the Department of Justice had no authority to subpoena documents. Therefore, its attorneys often had to wait for the relevant administrative agency to act. In the 1950's, this procedure impeded the enforcement of the antitrust laws because of the restricted powers of the Federal Trade Commission. To tackle this problem, Congress considered a reform bill in 1961. The House Report criticized "ineffective" techniques for obtaining information necessary for civil

235. United States v. Morton Salt Co., 338 U.S. 632, 642 (1950).

236. Id. at $642-43$.

237. Petition of Gold Bond Stamp Co., 221 F. Supp. 391, 395-96 (D. Minn. 1963), aff'd, 325 F.2d 1018 (8th Cir. 1964); see also Anthony J. McFarland, Note, The Civil Investigative Demand: A Constitutional Analysis and Modest Proposal, 33 VAND. L. REV. 1451 (1980) (following Court's decisions in Morton Salt and Oklahoma Press Publishing Co. v. Walling, Wage \& Hour Admin., 327 U.S. 186 (1946), modem law of administrative investigation developed rapidly, and agencies received extensive powers to demand information).

238. See McFarland, supra note 237; Richard L. Perry \& William Simon, The Civil Investigative Demand: New Fact-finding Powers for the Antitrust Division, 58 MICH. L. REv. 855 (1960). 
enforcement ${ }^{239}$ and stated that "to enforce the antitrust laws adequately on the civil side, the antitrust authorities must be able to make an adequate investigation to ascertain the facts. ${ }^{2240}$ When passed in 1962, the bill gave the Civil Division authority in antitrust investigations to issue written civil investigative demands for documents, enforceable by district courts. ${ }^{241}$ The legislation thus significantly strengthened the Justice Department's powers to obtain access to information in civil antitrust enforcement proceedings. ${ }^{242}$ The $\mathrm{CID}$ became a model for other agencies that sought similar powers. ${ }^{243}$ The growing arsenal available to the government in civil investigations provides the government with access to information at an earlier stage in the sanctioning process.

\section{b. Extending Procedural Reform: The False Claims Act}

Congress' 1986 amendment of the False Claims Act echoed the concerns of an earlier period. Congress believed the criminal justice system was inadequate for sanctioning suspected fraud on the government because investigative and prosecutorial resources were limited and because criminal procedure's evidentiary and due process requirements made it difficult to secure criminal convictions. Therefore, Congress concluded that civil sanctions needed to be

239. Those techniques included the required cooperation of the target of the investigation, which the report found unsatisfactory because "it leaves the public interest in the enforcement of the antitrust laws subject to the will of those who violate the laws"; investigation through use of a grand jury subpoena, which the report found unsatisfactory because it is "an abuse of process to proceed by way of a grand jury investigation where there is no intention to bring a criminal suit"; and the Attorney General's statutory power to request that the FTC conduct an investigation, which the report found unsatisfactory because of the uncertainty as to "whether the Commission is under an obligation to make such investigations," and "because of the inability of the Department's attorneys to maintain control of such investigation." H.R. REP. NO. 1386, 87th Cong., 2d Sess. 3-4 (1962), reprinted in 1962 U.S.C.C.A.N. 2567, 2568-69.

240. Id. at 3, reprinted in 1962 U.S.C.C.A.N. at 2568.

241. Pub. L. No. 87-664, § 3, 76 Stat. 548 (codified at 15 U.S.C. $\S 1312$ (1962)). At the time of enactment, at least 17 states had similar laws. See Gold Bond Stamp Co., 221 F. Supp. at 394.

242. In an important expansion of that power, the statute was amended in 1980 to allow the Department of Justice to issue demands for information already obtained by a private litigant through civil discovery. Pub. L. No. 96-349, § 2(b)(1)-(3), 94 Stat. 1154 (1980) (codified at 15 U.S.C. § 1312 (1988)). The House Report commented: "To preclude access to discovery materials already assembled and analyzed in another proceeding is wasteful, and in some cases, tantamount to denying access altogether. . . . More importantly, the expense of reassembling pre-existing materials and repeating the indexing and analyzing procedures can be very substantial, particularly in the case of large scale antitrust investigations." H.R. REP. No. 870, 96th Cong., 2d Sess. 6 (1980), reprinted in 1980 U.S.C.C.A.N. 2716, 2719-20. The report recounted the government's successful attempt to obtain 400,000 documents from the GAF corporation relating to its antitrust claim against Kodak, which provided the government with information that it probably could never have assembled on its own. Id. at 6, reprinted in 1980 U.S.C.C.A.N. at 2720.

243. The 1986 amendment to the False Claims Act gave the Attomey General the power to compel production of information in all investigations of false claims on the government. Congress employed the antitrust $\mathrm{CID}$ as the model, thereby greatly increasing the scope of the Department of Justice's civil information collection powers. 31 U.S.C. $\$ 3733$ (1988). 
used more frequently and that civil investigative procedures required strengthening. ${ }^{244}$

As part of the 1986 reform, Congress sought to increase incentives for private citizens to expose wrongdoing. In its statement to Congress, the Civil Division detailed notable qui tam cases that had been instituted with special insider information about wrongs committed against the government. ${ }^{245}$ The 1986 amendment sought to encourage more of such activity; it increased the amount of money that a successful qui tam plaintiff could receive by guaranteeing her a percentage of the award. The amendments also allowed the qui tam plaintiff to take a more active role in her suit by requiring that she be informed of the suit's progress and by permitting her to take over the suit if the government had not proceeded in a timely manner. ${ }^{246}$ As a further incentive for disclosing fraud, Congress provided "whistleblower protection" to "make whole" any employee "demoted, suspended, threatened, harassed, or in any other manner discriminated against" for exposing fraud. ${ }^{247}$ Congress also made sweeping increases in the government's access to evidence in the civil forum, broadening administrative agencies' powers to investigate false claims cases. As enacted, the amendment empowered the Attorney General to issue CID's, including demands for oral testimony, but denied this power to other investigative officers. ${ }^{248}$

The probability that wrongdoing will be sanctioned depends not only on the obstacles to information gathering, but also on the evidentiary burden that the party seeking sanctions must meet. That, in turn, is a function of two factors: the definition of the elements of the offense and the burden of proof

244. S. REP. No. 345, supra note 191, at 4, reprinted in 1986 U.S.C.C.A.N. at 5269. The Senate report on the False Claims Amendments Act stated: "It appears there are serious roadblocks to obtaining information as well as weaknesses in both investigative and litigative tools." Id.

245. Id. at 14, reprinted in 1986 U.S.C.C.A.N. at 5279.

246. Prior law did not guarantee the relator (the person bringing the qui tam action) a percentage take from a successful lawsuit. The False Claims Amendments Act "acknowledges the risks and sacrifices of the private relator and sets a minimum ... level of recovery," id. at 28 , reprinted in 1986 U.S.C.C.A.N. at 5293 (discussing 31 U.S.C. $\$ 3730$ (d)(1) (1988)), and also allows for attomeys' fees. The courts retain discretion to set the recovery above the minimum depending on the significance of the information provided by the private plaintiff. Id. at 30, reprinted in 1986 U.S.C.C.A.N. at 5295. In addition, where the government takes over the claim, the amended Act requires that the private party be informed of all steps taken by the government, and grants the private party a formal right to object to a dismissal or proposed settlement. 31 U.S.C. $\$ 3730(\mathrm{c})(2)(\mathrm{A})$-(B). Thus, the proposed bill was meant to provide "qui tam plaintiffs with a more direct role not only in keeping abreast of the Government's efforts and protecting his [sic] financial stake, but also in acting as a check that the Government does not neglect evidence, cause unduly [sic] delay, or drop the false claims case without legitimate reason." S. REP. No. 345, supra note 191, at 25-26, reprinted in 1986 U.S.C.C.A.N. at 5290-91.

247. The Senate Report offered evidence of the need for this kind of protection: [One witness, a defense contractor employee,] said he has concluded not only from his own experience but from talking to his fellow workers that there is "absolutely no encouragement or incentive" for individuals working in the defense industry to report fraud. Instead, he said, there is a great disincentive due to employer harassment and retaliation. ". . . [M]ost individuals just simply cannot and will not put their head on the chopping block."

S. REP. NO. 345, supra note 191, at 5, reprinted in 1986 U.S.C.C.A.N. at 5270.

248. 31 U.S.C. \& 3733(a)(1) (1988). 
required to establish each element. Before the False Claims Amendments Act, courts had divided over whether the party seeking sanctions in a civil false claims action had to prove that the defendant had actual knowledge of falsity, or whether proof of grossly negligent inattention to the truth sufficed. ${ }^{249}$ The difference between the two standards is formally a matter of the substantive definition of the offense; the negligence standard imposes sanctions on a broader range of behavior. However, because evidence that proves actual knowledge is more difficult to obtain than evidence that proves negligence or gross negligence, a negligence standard reduces the moving party's burdens of evidence gathering and proof. In other words, the negligence standard not only allows the imposition of sanctions on persons who lacked actual knowledge, ${ }^{250}$ but also permits the imposition of sanctions on persons whose actual knowledge cannot be proven with the information available to law enforcement authorities. By adopting a negligence standard, the 1986 amendments eliminated the ambiguities created by lower court opinions.

Congress also dealt with the second aspect of the evidentiary burden: the formal burden of proof. Because the criminal standard of proof requires a high degree of certainty, prosecutors often decide not to seek criminal penalties even when convinced of their target's guilt. Similarly, the "clear and convincing evidence" standard, which lies somewhere between the regular civil standard and the criminal standard, might stop a law enforcement official from seeking penalties. The amendment adopted the conventional civil standard, a preponderance of the evidence, thereby facilitating further the sanctioning process. ${ }^{251}$

This interpretation contradicted the original intent of the Congress that enacted the first False Claims Act, and these reforms were contingent on the revised False Claims Act passing constitutional muster. Although Congress understood very well that it was instituting new "punitive" sanctions, ${ }^{252}$ the word "punitive" was conspicuously absent from the 1986 debate. Congress' suspicion that the new treble damages penalty, which came to replace the double damages penalty, might lead courts to apply criminal procedure to false claims cases seemed unwarranted in light of existing jurisprudence on similar damage provisions in the antitrust context. Nonetheless, it indicated that members of Congress and Justice Department lawyers did not perceive a clear boundary between criminal and civil sanctions. It also demonstrated that the norms of the civil and criminal paradigms dominated the thinking of lawmakers and that the middleground created disturbing ambiguities for some of them.

249. S. REP. No. 345, supra note 191, at 6-7, reprinted in 1986 U.S.C.C.A.N. at 5271-72.

250. Id. at 7, reprinted in 1986 U.S.C.C.A.N. at 5272 (explaining negligence standard as way to "hold responsible those corporate officers who insulate themselves from knowledge of false claims").

251. In adopting this standard, Congress resolved a split in the case law by selecting the view held by the majority of courts. See id. at 31, reprinted in 1986 U.S.C.C.A.N. at 5296.

252. See supra text accompanying notes 213-15. 
As the reform of the False Claims Act suggests, the broad changes in administrative procedure, civil judicial procedure, and civil investigatory power were intended to make the civil sanctioning process better able to unearth information necessary for the successful imposition of sanctions. As a result, the civil process now attracts cases previously handled in the criminal paradigm. Although the criminal setting requires the government to prove guilt beyond a reasonable doubt, this burden is offset (at least in part) by the vastly superior information gathering ability provided by the powers of search and seizure, custodial interrogation, and the grand jury subpoena. While criminal investigatory procedures are superior in a focused investigation, the reforms in civil and administrative procedure reduced the differences between the criminal and civil settings, making the punitive civil suit-whether in a courtroom or in an administrative forum-a compelling alternative to criminal prosecution.

\section{Implications of the GROWING Role of Punitive CiviL SANCTIONS}

The vast growth in punitive civil sanctions has broad implications for future legal sanctioning. A society in which many offenders can be made to pay severe civil penalties has compelling reasons to shrink the criminal law. A newly conceptualized three-paradigm jurisprudence of sanctioning-composed of criminal, punitive, and remedial sanctions - would reserve criminal law for a much smaller proportion of all sanctionable offenses. As the most extreme form of the state's punitive power, the criminal law would be invoked only when necessary to maintain a public threat of severe punishment for those who cause the most harm in the most blameworthy circumstances.

Under the new tripartite structure, the growth of punitive civil sanctions would result in more sanctioning, and consequently more social control, than would occur under a legal regime in which the government could only choose between criminal and compensatory civil sanctions. Under the traditional paradigmatic structure, a broad range of offenses goes entirely unsanctioned. Potential targets of enforcement probably perceive this result as an expression of society's jealousy of freedom of action. In the tripartite structure, therefore, the rise of punitive civil sanctions may bring with it the specter of increasing governmental intrusion into private and corporate life for the purpose of greater social control; while the change in sanctioning capacity has an Orwellian hue, the actual consequences of these developments will depend on how the implementation of these sanctions is checked and controlled.

This Article advocates an expansion in the size and availability of punitive civil monetary sanctions. The jurisprudence of the past suppressed growth in civil monetary sanctions because courts persisted in the fiction of calling them forms of compensation, deterrence, or debt collection, apparently to avoid using procedures drawn from the criminal paradigm. Now that these sanctions have been called punitive and have nonetheless survived constitutional challenge, we 
have an important opportunity to create a new regime of punitive sanctions. A new paradigm can be established in the middleground between civil and criminal law. This new approach would levy punitive monetary sanctions (but not as punitive as criminal sanctions) in response to behavior that is culpable (but not egregious enough to require criminal sanctions). Severely punitive monetary sanctions would require especially stringent procedures (but not as stringent as criminal procedures).

These changes would reflect the appropriate position of the criminal law in an era in which specialized agencies wield growing prosecutorial responsibilities. As punitive civil sanctions are used with greater frequency to punish and deter wrongdoers, criminal law should become more of a residual sanction. It should continue to reinforce social solidarity around basic values, but routine sanctioning should be achieved through state-invoked punitive civil sanctions, which are capable of a broader reach because of their less serious implications and their less burdensome procedural setting. ${ }^{253}$

\section{A. Administrative Agency Prosecution}

The grant of broad punitive powers to administrative agencies has caused most of the state's punitive sanctioning to occur in the context of civil proceedings. ${ }^{254}$ But the principal mission of administrative agencies-the regulation of specialized areas of economic and social life-does not require such a grant of power. Administrative agencies have long possessed a wide range of tools: the power to dispense money, to set standards, to bring civil suits seeking cease-and-desist orders or injunctions, to initiate contempt proceedings for violations of such orders or injunctions, to issue licenses, and to order compensation awards, forfeiture, disqualification, and, of course, money penalties. ${ }^{255}$ Although each of these sanctions can serve punitive purposes, ${ }^{256}$ all but money penalties can also function in a nonpunitive manner. For example, agencies spend money to influence action; they set standards to provide measures of minimally acceptable conduct; they issue injunctions to prevent wrongful conduct; they withhold licenses to exclude unreliable persons from positions of public responsibility; and they forfeit contraband to exclude harmful items from public access.

In assessing the powers of administrative agencies and the role of punishment in regulations, we should recognize that it is possible to confine all

253. See SUSAN ShaPIRO, WAYWARD CAPITALISTS 159 (1984) (reporting limited use of criminal sanction in securities fraud investigations).

254. See Susan Shapiro, The Road Not Taken: The Elusive Path to Criminal Prosecution for White-Collar Offenders, 19 LAW \& SOC. REV. 179, 187-90 (1985) (SEC uses civil and administrative sanctions more often than criminal sanctions).

255. BREYER \& STEWART, supra note 200, at 3-6.

256. Although agencies generally do not punish via their power to spend money, they may do so, for example, by withholding future payments or contracts from violators. 
punitive power to the office of the criminal prosecutor, which could also be authorized to seek punitive civil penalties as an alternative to criminal penalties; such an approach would be consistent with applying those procedural requirements that proponents of the middleground have sought to avoid. But the movement toward punitive civil sanctions has taken a different direction, transforming not only the law but also the administrative agency, and, at a larger level, the organization of law enforcement. It is no longer correct to say that administrative agencies only regulate action; administrative agencies also prosecute. $^{257}$ The multiplication of administrative agencies has further decentralized the power to punish.

\section{B. The Attenuated Role of Criminal Prosecution}

The growth of punitive civil sanctions directly affects criminal law. It lessens the need to use the criminal law to sanction wrongs and permits a more flexible response to wrongful conduct. Legislatures can authorize new civil penalties rather than develop criminal sanctions, and enforcement agencies can impose the new punitive civil sanctions, saving litigation costs and avoiding unnecessarily harsh criminal punishment. ${ }^{258}$ While the reach of the criminal law has expanded consistently, the availability of punitive civil sanctions has avoided some of the inflation of criminal laws that would otherwise have occurred. In the future, reliance on the criminal law to achieve punitive purposes should be reduced, and increases in the number and size of available civil penalties, the number of agencies that can impose them, and the range of conduct to which they apply should be encouraged.

Criminal law has a distinctive normative role, and it should be reserved for the most damaging wrongs and the most culpable defendants. Middleground jurisprudence presents a special opportunity for reform, permitting the criminal law to be scaled back where it has been overextended-with respect to petty and middle-range crimes, regulatory and administrative offenses, and some of the so-called victimless crimes where the use of criminal sanctions has long been controversial. ${ }^{259}$ Punitive civil penalties can both increase sanctioning power and reduce reliance on criminal law for a range of intermediate offenses, particularly those committed by the middle class in the course of their occupations.

257. Even where the statute requires a court proceeding rather than an administrative hearing, it is the agency's attomeys who decide whether to bring the civil suit and then prosecute the action.

258. Notwithstanding the criminalization of many activities, courts and prosecutors have begun to rely more heavily on civil penalties when seeking to enforce the law.

259. See John C. Jeffries, Jr. \& Paul B. Stephan III, Defenses, Presumptions, and Burden of Proof in the Criminal Law, 88 YALE L.J. 1325, 1367 (1979) (Supreme Court has eschewed defining substantive limits of criminal law, quoting Henry Hart: "What sense does it make to insist upon procedural safeguards in criminal prosecutions if anything whatever can be made a crime in the first place?"). See generally Ann Hopkins, Mens Rea and the Right to Trial by Jury, 76 CAL. L. REV. 391 (1988) (suggesting that moral culpability is prerequisite for jury verdicts in criminal cases, limiting substantive scope of criminal law). 


\section{Relationship Among Criminal, Punitive Civil, and Remedial Sanctions}

The recognition of a new paradigm requires an analysis and appreciation of the interrelationship of the various sanctions, and calls for a refined jurisprudence of their substantive scope, their severity, and the procedures for their imposition.

\section{Substantive Scope}

In a tripartite structure of paradigms, criminal, punitive civil, and remedial sanctions co-exist. Punishment is meted out in the first two categories; the third category includes both compensatory sanctions and other civil sanctions whose aim is prophylactic rather than punitive. Criminal law derives its character from its relation to punitive civil sanctions and remedial sanctions, just as these other sanctions derive meaning in relation to, and as distinguished from, characteristics of the criminal law. The interrelation of these sanctions affects both their substantive scope and their respective procedural contexts.

A logical and normatively coherent system of sanctions should define each paradigm —criminal, punitive civil, and remedial-in relation to the others, with reference to both the purpose and the severity of the wrongful conduct addressed by each. Different sanctions should apply to wrongs of different magnitudes. The universe of wrongs to which punishment applies should be divided so that criminal law is applicable only to the most severe wrongs, while punitive civil sanctions are limited to other wrongs requiring punishment.

The normative structure of legal sanctions has equally important implications for the relationship between criminal and civil punitive sanctions on the one hand and remedial sanctions on the other. Because of the existence of two paradigms of punitive sanctions, a coherent jurisprudence must first distinguish between civil and criminal processes within the field of punitive sanctions. Second, it must differentiate between conduct for which punitive sanctions are fitting and conduct for which they are inappropriate. ${ }^{260}$ Limiting the scope of punitive sanctions for wrongful conduct creates a definitive substantive area of remedial sanctions that is designed to compensate an injured party or to prevent the occurrence of wrongful conduct through nonpunitive measures.

260. PACKER, supra note 18, at 251. Packer argues:

Whether the subject happens to be traffic offenses, or hunting out of season, or breaches of housing codes, or any of the thousands of minor regulatory or sumptuary offenses with which the criminal sanction and its processes are presently encumbered, we ought to purge from the criminal calendar all offenses that we do not take seriously enough to punish by real criminal sanctions.

Id. at 273. For this task he recommends the use of a "publicly instituted civil action for the recovery of a monetary penalty." Id. Thus, Packer sees the penalty suit as an appropriate sanction for minor offenses or infractions. My thesis is broader: Civil penalties can and should be used in a large range of cases involving serious violations of conduct norms. 
These distinctions properly suggest that punitive and remedial sanctions may be applied to the same conduct, the two sanctions serving different purposes.

Within this tripartite framework, legislatures, administrative agencies, and judges will have to perform a critical task. They must formulate guidelines for the seriousness of offenses that rationally allocate wrongs in the substantive areas of each paradigm, and they must systematically divide the universe of wrongs into criminal, punitive civil, and remedial categories. Broad legislative and administrative guidelines should be developed to rank the seriousness of cases for the purpose of distinguishing criminal and civil punitive sanctions. The interpretation of such guidelines give judges a central role in creating the jurisprudence of punitive sanctions.

\section{Are Punitive Civil Sanctions Desirable?}

Punitive civil sanctions have long been part of the American law of sanctions. After United States v. Halper, ${ }^{261}$ it seems likely that, in many areas of public life, government agencies will increasingly obtain independent power to use them. This Article argues that punitive civil sanctions play a central role in protecting society from both underenforcement and overenforcement of the norms that make up the social order.

The middleground prevents underenforcement by providing a punitive sanction for conduct that, within the two-paradigm structure, would be pushed into the remedial paradigm because it is not severe enough to justify a criminal sanction. The middleground also avoids overenforcement by providing a noncriminal punitive sanction for conduct that otherwise would be pushed into the criminal paradigm because its severity makes it unreasonable to impose only a remedial sanction. In this sense, the middleground allows for more proportionate punitive sanctioning. When punitive civil sanctions are available, cases otherwise confined to the conventional paradigms shift into the middleground, increasing overall sanctioning while reducing reliance on both criminal sanctions and merely remedial sanctions. ${ }^{262}$ This increased proportionality argues for expanding the use of punitive civil sanctions, but this development will not be justified until the distortion in procedural protections that has developed within middleground jurisprudence is corrected. ${ }^{263}$

261. 490 U.S. 435 (1989).

262. See Shapiro, supra note 254 , at 205 (concluding that for SEC enforcement proceedings "the presence of civil or administrative prosecutorial options has a powerful negative effect on the likelihood that enforcers will select either of the two extreme dispositions-no legal action and criminal prosecution").

263. In the early period, banking law enforcement agencies had to choose between severe criminal sanctions on the one hand and largely ineffective administrative remedies on the other. See Lawrence G. Baxter, Judicial Responses to the Recent Enforcement Activities of the Federal Banking Regulators, 59 FORDHAM L. REV. 193, 198 (1991). A major change occurred when Congress passed FIRREA. See supra note 22. 


\section{Parallel State-Invoked Punitive Sanctions}

The historic overlap of criminal and punitive civil authority stemmed not only from the advantages deriving from flexible sanctions, but also from the fact that the integrity of decisionmaking processes drew strength from the checks and balances created by the institutional interdependence of agencies and criminal prosecutors; each decisionmaker knew that another entity was making many of the same assessments. In addition, the government enjoyed extra leverage over potential defendants by being able to pursue two avenues simultaneously. In parallel enforcement proceedings, defendants risked getting one penalty "ratcheted up" if they obtained a good settlement in the other; ${ }^{264}$ to avoid this risk, defendants had to deal with both antagonists at once.

To the extent that these dynamics helped law enforcement, the Halper rule will probably make law enforcement more difficult, though fairer for potential defendants. ${ }^{265}$ Under Halper, punitive civil sanctions cannot be imposed for conduct that has already been punished by a criminal conviction. It appears that criminal punishment likewise cannot be imposed for conduct for which the government has already obtained punitive civil sanctions. ${ }^{266}$ However, the Halper Court implied that simultaneous imposition of criminal and punitive civil sanctions is valid. ${ }^{267}$ But barring a decision to seek both sanctions at the same time, law enforcement authorities must decide which sanction to choose. The old system of postponing the decision, or of pursuing both punitive sanctions at the same time without paying attention to which is imposed first, is no longer feasible. ${ }^{268}$

At a minimum, this development implies that prosecutors and administrative agencies must find new ways to coordinate their actions and establish rules binding on both concerning whom to punish and whether to use criminal or

264. Interview with Charles Stillman, defense attorney and former Assistant U.S. Attorney in New York City (Aug. 10, 1988).

265. See supra Part II.D.

266. See United States v. Sanchez-Escareno, 950 F.2d 193, 200 (5th Cir. 1991) ("[T]he Halper principle that a civil penalty can be factored into the double jeopardy matrix should apply whether the civil penalty precedes or follows the criminal proceeding."); United States v. Mayers, 897 F.2d 1126, 1127 (11th Cir. 1990) ("Although in this case the civil penalty preceded, rather than followed the criminal indictment, the Halper principle that civil penalties can sometimes constitute criminal punishment for double jeopardy purposes would seem to apply whether the civil penalties ccme before or after the criminal indictment."), cert. denied, 111 S. Ct. 178 (1990); see also United States v. Bizzell, 921 F.2d 263, 266-67 (10th Cir. 1990) (recognizing that under Halper, disproportionate civil penalty would bar subsequent criminal prosecution).

267. See Jahncke, supra note 14, at $139-42$ (by prohibiting successive, but not simultaneous, use of criminal conviction and punitive civil sanction, Supreme Court has not gone far enough to protect defendants from possible double punishment).

268. Leverage continues to exist in offering a potential defendant an opportunity to cooperate in a civil enforcement action in exchange for agreeing not to pursue criminal charges. It can be assumed that defendants prefer to be targeted only in civil investigations, and that the prospect of a criminal investigation or prosecution sometimes yields an agreement not to contest civil sanctions. 
civil sanctions. ${ }^{269}$ A key question, then, is how to unify decisionmaking between these two players in meting out punitive sanctions.

Preserving the administrative agency's role in making decisions about sanctioning is critical to the rationalization of punitive sanctions. Administrative agencies have special expertise in identifying and assessing violations. They have firsthand experience with potential offenders and with the substantive law over which they have regulatory authority. This expertise provides them with important advantages in understanding the seriousness of a particular violation. Agency specialization can therefore play a key role in distinguishing cases fit for criminal sanctions from those fit only for punitive civil sanctions, particularly when both kinds of sanctions are available.

Without a jurisprudence of severity, the choice between criminal, punitive civil, and remedial sanctions would be arbitrary. Because of their specialized advantage in making the complex distinctions about severity necessary for equal and proportionate treatment in a unified system of punitive sanctions, administrative agencies should play a significant role in shaping punitive sanctioning policy. Prosecutors should have to consult administrative agencies before bringing criminal prosecutions. ${ }^{270} \mathrm{By}$ the same token, however, administrative agencies must also consult prosecutors before imposing punitive civil sanctions, lest they foil plans for a subsequent criminal prosecution. Since the same conduct can often be punished with either criminal or civil sanctions, any solution must include joint decisionmaking. ${ }^{271}$

\section{Private Punitive Sanctions}

Punitive sanctioning in actions brought by private citizens has recently become a more important element of the entire sanctioning scheme, ${ }^{272}$ and the Supreme Court has upheld large punitive damages awards against due

269. Note that the "General Application Principles" of the Federal Sentencing Guidelines do not require judges to inquire whether civil sanctions can or will be imposed. U.S. SENTENCING COMM'N, FEDERAL SENTENCDNG GuIDELINES MANUAL § 1B1.1 (1992). Likewise, the Guidelines do not provide for changes in a defendant's score, which contributes to the determination of his sentence, based upon the imposition of civil sanctions. Id. $\$ \$ 3 \mathrm{~A}-3 \mathrm{E}$. When determining the amount of the defendant's fine, however, "the court shall consider: . . . any restitution or reparation that the defendant has made or is obligated to make; [and] any collateral consequences of conviction, including civil obligations arising from the defendant's conduct." Id. $\$ 5 \mathrm{E} 1.2(\mathrm{~d})(4)-(5)$.

270. See Joseph T. Small, Jr. \& Robert A. Burgoyne, Criminal Prosecutions Initiated by Administrative Agencies: The FDA, The Accardi Doctrine and the Requirement of Consistent Agency Treatment, $78 \mathrm{~J}$. CRM. L. \& CRIMINOLOGY 87, 116-17 (1987) (suggesting development of due process rules that make for consistent agency treatment of regulated bodies in making referrals for criminal prosecution).

271. A more far-reaching reform for preventing parallel punitive sanctioning and taking advantage of agency specialization would be to transfer criminal prosecution authority to agencies (leaving the criminal prosecutor with authority to prosecute general crimes only). Such a radical change in present prosecution authority would eliminate the criminal prosecutor's oversight function as well as her independence from the population regulated.

272. See supra notes $19-21,195-98$ and accompanying text. 
process challenges. ${ }^{273}$ This trend is desirable because the private version of a punitive civil sanction ${ }^{274}$ removes the burden of prosecution from the government, thereby allowing the private sector to fund law enforcement. ${ }^{275}$ A system that lets private plaintiffs secure punitive sanctions can save the government money and increase the community's total sanctioning power.

Privately sought punitive sanctions are an integral part of the middleground. In Halper and other cases, the Court has relied on the law of punitive tort damages to justify state-invoked punitive civil sanctions, thereby implicitly recognizing the similarities between state and private punitive sanctions. ${ }^{276}$ Understandably, then, many of the issues raised by state-invoked punitive civil sanctions also have implications for privately invoked punitive civil sanctions.

Even though the government may no longer seek additional punitive sanctions for conduct that it has already punished, current law does not prohibit parallel state and private punitive sanctions. ${ }^{277}$ A more rational way to organize punitive sanctioning would be to prohibit independent private suits for punitive sanctions if the state used or intended to use punitive sanctions on its own. This system would protect citizens from cumulative punishments. This proposal is even more important in view of recent case law, which indicates that some privately invoked punitive monetary sanctions are more severe than state-invoked punitive monetary sanctions. ${ }^{273}$ The tripartite structure proceeds on the idea that the severity of a sanction should guide its classification. If money sanctions disproportionate to the damage caused are punitive enough

273. Pacific Mut. Life Ins. Co. v. Haslip, 111 S. Ct. 1032 (1991) (punitive damage award more than four times amount of compensatory damages, more than 200 times out-of-pocket expense of employee-plaintiff, and larger than permissible fine under state law held constitutional under Due Process Clause, citing historic practice).

274. This development is exemplified by the RICO statute's treble damages provision. 18 U.S.C. $\$$ 1964(c) (1991). See supra notes 21, 193 and accompanying text.

275. See generally William M. Landes \& Richard A. Fosner, The Private Enforcement of Law, $4 \mathrm{~J}$. LEGAL STUD. 1 (1975) (analyzing relationship between public and private enforcement of law).

276. See supra notes $167-73$ and accompanying text.

277. United States v. Halper, 490 U.S. 435, 451 (1989) ("[N]othing . . precludes a private party from filing a civil suit seeking damages for conduct that previously was the subject of criminal prosecution and punishment. The protections of the Double Jeopardy Clause are not triggered by litigation between private parties."). Under current law, the private punitive civil penalty can be imposed before or after a criminal conviction for the same transaction. For instance, a defendant can be convicted under the criminal section of the Clayton Act, 15 U.S.C. $\$ 1$ (1988), and be subject to the treble damage suit under 15 U.S.C. $\$ 15$ (1988). Responding to the inevitable attack that this arrangement constitutes double punishment, the Eighth Circuit stated:

The provision of 15 U.S.C. $\$ 15$ for a civil suit to collect treble damages is in addition to the criminal penalties for a violation of the antitrust laws.... [The defendant] stresses what it regards as the 'punitive' aspects of the statute. The argument seems to be that because the statute punishes it is criminal, and that only the government can punish for a wrong. Both premises are faulty. . . . Laws allowing punitive or exemplary damages to an injured individual for an act which is also a crime are multitudinous. All such laws would be voided under [the defendant's] contention.

Herald Co. v. Harper, 410 F.2d 125, 130-31 (8th Cir. 1969); cj. American Soc'y of Mechanical Eng'rs, Inc. v. Hydrolevel Corp., 456 U.S. 556, 575-76 (1982) (antitrust treble damages are "designed in part to punish past violations" and also serve to deter future violations and compensate victims).

278. See, e.g., Browning-Ferris Indus. v. Kelco Disposal, Inc., 492 U.S. 257 (1989). 
to raise claims of double jeopardy when the government seeks them after securing other punitive sanctions, it is unclear why the situation should be any different when the subsequent action is brought by a private party rather than the government.

Limiting punitive sanctions to a single judgment, however, would risk suppressing private initiative because it is often uncertain whether private plaintiffs can complete their cases without government intervention. Compensatory payouts to private plaintiffs might solve this problem. The desire for the simultaneous completion of all sanctioning does not justify sacrificing the advantages of private enforcement suits; ${ }^{279}$ unity in decisionmaking requires only that the government and a private party not both invoke punitive sanctions for the same conduct. The government should control the decision of whether itself or a private party will initiate such sanctions, but it need not always assume itself the burden of enforcement. ${ }^{280}$ Finally, the interrelationship among different sanctions strongly suggests that private suits for punitive sanctions call for special procedural protections similar to those granted in stateinitiated punitive civil proceedings. Heightened protections in private suits, indeed, might even induce legislatures and courts to open the way for more such actions seeking punitive sanctions.

\section{A New Procedural Middleground?}

Present middleground jurisprudence, including Halper, has blurred normative distinctions underlying the old separation between criminal and civil procedure. In American law, the concept of due process held the state to special tests of accuracy and fairness when it sought to punish-that is, to intrude on an unconsenting individual's privacy and autonomy. The various procedural requirements established and protected a hierarchy of values. Current middleground jurisprudence, however, has weakened this special normative task of procedure.

The Boyd line of cases ${ }^{281}$ maintained important differences between procedural rules in punitive civil cases and those in strictly remedial cases. But the Supreme Court's later approaches to middleground jurisprudence moved toward a unified (civil) procedure, eliminating most distinctions between the procedures used in punitive civil cases and those used in remedial cases. As

279. See generally POSNER, supra note 186 , at 559 (considering tradeoff between public and private law enforcement); Gary S. Becker \& George J. Stigler, Law Enforcement, Malfeasance, and Compensation of Enforcers, 3 J. LEGAL STUD. 1 (1974).

280. Private involvement in punitive sanctioning can be increased beyond the present level by creating new statutory powers for private parties to get double, triple, or, as I have suggested, even more in punitive damages. A broader use of the qui tam proceeding would also help convert some areas of completely private tort law into combined state and private punitive sanctioning. Yet it would not disturb existing punitive tort law in areas in which the government had only a weak interest.

281. See supra notes $73-75,155$ and accompanying text. 
a result, individuals subject to punitive sanctions lost significant procedural protections when their cases were diverted from the criminal to the civil process. ${ }^{282}$ The expansion of state-invoked punitive civil sanctions now harms many defendants by shifting the balance of procedural advantages. ${ }^{283}$

This Article argues that the procedure followed in deciding whether to impose a sanction should be related to the function of the sanction. This proposition is based on two core norms of American constitutional due process: (1) the more severe the sanction, the more the procedure must protect against the sanctioning of the innocent, and (2) the more it must protect the accused's dignity and privacy. The logical and normative implications of these ideas are that the criminal sanction should be contingent on the use of the most stringent procedural rules and that punitive civil sanctions do not demand equally strict procedures. ${ }^{284}$ As a corollary, procedural rules for punitive civil sanctions should be more stringent than procedural rules for nonpunitive sanctions.

Congress and the Supreme Court have tended to establish due process requirements using a bipolar distinction between criminal and noncriminal cases, for they have created a middleground procedure that provides very few distinctive protections for defendants in punitive civil proceedings. ${ }^{285}$ This bipolarity, however, requires closer scrutiny as punitive civil sanctions become more severe. When one considers the function of severely punitive civil sanctions, our society's normative ideas of procedure strongly suggest that such sanctions should be accompanied by procedural rules that offer extra protection against their erroneous imposition.

This point draws strength from the historical centrality of due process in the American adversary system. Should that system allow a person to be deprived of his or her life savings and home in an administrative hearing? Should it permit a potentially bankrupting treble penalty for alleged insider trading in a civil procedural setting with minimal barriers to sanctioning? What

282. See Chamey, supra note 14; Cheh, supra note 14, at $1334-44$ (cataloging "civil remedies" as including restitution, money penalties, loss of government benefits, forfeitures, injunction, detention, and civil commitment, some of which are punitive); Clark, supra note 14, at 382 (Court has never developed jurisprudence to determine why certain sanctions should trigger constitutional protections and others should not); Arie Freiberg \& Pat O'Malley, State Intervention and the Civil Offense, 18 LAW \& SOC'Y REV. 373, 378 (1984) (society exerts heavy pressure to allocate fewer rights and weaken due process protection in civil proceedings); Jahncke, supra note 14, at 142-47 (Eighth Amendment should apply to civil penalties); Wheeler, supra note 198; Note, supra note 62, at 1298 (in spite of its civil label, RICO is punitive in purpose and effect); Jay A. Rosenberg, Note, Constitutional Fights and Civil Forfeiture Actions, 88 CoLUM. L. REV. 390 (1988) (defendants in civil forfeitures should have right to immunity and counsel).

283. Cf. Abraham S. Goldstein, The State and the Accused: Balance of Advantage in Criminal Procedure, 69 YALE L.J. 1149, 1180-82 (1960) (reductions in criminal procedures shift balance of advantage in criminal cases toward prosecution).

284. The current substantive structure of the criminal law lends itself to creating a two-tiered or slidingscale system of criminal procedural standards. For less serious or petty criminal cases, less stringent procedural rules apply; for more serious cases, the full panoply of due process rules apply. See Felix Frankfurter \& Thomas G. Corcoran, Petty Federal Offenses and the Constitutional Guaranty of Trial by Jury, 39 HARV. L. REV. 917, 927 (1926) (during American colonial period, procedure for petty offenses expressed "desire for a swift and convenient remedy").

285. See supra Part II.D. 
about the forfeiture of a person's home for growing marijuana in the backyard? As the availability of civil monetary sanctions increases, so does the possibility that the application of such a sanction will deeply affect the life of a person or corporation. American constitutional law's vision of due process strongly suggests the need for an independent mix of procedural rules for middleground jurisprudence. ${ }^{286}$

\section{CONCLUSION}

Two paradigms, criminal and civil law, have long dominated the American law of sanctions. Judges and lawmakers have used these terms to represent sharp and well-defined differences in the nature of the legal process used to redress wrongs. But between these two paradigms there has always been a middleground in which legislatures and courts sought punitive ends through nominally civil proceedings. The history of middleground jurisprudence demonstrates the inadequacy of the bipolar paradigms for governing actual sanctioning policy. While the legal community has always recognized that many sanctions do not fit into either paradigm, it has never developed a systematic jurisprudence to explain the substantive and procedural position of punitive civil sanctions within the field of sanctioning.

Since at least the early nineteenth century, Congress has granted federal administrative agencies the power to impose punitive sanctions in civil procedural settings, first through the initiation of lawsuits in courts and later through purely administrative assessment. As the federal bureaucracy has grown, the power to impose punitive civil sanctions has been extended to more executive offices and independent agencies. At the same time, punitive sanctions have become more severe: what were once penalties of hundreds of dollars are now penalties of hundreds of thousands of dollars.

In Halper, the Court suggested that there is neither any limit on the permissible punitiveness of monetary civil sanctions, nor any special procedural requirements for the imposition of such sanctions. The Court may have intended to sever the relationship between the severity of civil sanctions and procedural protections in civil law, which can only worry those who seek to protect due process values. This procedural erosion calls for the resurrection and extension of a middleground that connects procedural rights with the severity of sanctions.

286. If one accepts the proposition that some special due process protections should be required in some cases but not others, the question remains: what constitutes a sufficiently punitive case to warrant the use of special protections? This question asks the courts to assess a sanction's severity in order to determine procedural rights. It is similar to the question addressed by the courts in determining when a minor criminal case becomes a case that is granted the full range of criminal due process protection. It corresponds to the analytic problem of assessing whether sanctions are remedial or punitive. It also resembles the measurements of severity made in developing sentencing guidelines and making sentencing decisions. Finally, it has analogies to the judicial assessments of dangerousness in detention hearings. 
But the existing framework of punitive civil monetary sanctions must be criticized not only for the inadequate procedural protections it provides for defendants, but also for the inadequate severity of the sanctions allowed. Lawmakers may have resisted increasing the size of money sanctions when they expected that citizens would be protected only by run-of-the-mill procedures. An appropriate procedural setting, however, would permit substantial growth in the size and effectiveness of money sanctions. This development should also correct the currently excessive reach of the criminal law, while concurrently reducing the proportion of cases that escape punitive sanctions altogether because a criminal sanction is inappropriate and a middleground solution is unavailable.

However, a tripartite law of sanctions, with a large middleground of punitive civil sanctions, carries the potential for two serious problems. First, if offenders will be punished where previously they would have been liable only for compensation, we may be creating a draconian regime. The development of appropriate procedural protections should help protect against this evil, but the very existence of a broad range of highly punitive civil sanctions may create dangers that procedural rules can only soften. Protection against overextension must be a primary concern of those who cultivate the middleground.

Second, punitive civil sanctions might carry a socioeconomic bias. By their very nature, punitive civil money sanctions are effective only against those who can pay. Such sanctions therefore will focus on crimes characteristic of the middle and upper classes-typically crimes of fraud, embezzlement, theft by deceit, violation of trust, and drug offenses, along with the whole range of offenses committed by corporations. An enhanced regime of punitive civil sanctions will not be effective against poor people who commit crimes; while the middleground sanctions should help to keep some people out of prison, those who cannot pay will go to prison. This would only exacerbate the existing inequality. ${ }^{287}$ Scaling money sanctions to financial resources, so that the sanctions impose roughly equivalent burdens on populations of varying wealth, may somewhat limit this problem. Yet there will always be a bankrupt population for whom the only answer is imprisonment. The need to preserve equality of treatment may thus require the imprisonment of rich people too, even when money sanctions against them would otherwise suffice. ${ }^{288}$ This solution would not contradict any of the basic tenets of the middleground, for I have not argued that punitive civil money sanctions should replace prison in every instance in which the defendant can pay. Indeed, society's basic retributive needs will

287. Privately invoked punitive civil sanctions might counteract this disparity. Actions generating such sanctions will predominantly target the wealthy segment of the population. Thus, the creation of such middleground sanctions might actually disfavor the rich by encouraging suits against them.

288. See Fletcher, supra note 38, at 924 ("If killers and rapists were allowed simply to pay off those victims (and families) who apprehended and sued them, the rich would enjoy an intolerable privilege to force the sale of lives and human dignity."). 
always call for the use of demonstrative public sanctions such as imprisonment against at least some offenders. 
